\title{
Shorter Contributions to Paleontology and Stratigraphy
}

\section{U.S. GEOLOGICAL SURVEY BULLETIN 1934}

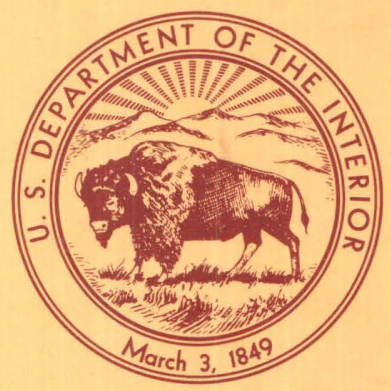




\section{SELECTED SERIES OF U.S. GEOLOGICAL SURVEY PUBLICATIONS}

\section{Periodicals}

Earthquakes \& Volcanoes (issued bimonthly).

Preliminary Determination of Epicenters (issued monthly).

\section{Technical Books and Reports}

Professional Papers are mainly comprehensive scientific reports of wide and lasting interest and importance to professional scientists and engineers. Included are reports on the results of resource studies and of topographic, hydrologic, and geologic investigations. They also include collections of related papers addressing different aspects of a single scientific topic.

Bulletins contain significant data and interpretations that are of lasting scientific interest but are generally more limited in scope or geographic coverage than Professional Papers. They include the results of resource studies and of geologic and topographic investigations, as well as collections of short papers related to a specific topic.

Water-Supply Papers are comprehensive reports that present significant interpretive results of hydrologic investigations of wide interest to professional geologists, hydrologists, and engineers. The series covers investigations in all phases of hydrology, including hydrogeology, availability of water, quality of water, and use of water.

Circulars present administrative information or important scientific information of wide popular interest in a format designed for distribution at no cost to the public. Information is usually of short-term interest.

Water-Resources Investigations Reports are papers of an interpretive nature made available to the public outside the formal USGS publications series. Copies are reproduced on request unlike formal USGS publications, and they are also available for public inspection at depositories indicated in USGS catalogs.

Open-File Reports include unpublished manuscript reports, maps, and other material that are made available for public consultation at depositories. They are a nonpermanent form of publication that may be cited in other publications as sources of information.

\section{Maps}

Geologic Quadrangle Maps are multicolor geologic maps on topographic bases in 7.5- or 15-minute quadrangle formats (scales mainly $1: 24,000$ or $1: 62,500$ ) showing bedrock, surficial, or engineering geology. Maps generally include brief texts; some maps include structure and columnar sections only:

Geophysical Investigations Maps are on topographic or planimetric bases at various scales; they show results of surveys using geophysical techniques, such as gravity, magnetic, seismic, or radioactivity, which reflect subsurface structures that are of economic or geologic significance. Many maps include correlations with the geology.

Miscellaneous Investigations Series Maps are on planimetric or topographic bases of regular and irregular areas at various scales; they present a wide variety of format and subject matter. The series also includes 7.5-minute quadrangle photogeologic maps on planimetric bases that show geology as interpreted from aerial photographs. Series also includes maps of Mars and the Moon.
Coal Investigations Maps are geologic maps on topographic or planimetric bases at various scales showing bedrock or surficial geology, stratigraphy, and structural relations in certain coal-resource areas.

Oil and Gas Investigations Charts show stratigraphic information for certain oil and gas fields and other areas having petroleum potential.

Miscellaneous Field Studies Maps are multicolor or blackand-white maps on topographic or planimetric bases on quadrangle or irregular areas at various scales. Pre-1971 maps show bedrock geology in relation to specific mining or mineral-deposit problems; post-1971 maps are primarily black-and-white maps on various subjects such as environmental studies or wilderness mineral investigations.

Hydrologic Investigations Atlases are multicolored or blackand-white maps on topographic or planimetric bases presenting a wide range of geohydrologic data of both regular and irregular areas; principal scale is $1: 24,000$, and regional studies are at $1: 250,000$ scale or smaller.

\section{Catalogs}

Permanent catalogs, as well as some others, giving comprehensive listings of U.S. Geological Survey publications are available under the conditions indicated below from the U.S. Geological Survey, Books and Open-File Reports Section, Federal Center, Box 25425, Denver, CO 80225. (See latest Price and Availability List.)

"Publications of the Geological Survey, 1879-1961" may be purchased by mail and over the counter in paperback book form and as a set of microfiche.

"Publications of the Geological Survey, 1962-1970" may be purchased by mail and over the counter in paperback book form and as a set of microfiche.

"Publications of the U.S. Geological Survey, 1971-1981" may be purchased by mail and over the counter in paperback book form (two volumes, publications listing and index) and as a set of microfiche.

Supplements for 1982, 1983, 1984, 1985, 1986, and for subsequent years since the last permanent catalog may be purchased by mail and over the counter in paperback book form.

State catalogs, "List of U.S. Geological Survey Geologic and Water-Supply Reports and Maps For (State)," may be purchased by mail and over the counter in paperback booklet form only.

"Price and Availability List of U.S. Geological Survey Publications," issued annually, is available free of charge in paperback booklet form only.

Selected copies of a monthly catalog "New Publications of the U.S. Geological Survey" are available free of charge by mail or may be obtained over the counter in paperback booklet form only. Those wishing a free subscription to the monthly catalog "New Publications of the U.S. Geological Survey" should write to the U.S. Geological Survey, 582 National Center, Reston, VA 22092.

Note.-Prices of Government publications listed in older catalogs, announcements, and publications may be incorrect. Therefore, the prices charged may differ from the prices in catalogs, announcements, and publications. 


\section{Shorter Contributions to Paleontology and Stratigraphy}

Edited by WILLIAM J. SANDO

This volume is published as chapters A-E. These chapters are not available separately. Chapter titles are listed in the volume table of contents. 


\section{U.S. DEPARTMENT OF THE INTERIOR \\ MANUEL LUJAN, Jr., Secretary \\ U.S. GEOLOGICAL SURVEY \\ Dallas L. Peck, Director}

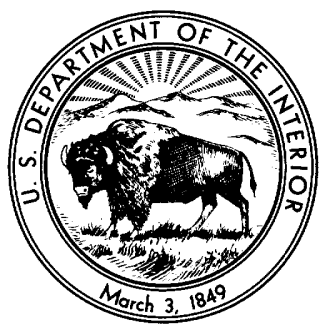

Any use of trade, product, or firm names in this publication is for descriptive purposes only and does not imply endorsement by the U.S. Government

For sale by the

Books and Open-File Reports Section

U.S. Geological Survey

Federal Center, Box 25425

Denver, CO 80225

\section{Library of Congress Cataloging in Publication Data}

Shorter contributions to paleontology and stratigraphy / edited by William J.

$$
\text { Sando }
$$

p. $\quad$ cm. - (U.S. Geological Survey bulletin ; $1934 \mathrm{~A}-\mathrm{E})$

Includes bibliographical references.

Supt. of Docs. no.: I 19.3:1934A-E

1. Ammonoidea-West (U.S.) 2. Paleontology-West (U.S.) 3. Paleontology-Cretaceous. 4. Paleontology-Pennsylvania-Bucks County. 5. Paleontology-Ordovician. 6. Paleontology-CaliforniaSanta Cruz Mountains. I. Sando, William Jasper. II. Series.

QE75.B9 no. 1934 A-E

[QE807.A5] 


\section{CONTENTS}

[Letters designate the chapters]

(A) A Giant Scaphite from the Turonian (Upper Cretaceous) of the Western Interior of the United States, by William A. Cobban and W. James Kennedy

(B) Evolution and Biogeography of the Cenomanian (Upper Cretaceous) Ammonite Metoicoceras Hyatt, 1903, with a Revision of Metoicoceras praecox Haas, 1949, by William A. Cobban and W. James Kennedy

(C) Baculites thomi Reeside, 1927, an Upper Cretaceous Ammonite in the Western Interior of the United States, by William A. Cobban and W. James Kennedy

(D) Discovery of Early Ordovician Fossils in Bucks County, Pennsylvania, by John E. Repetski and Avery Ala Drake, Jr.

(E) An Unusual Late Cretaceous Fauna from an Oyster-Rich Interval in the Santa Cruz Mountains of California, by William P. Elder 

Chapter A

\section{A Giant Scaphite from the Turonian (Upper Cretaceous) of the Western Interior of the United States}

\section{By WILLIAM A. COBBAN and W. JAMES KENNEDY}

Description and illustrations of a new species from the Carlile Shale of South Dakota 



\section{CONTENTS}

Abstract A1

Introduction A1

Systematic Paleontology A1

Family SCAPHITIDAE Gill A1

Subfamily SCAPHITINAE Gill A1

Genus SCAPHITES Parkinson A1

References $\mathbf{A 2}$

Scaphites borealis n.sp. A1

PLATE

[Plate follows references cited]

1. Scaphites borealis $\mathrm{n} . \mathrm{sp}$. 



\title{
A Giant Scaphite from the Turonian (Upper Cretaceous) of the Western Interior of the United States
}

\author{
By William A. Cobban ${ }^{1}$ and W. James Kennedy ${ }^{2}$
}

\begin{abstract}
A new giant species of scaphite, Scaphites borealis, is described from the upper Turonian Scaphites whitfieldi zone of the Carlile Shale of South Dakota. The ornament of the new species is comparable in style to that of co-occurring $S$. whitfieldi Cobban, 1952, but its shell volume is 17 times greater than the largest macroconch of S. Whitfieldi Cobban, of which it is believed to be a hypermorphic giant derivative.
\end{abstract}

\section{INTRODUCTION}

Heteromorph ammonites of the Family Scaphitidae are important stratigraphic indicators in Turonian rocks of the Western Interior of the United States and Canada. The fauna was monographed by Cobban (1952), and some additional taxa were described by Crick $(1978,1979)$ and Cobban (1983). Landman (1987) provided a recent review of several of the Turonian species. We describe below a remarkable new giant species, herein named Scaphites borealis, from the upper Turonian Scaphites whitfieldi zone of Butte County, South Dakota. The general style of ornament of the new species, marked by nontuberculate, crowded, narrow ribs on the phragmocone and body chamber, is the same as that of co-occurring Scaphites whitfieldi Cobban, 1952. But, whereas the latter species has adult macroconchs that never exceed $50 \mathrm{~mm}$ in length, the holotype of $S$. borealis is a macroconch $130 \mathrm{~mm}$ long, a size exceeded among scaphitids only by the Jeletzkytes, Rhaeboceras, and Acanthoscaphites of the Campanian and Maastrichtian. Because of the co-occurrence and comparable ornament of $S$. whitfieldi and $S$. borealis, we believe that the former, which is part of a long-ranging Western Interior lineage, gave rise to the latter. Whereas other

\footnotetext{
Manuscript approved for publication February 27, 1990.

${ }^{1}$ U.S. Geological Survey, Denver, CO 80225

${ }^{2}$ Geological Collections, University Museum, Parks Road, University of Oxford, Oxford OX1 3PW, U.K.
}

Scaphites show progressive size increase and decrease within lineages (Cobban, 1952, fig. 2), the evolution of $S$. borealis involved a sudden jump and a seventeenfold volume increase. The new species is presumably a hypermorphic giant (McNamara, 1986) in which the delayed onset of the maturity and development of the uncoiled body chamber allowed prolonged growth.

The holotype and paratypes are at the Black Hills Institute of Geological Research, Hill City, S. Dak. We thank N.L. Larson and P.L. Larson of the Institute for providing these specimens for our study. Kennedy acknowledges the financial support of the Natural Environment Research Council (U.K.), the Royal Society, and the Astor Fund (Oxford) and the technical assistance of the staff of the Geological Collections, Oxford University Museum, and the Department of Earth Sciences, Oxford, U.K.

\section{SYSTEMATIC PALEONTOLOGY}

Family SCAPHITIDAE Gill, 1871

Subfamily SCAPHITINAE Gill, 1871

Genus SCAPHITES Parkinson, 1811

Type species. - Scaphites equalis J. Sowerby, 1813. Scaphites borealis n.sp.

Plate 1

1952. Scaphites whitfieldi Cobban, p. 24 (pars), pl. 5, fig. 1 only.

Derivation of name. - Boreas, the Greek word for the north wind, in reference to the northerly occurrence of the species.

Types.-Holotype is BHI (Black Hills Institute of Geological Research) 1962; paratypes are BHI 1963 and BHI 1964. All are from the upper Turonian Scaphites whitfieldi zone in the Turner Sandy Member of the Carlile Shale on the western side of Belle Fourche Reservoir in Butte County, South Dakota. Other specimens are represented by the following plaster casts at the National 
Museum of Natural History (USNM), Washington, D.C.: USNM 420321, collected by M.J. Evetts from $32.6 \mathrm{~m}$ above the base of the Turner Sandy Member of the Carlile Shale, Wild Cat Creek, in the NE $1 / 4$ sec. 8, T. 9 N., R. 3 E., Butte County, South Dakota; and USNM 420320, collected by P.S. Warren from the Morden Shale, Vermilion River, southern Manitoba, Canada. USNM 106738a is Cobban's (1952, pl. 5, fig. 1) original from a ferruginous concretion about $78 \mathrm{~m}$ above the base of the Carlile Shale $9.6 \mathrm{~km}$ north of Belle Fourche in the N1/2 sec. 10, T. 9 N., R. 2 E., Butte County, South Dakota.

Description.-The holotype (pl. 1, fig. 4) is a macroconch $130 \mathrm{~mm}$ long, preserved in a ferruginous concretion. The phragmocone is crushed, but the body chamber is partially preserved in relief. Traces of the original nacreous shell are present. The very involute septate coil has an estimated diameter of $88 \mathrm{~mm}$. Distant, narrow, sharp primary ribs arise on the umbilical wall. These ribs are straight and slightly prorsiradiate on the flank and divide into two or three secondary ribs on the outer flank, where shorter intercalated ribs are inserted; all pass straight across the venter without interruption.

The shaft is straight and exhibits a slight bulge that partially occludes the umbilicus of the spire; the final hook is well detached from the spire. The body chamber occupies all of the hook and shaft. The mature aperture is marked by a flare preceded by a prominent annular constriction. Primary ribs number 28 on the body chamber. The ribs arise on the dorsal wall, where they are weak and feebly concave, and sweep forward over the dorsolateral shoulder; ribs become progressively more prorsiradiate toward the aperture of the shell. Ribs are low and distant on the shaft and straight to feebly convex on the flank and split into two or three weak secondaries at the juncture of the outer flank with the ventrolateral shoulder. Secondaries, plus occasional intercalatories, are weak and pass straight across the venter. Ribbing crowds and becomes relatively stronger on the hook, and the secondaries become quite sharp. Primary ribs bifurcate once they are on the inner flank and a second time on the outer flank in some cases. About 75 ribs cross the venter of the body chamber.

Paratype BHI 1963 is a nearly complete adult 119 $\mathrm{mm}$ long. Because the umbilicus and dorsolateral area of the shaft are missing, it is not possible to assign the specimen to either macroconch or microconch with any certainty. The specimen shows all the features of ornament of the holotype to advantage, and the ventral decoration is well seen (pl. 1, figs. 1-3).

What we take to be the microconch of the species is represented by casts USNM 420320 and 420321 . The latter shows the umbilicus not occluded by the shaft and has a slender body chamber and quite sharp ribbing. Its original length is estimated at $110 \mathrm{~mm}$. The suture is only imperfectly visible but shows the lobes to have plump, subphylloid folioles, as they do in $S$. whitfieldi.
Discussion. - The fragment figured by Cobban (1952, pl. 5, fig. 1) as a very large Scaphites whitfieldi is certainly a part of a body chamber of the present species. Large size alone separates $S$. borealis from all other Turonian Scaphites, and we know of no other contemporary or near-contemporary species with which it is likely to be confused.

Occurrence. - The few specimens from the Western Interior of the United States are from the northeastern flank of the Black Hills uplift in western South Dakota. The Turner Sandy Member of the Carlile Shale, which yielded these specimens, crops out extensively along all the flanks of the Black Hills. Scaphites whitfieldi has been found all around the Black Hills as well as at many localities in Montana, Wyoming, Colorado, Utah, and New Mexico. The presence of $S$. borealis in the $S$. whitfieldi zone in only one small area on the northeastern flank of the Black Hills suggests a northeastern source for the species, a theory that is further supported by the occurrence of $S$. borealis in Manitoba, Canada. A plaster cast (USNM 420320) of a crushed adult $116 \mathrm{~mm}$ in length from the Morden Shale of the Vermilion River area is in the National Museum of Natural History in Washington, D.C. The original specimen was submitted by S.R. Kirk in 1932 to J.B. Reeside, Jr., for identification. The whereabouts of the specimen is now unknown.

\section{REFERENCES CITED}

Cobban, W.A., 1952, Scaphitoid cephalopods of the Colorado group: U.S. Geological Survey Professional Paper 239, 42 p., 21 pls. (1951 imprint).

1983, Molluscan fossil record from the northeastern part of the Upper Cretaceous seaway, Western Interior: U.S. Geological Survey Professional Paper 1253-A, p. A1-A25, 15 pls.

Crick, R.E., 1978, Morphological variations in the ammonite Scaphites of the Blue Hill Member, Carlile Shale, Upper Cretaceous, Kansas: University of Kansas Paleontological Contributions Paper 88, 27 p., 2 pls.

1979, A pteroscaphitid (Cephalopoda, Ammonoidea) from the Upper Cretaceous (Turonian) of Kansas: Journal of Paleontology, v. 53, no. 1, p. 98-102.

Gill, T., 1871, Arrangement of the families of mollusks: Smithsonian Miscellaneous Collections 227, $49 \mathrm{p}$.

Landman, N.H., 1987, Ontogeny of Upper Cretaceous (TuronianSantonian) scaphitid ammonites from the Western Interior of North America; systematics, developmental patterns, and life history: Bulletin of the American Museum of Natural History, v. 85 , art. 2, p. 117-241.

McNamara, K.J., 1986, A guide to the nomenclature of heterochrony: Journal of Paleontology, v. 60, no. 1, p. 4-13.

Parkinson, J., 1811, Organic remains of a former world: London, Robson, v. 3, 479 p., 22 pls.

Sowerby, J., 1813, The mineral conchology of Great Britain: London, Meredith, v. 1, p. 33-96, pls. 10-44. 


\section{PLATE 1}

Contact photographs of the plate in this report are available, at cost, from the

U.S. Geological Survey Photographic Library, Federal Center, Denver, CO 80225. 


\section{PLATE 1}

\section{Scaphites borealis n.sp.}

[All figures natural size]

Figures 1-4. From the Turner Sandy Member of the Carlile Shale on the western side of Belle Fourche Reservoir, Butte County, South Dakota.

1-3. Bottom, side, and top views of paratype BHI 1963.

4. Side view of holotype BHI 1962. 


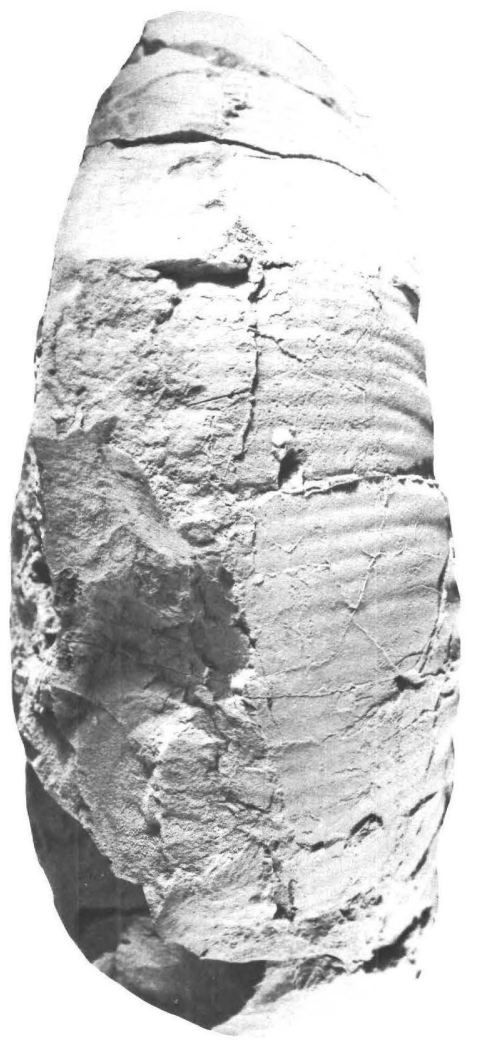

1

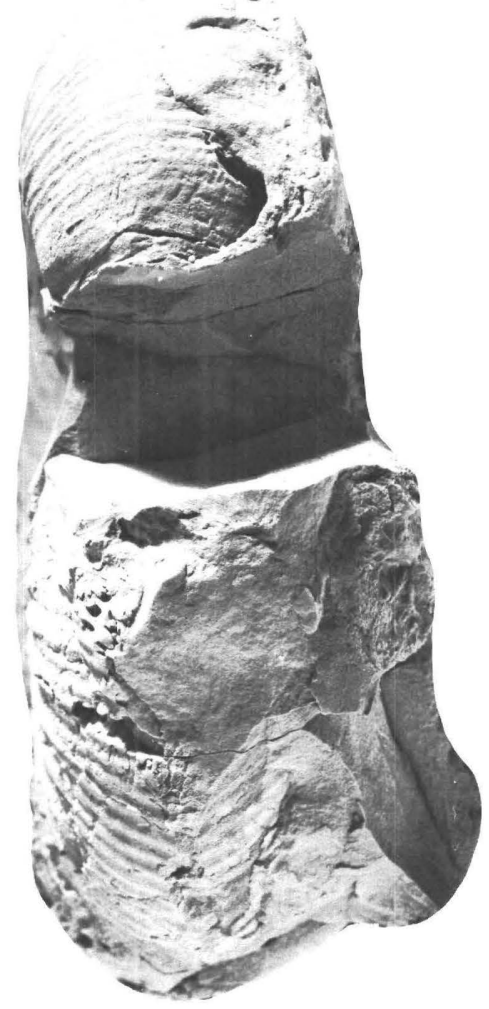

3
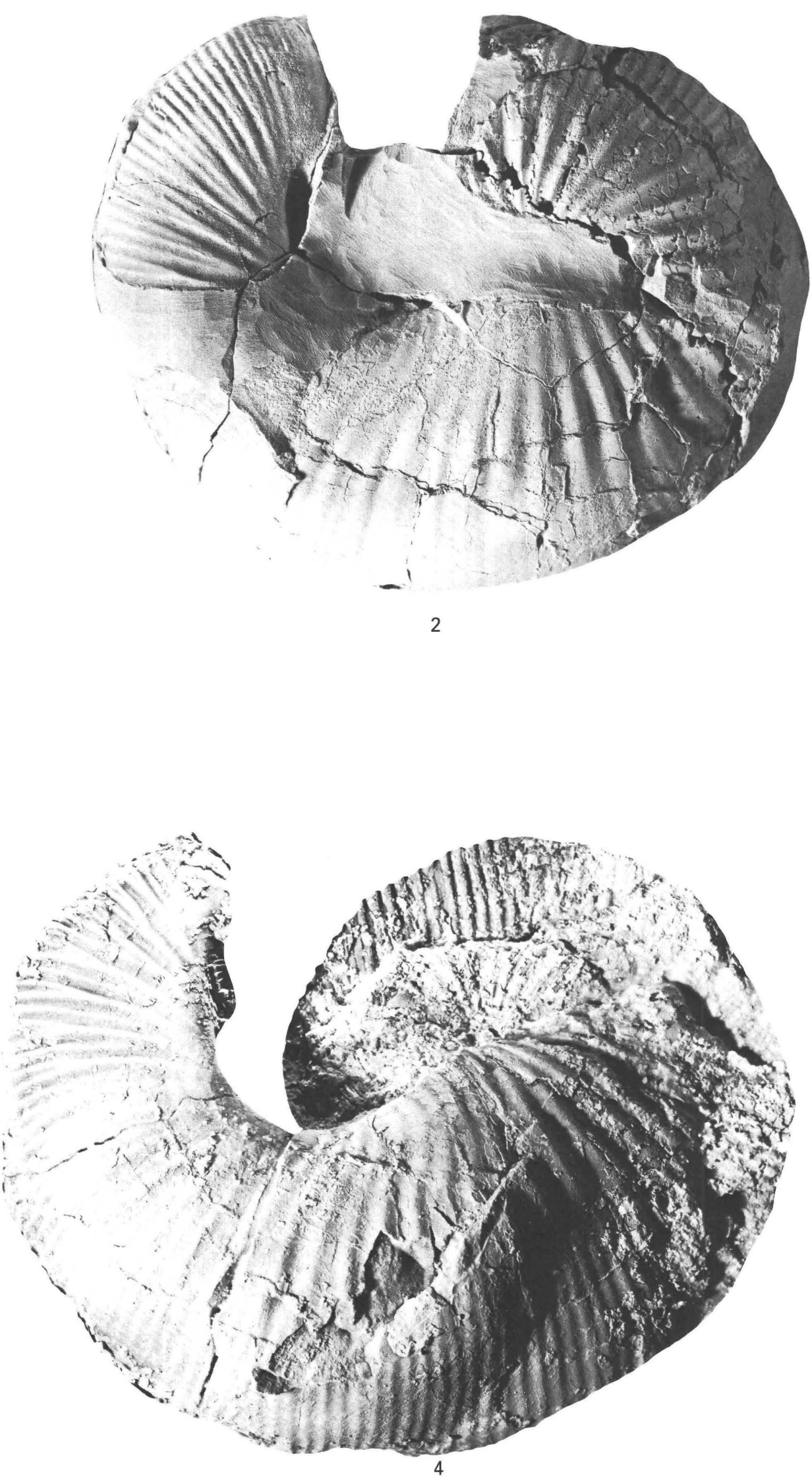

SCAPHITES BOREALIS 

Chapter B

Evolution and Biogeography of the Cenomanian (Upper Cretaceous) Ammonite Metoicoceras Hyatt, 1903, with a Revision of Metoicoceras praecox Haas, 1949

By WILLIAM A. COBBAN and W. JAMES KENNEDY

Descriptions and illustrations of an important lineage of ammonites from Texas and the Western Interior of the United States

U.S. GEOLOGICAL SURVEY BULLETIN 1934

SHORTER CONTRIBUTIONS TO PALEONTOLOGY AND STRATIGRAPHY 



\title{
CONTENTS
}

\author{
Abstract B1 \\ Introduction $\mathbf{B 1}$ \\ Conventions B1
}

Repositories of Specimens B1

Suture Terminology B2

Systematic Paleontology B2

Order AMMONOIDEA Zittel, $1884 \quad$ B2

Suborder AMMONITINA Hyatt, 1889 B2

Superfamily ACANTHOCERATACEAE de Grossouvre, $1894 \quad$ B2

Family ACANTHOCERATIDAE de Grossouvre, 1894 B2

Genus METOICOCERAS Hyatt, 1903 B2

Metoicoceras praecox Haas B2

Sequence of Metoicoceras in the Western Interior B4

Origin of Metoicoceras $\mathbf{B 8}$

References Cited B10

\section{PLATES}

[Plates follow references cited]

1-3. Metoicoceras praecox Haas

4. Metoicoceras sp. A and Metoicoceras mosbyense Cobban

5. Metoicoceras mosbyense Cobban, Metoicoceras aff. praecox Haas, Metoicoceras swallovi (Shumard), and Metoicoceras latoventer Stephenson

6. Metoicoceras geslinianum (d'Orbigny), Metoicoceras frontierense Cobban, and Metoicoceras aff. frontierense Cobban

\section{FIGURES}

1. Chart showing sequence of Metoicoceras species in the Western Interior and northern Texas and their placement in part of the Cenomanian ammonite zones of the Western Interior B2

2, 3. Drawings showing:

2. External sutures of Metoicoceras B5

3. Costal whorl sections of various species of Metoicoceras B6

\section{TABLE}

1. Dimensions and ratios of Metoicoceras praecox Haas from U.S. Geological Survey Mesozoic locality $21850 \quad$ B4 



\title{
Evolution and Biogeography of the Cenomanian (Upper Cretaceous) Ammonite Metoicoceras Hyatt, 1903, With a Revision of Metoicoceras praecox Haas, 1949
}

\author{
By William A. Cobban ${ }^{1}$ and W. James Kennedy ${ }^{2}$
}

\begin{abstract}
Metoicoceras is an important genus, especially in the Western Interior of the United States. Five chronologic species can be recognized in Wyoming (from oldest to youngest): $M$. sp. A, $M$. praecox Haas, $M$. frontierense Cobban, $M$. mosbyense Cobban, and $M$. geslinianum (d'Orbigny). Metoicoceras praecox, which is described in detail, has several features in common with $M$. latoventer Stephenson, a middle Cenomanian species known from the Gulf Coast region. The origin of Metoicoceras probably lies in some contemporary acanthoceratid ammonite such as Plesiacanthoceras, which occurs with the earliest Metoicoceras in Texas, and involved sutural simplification and profound modification of adult ornament. Early members of the lineage are known from a limited area in Texas, but, during the early part of the late Cenomanian, members of the genus spread throughout the Western Interior. The latest species, $M$. geslinianum (d'Orbigny), migrated out beyond the Western Interior during the late Cenomanian Sciponoceras gracile zone and became an important international guide fossil known from the Western Interior and Gulf Coast region, Mexico, Brazil, Africa, western Europe, Israel, Iran, and the U.S.S.R.
\end{abstract}

\section{INTRODUCTION}

The genus Metoicoceras Hyatt, 1903 (type species Ammonites swallovi Shumard, 1860), is an involute, compressed, and generally ribbed ammonite of medium size that is an important fossil of the middle and late Cenomanian faunas in the Western Interior of the United States. A succession of species that is of great stratigraphic value is recognized (text fig. 1). Most of these species are endemic

\footnotetext{
Manuscript approved for publication February 27, 1990.

${ }^{1}$ U.S. Geological Survey, Denver, CO 80225.

${ }^{2}$ Geological Collections, University Museum, Parks Road, University of Oxford, Oxford OX1 3PW, U.K.
}

to the Western Interior, but, near the close of Cenomanian time, the final species, $M$. geslinianum (d'Orbigny), spread out beyond the region and is known from Texas, Mexico, Brazil, Africa, western Europe, Israel, Iran, and the U.S.S.R. Metoicoceras geslinianum is a valuable guide fossil for international correlation of late Cenomanian rocks.

One of the oldest species of Metoicoceras, M. praecox Haas, 1949, is widely distributed in the Western Interior but is a little known form. We describe herein the ontogeny and variation of this species on the basis of a large collection of topotypes from the basal part of the Cody Shale of Big Horn County, Wyoming. This description provides the basis for our discussion of the evolution and biogeography of the genus.

The large collection of topotypes was gathered by J.B. Reeside, Jr., and D.A. Andrews of the U.S. Geological Survey (USGS) in 1938 and by the late W.D. Greene of Greybull, Wyo. Some topotypes were also supplied by N.H. James of Greybull. All topotypes have been assigned USGS Mesozoic locality number 21850.

The specimens described in this report are in the National Museum of Natural History (USNM) in Washington, D.C., and have USNM catalog numbers. All photographs were made by Robert E. Burkholder (USGS). The drawings of sutures and whorl sections were made by Cobban. Kennedy acknowledges the financial support of the Natural Environment Research Council (U.K.), the Royal Society, and the Astor Fund (Oxford, U.K.).

\section{CONVENTIONS}

\section{Repositories of Specimens}

The following abbreviations are used to indicate the repositories of specimens cited in the text: USNM, National 


\begin{tabular}{|c|c|c|c|c|}
\hline \multicolumn{2}{|c|}{ STAGE } & ZONE & WESTERN INTERIOR & NORTH TEXAS \\
\hline \multirow{5}{*}{ 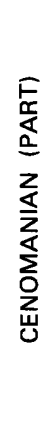 } & \multirow{4}{*}{ 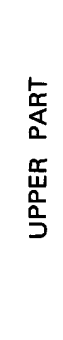 } & Sciponoceras gracile & \multirow{5}{*}{$\begin{array}{l}\text { M. mosbyense } \\
\text { M. frontierense } \\
\text { M. praecox } \\
\text { M. sp. A }\end{array}$} & \multirow[t]{4}{*}{ M. geslinianum } \\
\hline & & Metoicoceras mosbyense & & \\
\hline & & Dunveganoceras problematicum & & \\
\hline & & Dunveganoceras pondi & & \\
\hline & 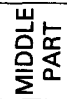 & Plesiacanthoceras wyomingense & & $\begin{array}{l}\text { M. swallovi } \\
\text { M. latoventer } \\
\text { M. crassicostae }\end{array}$ \\
\hline
\end{tabular}

Figure 1. Sequence of Metoicoceras species in the Western Interior and northern Texas and their placement in part of the Cenomanian ammonite zones of the Western Interior.

Museum of Natural History, Washington, D.C.; AMNH, American Museum of Natural History, New York, N.Y.; UMIP, University of Minnesota Invertebrate Paleontology collections, Minneapolis, Minn.

\section{Suture Terminology}

The system of Wedekind (1916) as propounded by Kullmann and Wiedmann (1970) is followed, where $\mathrm{E}$ is the external lobe, $\mathrm{L}$ is the lateral lobe, and $\mathrm{U}$ is the umbilical lobe.

\section{SYSTEMATIC PALEONTOLOGY}

Order AMMONOIDEA Zittel, 1884

Suborder AMMONITINA Hyatt, 1889

Superfamily ACANTHOCERATACEAE de Grossouvre, 1894

Family ACANTHOCERATIDAE de Grossouvre, 1894

Genus METOICOCERAS Hyatt, 1903

Type species. - Ammonites swallovi Shumard, 1860, p. 591 , by subsequent designation of Shimer and Shrock (1944, p. 591).

Diagnosis. - This genus includes moderately involute ammonites that have compressed whorls and ornament of primary and secondary ribs, umbilical bullae, inner and outer ventrolateral tubercles, and (in the early species) weak siphonal tubercles on the innermost whorls. The venter on the inner whorls is flattened and bordered by the outer ventrolateral tubercles, whereas the venter on the body chamber is usually rounded, at least near the aperture. Ribs are straight to slightly flexuous; they may flatten on the outer part of the flanks or on the ventrolateral shoulder. Inner ventrolateral tubercles usually weaken and disappear near the end of the phragmocone. The suture is quite simple, displaying little-divided saddles and a rectangular bifid lateral lobe that is narrower than the first lateral saddle.

\section{Metoicoceras praecox Haas}

Plates 1-3; text figures $2 B-D, 3 C, 3 E$

1949. Metoicoceras whitei Hyatt praecox Haas, p. 15, pls. 5-7, text figs. 5-9.

1952. Metoicoceras praecox Haas. Cobban and Reeside, p. 1017.

1970. Metoicoceras praecox Haas. Ilyin, fig. 2e.

1977. Metoicoceras cf. M. praecox Haas. Cobban, p. 25, pl. 16, fig. $25 ;$ pl. 21, figs. $8,9$.

1981. Metoicoceras praecox Haas. Kennedy and others, p. 58.

Types.-Holotype AMNH 26415, from the upper

Cenomanian zone of Dunveganoceras pondi in the basal part of the Cody Shale northeast of Greybull, Big Horn County, Wyoming. Hypotypes USNM 427905 through 427937 , from the same locality as the holotype and paratypes at USGS Mesozoic locality 21850 in the SE1/4 sec. 9, T. 53 N., R. 92 W.

Material.-About 60 topotypes from USGS Mesozoic locality 21850 were available for study, as were a few specimens from other localities in the Western Interior. The specimens from locality 21850 are mostly uncrushed internal molds from calcareous sandstone concretions. Body chambers are infilled by indurated, very fine grained sandstone, and phragmocones are calcite filled. Ornament and sutures are well preserved.

Description. - The holotype (Haas, 1949, pl. 5, figs. $1,5,8)$ is most of an adult body chamber that partly encloses some of the septate coil. The whorl height at the larger end of the body chamber is $50 \mathrm{~mm}$. Diameter of the body chamber is estimated at $116 \mathrm{~mm}$, and the umbilical ratio is estimated at 0.23 . Whorls are much higher than they are wide and have somewhat flattened flanks and a wellrounded venter. The umbilicus is shallow amd has a gently sloping wall. Ornament on the inner whorls consists of 
rather widely spaced primary ribs that arise in pairs from umbilical bullae; secondary ribs arise farther out on the flank. All ribs on the inner whorls bear a row of ventrolateral tubercles. According to Haas (1949, p. 16), these ribs number 24 per whorl. Ornament on the preserved part of the body chamber consists of fairly widely spaced, rectiradiate, foldlike ribs that cross the venter transversely; there are no umbilical or ventrolateral tubercles.

Several topotype specimens from locality 21850 ranging from 20 to $35 \mathrm{~mm}$ in diameter reveal details in ornament that Haas did not record in his collection of the holotype and five paratypes. Haas mentioned the presence of a row of clavate ventrolateral tubercles on the small whorls but did not note the presence of siphonal tubercles. All our topotypes from 25 to $35 \mathrm{~mm}$ in diameter (seven specimens: USNM 427905-427909, 427938, 427939) have weak siphonal clavi at some diameter (see pl. 1, figs. 3-7, for 427905 and 427906). These clavi weaken and disappear at diameters (rounded) of about 24, 28, 30, 31, 32, and 34 $\mathrm{mm}$ on these specimens. Siphonal tubercles persist on another specimen (USNM 427918) to a diameter of $43 \mathrm{~mm}$. In addition, the ribs of some of these inner whorls are accentuated a little at the position where inner ventrolateral tubercles should appear, but distinct tubercles are not present.

The only small whorl (USNM 427939) observed in our collection from locality 21850 has a diameter of $8.3 \mathrm{~mm}$ and an umbilicus of $1.0 \mathrm{~mm}$ (ratio of 0.12 ). This inner whorl is somewhat distorted, but the whorl section is higher than it is wide and has a rounded umbilical shoulder, flattened flanks, and a broadly rounded venter. The only ornament visible is a row of prominent conical, rounded, inner ventrolateral tubercles. The venter is too poorly preserved to reveal siphonal tubercles. Larger whorls of the specimen that yielded the small whorl have weak siphonal clavi out to a diameter of $28.5 \mathrm{~mm}$, where they disappear; low nodate to somewhat clavate outer ventrolateral tubercles continue out to a diameter of about $42 \mathrm{~mm}$ before disappearing.

At diameters of 20 to $40 \mathrm{~mm}$, whorls from locality 21850 are moderately compressed and fairly involute and have umbilical ratios of 0.20 to 0.21 . The umbilicus is shallow and displays a rounded umbilical shoulder and sloping walls. Whorl sections have a breadth-to-height ratio of about 0.8 , the greatest breadth being low on the flank's intercostal section or at the umbilical bullae (where present) in costal section. Flanks are broadly rounded and convergent to the narrow venter, which is flattened on both the costal and the intercostal sections. Seven to nine low, blunt umbilical bullae are present per whorl. The bullae give rise to low, broad, slightly flexuous, prorsiradiate ribs that usually are paired. Secondary ribs arise at or below midflank to make a total of 11 or 12 ribs per half whorl. All ribs support clavate outer ventrolateral tubercles that border the flat venter. A low, broad swelling connects the ventrolateral clavi across the venter.

On specimens 40 to $60 \mathrm{~mm}$ in diameter from locality 21850 , the umbilical wall flattens, and the shoulder becomes indistinct. Umbilical bullae and ventrolateral tubercles weaken and disappear, but ribs that cross the venter become stronger. One specimen (USNM 427915) has a low, weakly undulated siphonal ridge that persists out to a diameter of about $54 \mathrm{~mm}$. Ribs increase in number to 12 to 15 per half whorl.

Body chambers begin at diameters ranging from 31 to $94 \mathrm{~mm}$ and occupy a little more than half a whorl (pl. 3). Maturity is indicated by marked excentricity of the umbilical seam (pl. 2, figs. 8, 11, 14), further flattening of the umbilical wall, disappearance of umbilical bullae, and broadening of the venter; specimens that have weakly ribbed phragmocones become nearly smooth except near the aperture, where strong foldlike ribs may appear. The more strongly ornamented specimens $70 \mathrm{~mm}$ in diameter or larger have 13 to 19 ribs per half whorl. Ribs are rectiradiate to prorsiradiate and are broadest and strongest where they cross the venter. Secondary ribs lengthen, and, when the umbilical bullae disappear, primaries and secondaries are poorly differentiated or undifferentiated (pl. 1, fig. 8; pl. 2, fig. 15). The aperture is normal.

Thirty-three specimens from locality 21850 are suitable for measurements of the diameter, whorl breadth, whorl height, umbilicus, and base of the body chamber (table 1).

The specimens from locality 21850 have a considerable size range at the base of the body chamber, but no distinct size groups suggestive of sexual dimorphism can be demonstrated. Diameters at the base of body chambers range from 31.0 to $94.1 \mathrm{~mm}$ (table 1). The smallest specimen (table 1, USNM 427908; pl. 2, figs. 6, 7) is probably a juvenile inasmuch as ventrolateral clavi are present on the preserved part of the body chamber, and the last sutures are not crowded. Another small specimen (table 1, USNM 427910), however, may be a true microconch; it has a basal body chamber diameter of just $32.2 \mathrm{~mm}$, and ornament on the body chamber consists only of ribs like those on larger specimens.

Much variation in ornament is also apparent in the specimens from locality 21850 . The more robust individuals tend to have coarsely ribbed body chambers (pl. 3), whereas the more slender forms have weakly ribbed to almost smooth body chambers (pl. 1, figs. 13-15). Some slender specimens have exceptionally smooth body chambers except for a few coarse, foldlike ribs near the aperture and weaker undulations farther back along the venter.

Sutures (text figs. $2 B-D$ ) are fairly simple. The external (E) and lateral (L) lobes are about the same size and somewhat squarish to rectangular. $\mathrm{L}$ and $\mathrm{E} / \mathrm{L}$ saddles are usually bifid, but $\mathrm{L}$ may assume a pseudotrifid appearance 
Table 1. Dimensions and ratios of Metoicoceras praecox Haas from U.S. Geological Survey Mesozoic locality $21850^{1}$ $[D$, diameter; $W b$, whorl breadth; $W h$, whorl height; $U$, umbilicus; --, no measurement]

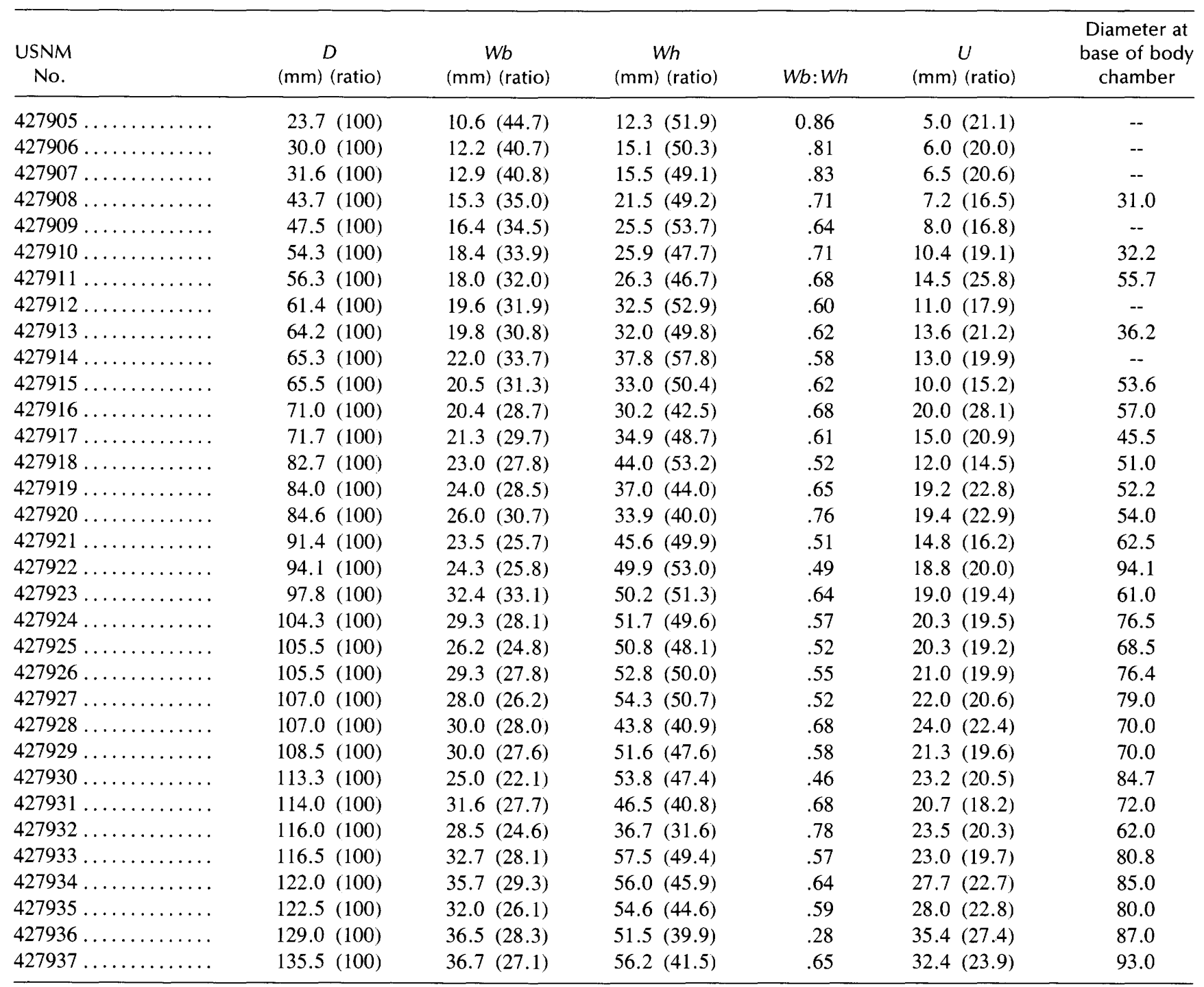

${ }^{1}$ From basal part of Cody Shale in the SE1/4 sec. 9, T. 53 N., R. 92 W., Big Horn County, Wyoming.

(text fig. 2D) (Haas, 1949, fig. 9). Umbilical lobes tend to be narrow, and the adjacent saddles are broad and little divided (text fig. 2) (Haas, 1949, figs. 5-9).

Discussion.-Metoicoceras praecox differs from other species of the genus in its lack of inner ventrolateral tubercles, except for a brief appearance on one of the innermost whorls. The species also differs from most other forms in its more evolute coiling and in its possession of siphonal tubercles on the early whorls. Metoicoceras latoventer Stephenson (1953, p. 209, pl. 53, figs. 1-9; pl. 54, figs. 9-11) has siphonal tubercles on the innermost whorls, but that species has more robust whorls displaying squarish sections (text fig. $3 \mathrm{H}$ ) and a simpler suture (text fig. $2 \mathrm{~A}$ ). Metoicoceras swallovi (Shumard, 1860, p. 591) has faint siphonal clavi on the innermost whorls, and the adults are as evolute as $M$. praecox, but $M$. swallovi has both inner and outer ventrolateral tubercles and retains the outer ones on the body chamber (Stephenson, 1953, pl. 52, figs. 2-5). The suture of $M$. swallovi is also more simplified (text fig. $2 E$ ) (Stephenson, 1953, pl. 52, figs. 2, 3). Slender forms of $M$. praecox that have nearly smooth body chambers except for coarse ribs near the aperture are like $M$. frontierense Cobban (1988, pl. 14); the latter differs mainly in that both inner and outer ventrolateral tubercles are present on most of the phragmocone.

\section{SEQUENCE OF METOICOCERAS IN THE WESTERN INTERIOR}

The oldest Metoicoceras in the Western Interior may be represented by some juvenile whorls (pl. 4, figs. 1-6) from the Belle Fourche Shale at USGS Mesozoic locality 

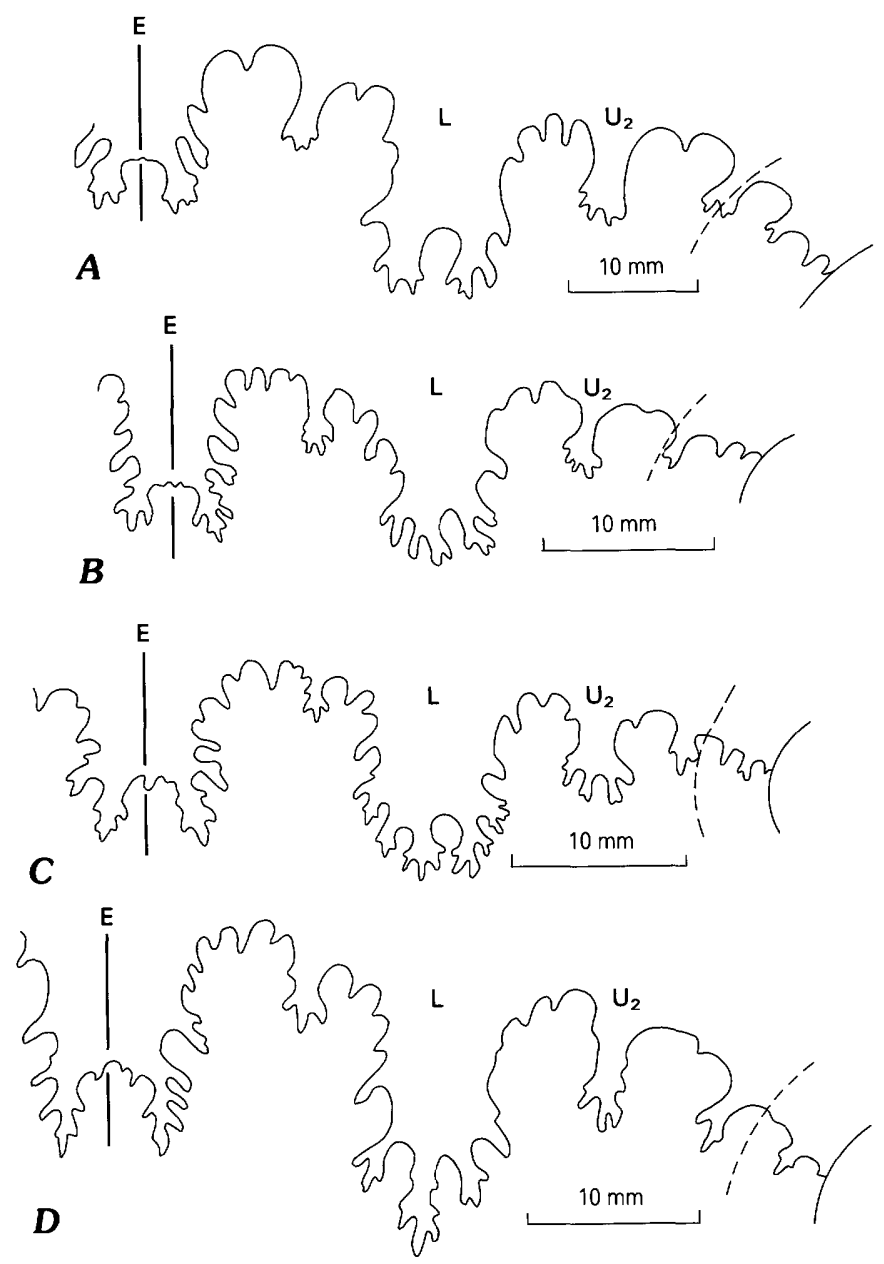

Figure 2. External sutures of Metoicoceras. A, M. latoventer Stephenson, hypotype USNM 427945 at a diameter of $116 \mathrm{~mm}$, from the Templeton Member of the Woodbine Formation at USGS Mesozoic locality 17163 about $4.5 \mathrm{~km}$ southeast of the center of Whitesboro, Grayson County, Texas. $B-D, M$. praecox Haas, from the basal part of the Cody Shale at USGS Mesozoic locality 21850 about $16 \mathrm{~km}$ northeast of Greybull, Big Horn County, Wyoming. B, Hypotype USNM 427944, fourth-from-last suture at a whorl height of $28 \mathrm{~mm}$; C, hypotype USNM 427929, fourth-from-last suture at a diameter of $60 \mathrm{~mm} ; D$, hypotype USNM 427927, fourth-from-last suture at a diameter of $70 \mathrm{~mm}$. E, M. swallovi (Shumard), hypotype USNM 427942 , sixth-from-last suture at a diameter of $51 \mathrm{~mm}$, from the Templeton Member of the Woodbine Formation at

D5947 on the western flank of the Black Hills uplift in the NW $1 / 4$ sec. 14, T. 47 N., R. 65 W., Weston County, Wyoming. This species, which we are referring to as $M$. sp. $\mathrm{A}$, is probably from low in the zone of Dunveganoceras pondi. Whorls are fairly stout, like those of similar-sized specimens of $M$. latoventer, but the ornament on the outer whorls as well as on the innermost ones is quite different and more like that of $M$. praecox. The smallest specimen (USNM 923751) has a diameter of $12.0 \mathrm{~mm}$, a breadth of

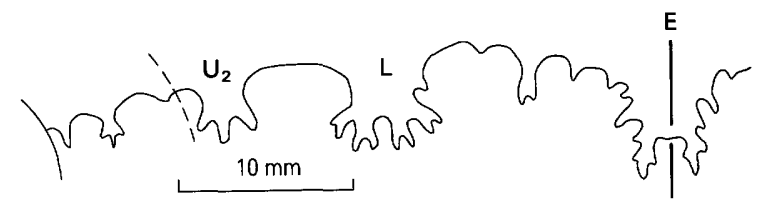

E

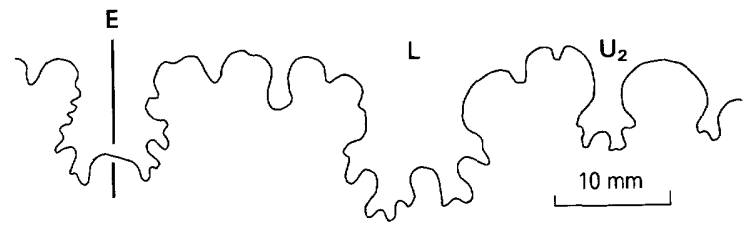

F

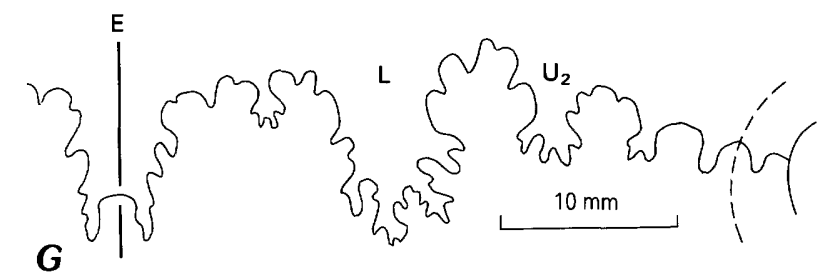

USGS Mesozoic locality 14546 in the bed of Red River about $13 \mathrm{~km}$ east of Arthur City, Lamar County, Texas. F, $M$. bergquisti Cobban, hypotype USNM 427946, most of external suture at a whorl height of about $53 \mathrm{~mm}$, from the Coleraine Formation at USGS Mesozoic locality 13060 at the Arcturus mine, Marble, Itasca County, Minnesota. G, M. mosbyense Cobban, hypotype USNM 220382, fifthfrom-last suture at a diameter of $61 \mathrm{~mm}$, from the Mosby Sandstone Member of the Belle Fourche Shale at USGS Mesozoic locality 21486 about $1.6 \mathrm{~km}$ southwest of Yellow Water Reservoir in the NE $1 / 4$ sec. 14, T. 13 N., R. 25 E., Petroleum County, Montana. $H, M$. geslinianum (d'Orbigny), hypotype USNM 427950, seventh-from- last suture at a diameter of $83.5 \mathrm{~mm}$, from the Britton Formation $2.5 \mathrm{~km}$ southeast of Britton, Ellis County, Texas.

$7.7 \mathrm{~mm}$ (ratio of 0.64 ), a height of $6.4 \mathrm{~mm}(0.53)$, a whorl breadth to whorl height ratio of 1.2 , and an umbilicus of $10.3 \mathrm{~mm}(0.86)$. At the smallest end of the outer whorl, ornament consists only of low rectiradiate ribs that end in conspicuous nodate inner ventrolateral tubercles that are spaced at eight per whorl. By the end of the first quarter of a whorl, at a diameter of about $6.7 \mathrm{~mm}$, weak nodate outer ventrolateral tubercles appear, as do weak secondary ribs that support faint inner and outer ventrolateral tubercles. 


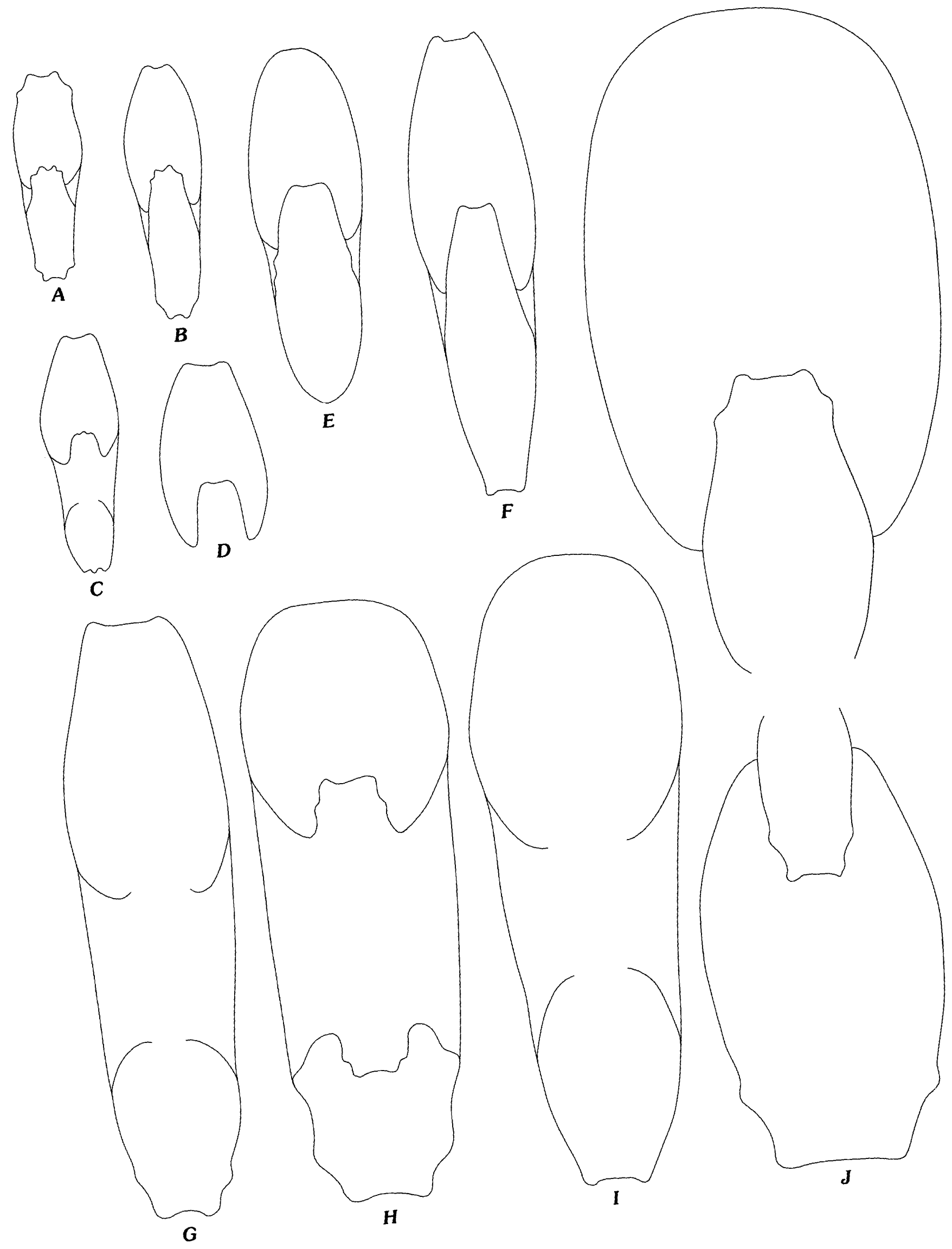


Low, rounded siphonal tubercles arise at the end of the first half of the outer whorl at a diameter of about $7.3 \mathrm{~mm}$. As the whorl enlarges, the ribs become stronger, and the primaries arise from umbilical bullae. At the position of the inner ventrolateral tubercle, each rib bends forward and terminates in the outer ventrolateral tubercle. Primary and secondary ribs alternate, and each bears inner and outer ventrolateral tubercles. The outer ventrolateral tubercles strengthen, but the inner ones weaken, and, at the larger end of the whorl, the inner ones disappear. Outer ventrolateral tubercles are strong and nodate at the end of the whorl. Each of these tubercles is matched by a weak clavate siphonal tubercle. Another inner whorl (USNM 423752) from locality D5947 verifies this sequence of ornament. The earliest whorls have only weak primary ribs and conical inner ventrolateral tubercles that weaken and disappear by a diameter of $9.8 \mathrm{~mm}$. As these tubercles weaken, outer ventrolateral tubercles arise, and, by a diameter of $10 \mathrm{~mm}$, the outer ones become conspicuous and somewhat clavate.

Small specimens (pl. 5, figs. 4-11) from another locality on the western flank of the Black Hills show a similar early development of ornament. This collection

Figure 3. Costal whorl sections (natural size) of various species of Metoicoceras. A, M. geslinianum (d'Orbigny), hypotype USNM 425303 at a diameter of $39 \mathrm{~mm}$, from the Colorado Formation at USGS Mesozoic locality D11529 in the $\mathrm{NW} 1 /{ }_{2} \mathrm{NE}^{1} / 2$ sec. $11, \mathrm{~T}$. $18 \mathrm{~S}$., R. 18 W., Grant County, New Mexico. B, M. mosbyense Cobban, hypotype USNM 427947 at a diameter of 48 $\mathrm{mm}$, from the Mosby Sandstone Member of the Belle Fourche Shale at USGS Mesozoic locality 21485 in the SW $y_{2}$ sec. 1, T. 13 N., R. 25 E., Petroleum County, Montana (pl. 5, figs. 1-3) C, M. praecox Haas, hypotype USNM 427908 at a diameter of $44.5 \mathrm{~mm}$, from the basal part of the Cody Shale at USGS Mesozoic locality 21850 about $16 \mathrm{~km}$ northeast of Greybull, Big Horn County, Wyoming (pl. 2, figs. 6, 7). D, M. bergquisti Cobban, holotype UMIP 9004, at a whorl height of $34.5 \mathrm{~mm}$, from the Coleraine Formation at the Arcturus mine, Marble, Itasca County, Minnesota. E, M. praecox Haas, hypotype USNM 427914 at a diameter of $66 \mathrm{~mm}$, from the same locality as $C$ (pl. 2, figs. 10-12). F, M. mosbyense Cobban, hypotype USNM 220382 at a diameter of $87 \mathrm{~mm}$, from the same locality as $B$ (pl. 5, figs. 15-17). G, M. swallovi (Shumard), hypotype USNM 105991 at a diameter of $113 \mathrm{~mm}$, from the Templeton Member of the Woodbine Formation at USGS Mesozoic locality 13797 about $13 \mathrm{~km}$ east of Arthur City, Lamar County, Texas. H, M. latoventer Stephenson, hypotype USNM 427945 at a whorl height of $38 \mathrm{~mm}$, from the Templeton Member of the Woodbine Formation at USGS Mesozoic locality 17183 about $4.5 \mathrm{~km}$ southeast of the center of Whitesboro, Grayson County, Texas (pl. 5, figs. 18, 19). I, M. mosbyense Cobban, hypotype USNM 427949 at a diameter of $118 \mathrm{~mm}$, from the same locality as $B$ and $F$. J, M. geslinianum (d'Orbigny), hypotype USNM 411503 at a diameter of $216 \mathrm{~mm}$, from the Britton Formation $4 \mathrm{~km}$ south of Britton, Ellis County, Texas. consists of four well-preserved specimens from a limestone concretion from the lower part of the Greenhorn Formation at USGS Mesozoic locality D4462 in the NE1/4 sec. 24, T. 47 N., R. 65 W., Weston County, Wyoming. These specimens, herein referred to as $M$. aff. praecox, have inner ventrolateral tubercles that persist to large diameters. These tubercles are absent on even the smallest topotypes of $M$. praecox from locality 21850 , and the ribs are narrower and sharper. The smallest specimen (USNM 423755) from locality D4462 has a diameter of $9.2 \mathrm{~mm}$ and an umbilicus of only $0.8 \mathrm{~mm}$ (ratio to diameter of 0.09 ). The outer whorl has a somewhat squarish section that is a little broader than it is high and exhibits flattened flanks and a broadly rounded to slightly flattened venter. Ornament at the small end of the outer whorl consists only of nodate inner ventrolateral tubercles. Nodate outer ventrolateral tubercles arise at about the end of the first half of the whorl at a diameter of about $6 \mathrm{~mm}$. Prorsiradiate ribs arise slightly farther out, and the first umbilical bulla appears at the end of the whorl. Faint siphonal clavi are present also by the end of the whorl. On the complete outer whorl, 12 inner ventrolateral tubercles are present; they are nodate and strong on most of the whorl, but, near the larger end, they weaken and become bullate. Another small specimen (pl. 5, figs. 4-6), $10 \mathrm{~mm}$ in diameter, shows this same development of ornament except that the inner ventrolateral tubercles are still strong and nodate at the larger end. On a third specimen ( $\mathrm{pl} .5$, figs. 9-11), the inner ventrolateral tubercles disappear at the base of the body chamber at a diameter of about $12.5 \mathrm{~mm}$. Ornament on this small body chamber consists of umbilical bullae; narrow, prorsiradiate primary and secondary ribs that curve forward and rise into conspicuous outer ventrolateral clavi; and weak siphonal clavi located on broad, transverse swellings. A fourth small specimen (pl. 5, figs. 7,8 ) is part of a body chamber ornamented like the third specimen. Whether these specimens represent a very small species of Metoicoceras or whether they represent juvenile $M$. praecox cannot be determined from the small collection at hand.

Typical $M$. praecox, such as those from locality 28150 , occur with Dunveganoceras pondi and Calycoceras canitaurinum (Haas). All three species occur in the basal bed of the Greenhorn Formation in the Black Hills area of northeastern Wyoming, southeastern Montana, and western South Dakota.

In the Frontier Formation in north-central Wyoming, a zone of ammonites of early late Cenomanian age can be recognized between the zones of $D$. pondi and Metoicoceras mosbyense (Cobban, 1988, p. 14, 15). Ammonites in this zone include Calycoceras aff. C. canitaurinum (Haas) and the new species $D$. problematicum, $M$. frontierense ( $\mathrm{pl}$. 6, figs. 11-15), and $M$. aff. frontierense (pl. 6, figs. 1618 ). The latter species was foreshadowed by fairly smooth variants of $M$. praecox that have rejuvenated ribbing at the aperture. As we pointed out earlier, $M$. frontierense differs 
from its ancestor in that inner ventrolateral tubercles persist well out on most or all of the phragmocone whorls. In addition, the venter of $M$. frontierense tends to be smooth on adult body chambers, whereas it is undulose in $M$. praecox. This smooth-ventered body chamber stage seems to ally $M$. frontierense to $M$. bergquisti Cobban (1983, p. 14 ; pl. 8 , figs. $1-4$; pl. 12 , figs. $1-5$; pl. 13 ; pl. 14 , figs. 1-5, 10-15), a species described from Minnesota. Metoicoceras bergquisti is a stouter species that attains a much larger size and has a flatter but smooth adult venter. This species is probably younger than $M$. frontierense, inasmuch as an associated ammonite, D. hagei Warren and Stelck (1955, p. 69, pl. 5, fig. 1), is more closely related to D. albertense (Warren, 1930, p. 21; pl. 1, figs. 1, 2) and $D$. conditum Haas (1951, p. 5, figs. 2-9) than it is to D. pondi. Both $D$. albertense and $D$. conditum are found in the zone of $M$. mosbyense. Metoicoceras bergquisti has both inner and outer ventrolateral tubercles on most or all of the phragmocone, although the inner tubercles weaken and disappear on early whorls of the more slender and smoother variants. The earliest whorls of this species have not been seen. A body chamber of the species was recently found in the Woodbridge Member of the Raritan Formation in the clay pit of the Fisher Brick Company at Sayreville, Middlesex County, New Jersey (USGS Mesozoic locality 29584), the first occurrence of the genus on the Atlantic coast of the United States.

Metoicoceras mosbyense, which characterizes the next zone above $M$. frontierense, is abundant and widely distributed from north-central Montana to southwestern New Mexico. The species differs from all older forms in that ribs become flattened on the outer part of the flank near the end of the phragmocone and on the adjacent part of the body chamber, where they cross the venter transversely as broad, flat-topped swellings. Dimorphism is now recognized in this species. The holotype (Cobban, 1953, p. 48, pl. 7) is an adult microconch, whereas the holotype of $M$. muelleri Cobban (1953, p. 49, pl. 8, fig. 7; pl. 9) is an adult macroconch. Adult microconchs, which are as small as 125 $\mathrm{mm}$ in diameter, are moderately stout and rather strongly ornamented. Inner ventrolateral tubercles may persist to a diameter of $25 \mathrm{~mm}$, whereas the outer ventrolateral tubercles are present to the end of the phragmocone. Umbilical bullae may be present on all the phragmocone whorls. Adult macroconchs may attain diameters of 260 to $285 \mathrm{~mm}$, or they may be as small as $180 \mathrm{~mm}$ (pl. 4, figs. 7, 8). Macroconchs are more slender and more weakly ornamented than microconchs, and umbilical bullae may be absent (pl. 5, fig. 17). Adult body chambers usually have a pronounced change in ribbing from broad, flat ribs on the older part to more closely spaced, narrow ones on the younger part (pl. 4, figs. 7, 8). Inner ventrolateral tubercles disappear at some diameter between 7 and $11 \mathrm{~mm}$.

The innermost whorls of both the macroconch and the microconch have been described in detail by Cobban (1953, p. 48-52, pl. 6, figs. 1-6). Ornament of these innermost whorls is much like that of the innermost whorls of older species in that strong, nodate inner ventrolateral tubercles arise before any of the other ornament. A change occurs, however, in the early development of the outer ventrolateral tubercles. These tubercles occur in pairs along the ventrolateral shoulder, separated by smooth spaces, and each of the pairs is set forward a little from the larger inner ventrolateral tubercle, like the one shown by Hyatt (1903, pl. 11, fig. 14).

Metoicoceras geslinianum (d'Orbigny, 1850, p. 146) (pl. 6, figs. 1-10), the youngest species of the genus in the Western Interior, occurs in the zone of Sciponoceras gracile near the top of the Cenomanian. Metoicoceras geslinianum descended from $M$. mosbyense, from which it differs mainly in that inner ventrolateral tubercles persist out onto the adult body chamber. Ribs flatten on the outer part of the flank near the end of the phragmocone and the adjacent part of the body chamber, just as they do on $M$. mosbyense. The earliest whorls, however, show a change not observed in the $M$. mosbyense whorls. Outer ventrolateral tubercles occur in pairs, as they do in $M$. mosbyense, but a constriction that arises on the ventrolateral shoulder and arches across the venter separates each tubercle of a pair. These pairs and constrictions disappear at a diameter of about 8 or $9 \mathrm{~mm}$, and, at larger diameters, ventrolateral tubercles are regularly spaced.

Dimorphism is conspicuous in $M$. geslinianum and closely parallels that of $M$. mosbyense. Microconchs are fairly evolute, robust, and coarsely ornamented. Adults range in diameter from 135 to $210 \mathrm{~mm}$. Macroconchs are more involute and compressed and have weaker ornament. Adults attain diameters ranging from 195 to $245 \mathrm{~mm}$. The dimorphism has been well described and illustrated by Wright and Kennedy (1981) and Kennedy (1988).

Metoicoceras geslinianum is abundant in the basal part of the Bridge Creek Member of the Greenhorn Limestone in the central Great Plains and in the equivalent rocks farther west and southwest in southern Utah, northeastern Arizona, southwestern Colorado, and much of New Mexico. From this large endemic center, the species migrated southward into Trans-Pecos Texas and Chihuahua, Mexico, and eastward across Texas. Ecologic conditions at this time must have been perfect for widespread migration, because the species has been found in Brazil, Africa, western Europe, Israel, Iran, and the U.S.S.R.

Following this great migration, Metoicoceras seems to have disappeared. The genus is believed to have given rise to Spathites Kummel and Decker, 1954, of latest Cenomanian through middle Turonian age (Kennedy and others, 1980).

\section{ORIGIN OF METOICOCERAS}

Wright (1956) suggested that Utaturiceras Wright, 1956 was the direct ancestor of Metoicoceras. The type 
species of Utaturiceras, Ammonites vicinalis Stoliczka (1864, p. 84, pl. 44, figs. $1,4,5,7,8$, non figs. $2,3,6$ ), has been well described by Matsumoto and Sarkar (1966), who designated as lectotype the adult specimen figured by Stoliczka (1864, pl. 44, fig. 8). This specimen is a compressed, fairly involute form that has high whorls and a narrow umbilical shoulder, slightly inflated flanks, and a narrow, flattened venter bordered by ventrolateral clavi. Ribs are numerous, prorsiradiate, and slightly flexuous on the body chamber and mostly of equal lengths, whereas the ribs are primary and secondary on the inner whorls. Inner and outer ventrolateral tubercles are present on the whorls out to the body chamber, where the inner ones weaken to slight swellings on the ribs. On the innermost whorls of a paratype (Matsumoto and Sarkar, 1966, pl. 33, fig. 1a-c), inner ventrolateral tubercles form first, and outer ones form later. The lectotype shows some resemblance to the splendid adult specimen of $M$. swallovi illustrated by Stephenson (1953, pl. 52, figs. 2-5), but their sutures are totally different. Metoicoceras swallovi has a simple pseudoceratitic suture marked by short lobes, whereas $U$. vicinale has a complex suture characterized by long lobes. Utaturiceras is a lower Cenomanian member of the Mantelliceratinae and is closely allied to Mantelliceres and Graysonites. Resemblance to Metoicoceras is mere homeomorphy.

C.W. Wright and W.J. Kennedy (Juignet and others, 1973, p. 25) proposed the upper Cenomanian genus Thomelites and suggested that it might be ancestral to Metoicoceras. Thomelites (type species Jeanrogericeras sornayi Thomel, 1966, p. 431, pl. 11, figs. 1-3) has rather massive umbilical tubercles from which arise one to three ribs, each bearing inner and outer clavate ventrolateral tubercles that are matched on the venter by conspicuous siphonal clavi. These siphonal clavi persist out to the outer whorl. In their treatment on Spathites, Kennedy and others (1980, p. 822) continued to show Thomelites as ancestral to Metoicoceras, but, a little later, Kennedy and others (1981, p. 54) pointed out differences between Thomelites and Metoicoceras and noted that these genera "coexisted in time but not in space." In fact, Metoicoceras is known to appear in the middle Cenomanian, before Thomelites, which is known only from the upper Cenomanian.

All three Gulf Coast species of Metoicoceras came from the middle Cenomanian Templeton Member of the Woodbine Formation in northern Texas. All are rare: $M$. swallovi, the type species of the genus, is represented in the USGS collections by seven specimens in addition to the five figured by Stephenson (1953); M. latoventer is represented by three specimens in addition to the four figured by Stephenson; and $M$. crassicostae is known from the holotype and one other specimen. No other ammonites are known to have been associated with $M$. swallovi at its type locality, and the holotype has been lost. This species has been found at several other localities in northern Texas, but the only other ammonite with it is Metengonoceras dumbli
(Cragin), a species that seems to be of late middle Cenomanian age (Cobban, 1987b), suggestive of an age older than that of the Western Interior $M$. praecox.

Early whorls of $M$. swallovi were examined from a phragmocone that was collected at the type locality of the species at USGS Mesozoic locality 14546 from the bed of Red River near old Slate Shoals $12.9 \mathrm{~km}$ east of Arthur City, Lamar County, Texas (Stephenson, 1953, p. 42, loc. 201). The smallest whorl examined (USNM 427941) has a diameter of $10 \mathrm{~mm}$, but the umbilicus is not preserved. Flanks and venter are well rounded and smooth at the small end, whereas flanks are flattened and the venter is broadly rounded at the larger end. Faint rectiradiate primary ribs and nodate inner and outer ventrolateral tubercles arise together on the older part of the whorl at a diameter of about 5.5 $\mathrm{mm}$. This ornament is well defined on the younger half of the whorl, where every other inner ventrolateral tubercle lies on a primary rib. A rib bends forward from each inner tubercle and terminates in an equal-sized outer ventrolateral tubercle. All inner tubercles are nodate; the outer ones are nodate at first but become clavate by the end of the whorl. Faint siphonal tubercles also arise on the last half of the whorl; each matches an outer ventrolateral tubercle. Inner ventrolateral tubercles number 9 or 10 on the last half of this whorl. The ornament contrasts greatly with the ornament on similar-sized whorls of $M$. praecox, where these tubercles are absent.

Metoicoceras latoventer has not been found with $M$. swallovi, although both species are said to occur in the Templeton Member of the Woodbine Formation. Ammonites found with $M$. latoventer are Metengonoceras dumbli (Cragin) and "Acanthoceras" cuspidum Stephenson (1953). The latter species has been found in both the Plesiacanthoceras wyomingense and Dunveganoceras pondi zones in the Black Hills area of the Western Interior. The first zone has been considered as latest middle Cenomanian and the other as earliest late Cenomanian (Cobban, 1984). The presence of Metengonoceras dumbli favors a late middle Cenomanian age near that of Metoicoceras swallovi.

The small inner whorls of $M$. latoventer are like those of $M$. swallovi. A paratype (USNM 105999) figured by Stephenson (1953, pl. 53, figs. 5-7) has equal-sized umbilical and inner and outer ventrolateral tubercles on a whorl about $11 \mathrm{~mm}$ in diameter. Inner ventrolateral tubercles are nodate, and every other one is connected to a nodate umbilical tubercle by a low, prorsiradiate primary rib. Clavate outer ventrolateral tubercles are set forward a little from the inner ones, and each is matched by a weaker siphonal clavus. The last half whorl has four umbilical tubercles and seven ventrolateral tubercles. Sutures of $M$. latoventer (text fig. 2A) are like those of $M$. swallovi (text fig. $2 E$ ) in that the saddles are little divided or undivided.

The holotype of $M$. crassicostae is a complete adult from USGS Mesozoic locality 20314 about $4.3 \mathrm{~km}$ north of Bells, Grayson County, Texas. The specimen has more 
rounded whorls and fewer ribs than $M$. latoventer does, and the umbilical tubercles are stronger and conical. Sutures, however, are similar. Ammonites from the type locality of M. crassicostae are Metengonoceras dumbli and the species described by Stephenson (1953) as Mammites? bellsanus. The latter species is better assigned to Plesiacanthoceras Haas, 1964, as Cobban (1987a, p. 18) has already suggested. The presence of Plesiacanthoceras and Metengonoceras dumbli again suggests a middle Cenomanian age for the Templeton Member of the Woodbine Formation and a correlation with the $P$. wyomingense zone of the Western Interior.

Although Metoicoceras swallovi, M. crassicostae, and $M$. latoventer share several common features and are regarded as a closely related group, we cannot put them in stratigraphic sequence. Their origin probably lies in some contemporary member of the Acanthoceratinae, and Stephenson included in his type series of $P$. bellsanum a paratype specimen (USNM 105986) that is actually a $M$. crassicostae. The ornament of this specimen is close to that of the holotype of $P$. bellsanum (Stephenson, 1953, pl. 51, figs. 8-11), but it is more compressed and has much simpler sutures. This evidence suggests that the origin of the early Gulf Coast Metoicoceras lay in Plesiacanthoceras, which evolved sutural simplification and profound modification of adult ornament.

The oldest Metoicoceras from the Western Interior come from the lower part of the upper Cenomanian and are thus younger than the Gulf Coast species. Metoicoceras sp. A has several features in common with $M$. latoventer on its inner whorls but shows early loss of inner ventrolateral tubercles combined with a stout whorl section. Metoicoceras aff. praecox has a more compressed section than $M$. sp. A does but has distinct inner ventrolateral tubercles, which separate it from the topotype series of $M$. praecox, where these tubercles are incipient only in some specimens. There is thus a series of early stages that might be linked as $M$. latoventer giving rise to $M$. sp. A giving rise to $M$. aff. praecox and then to $M$. praecox itself, although we do not have adults of the middle two to be certain. Furthermore, the suture lines of $M$. crassicostae are much simpler than those of $M$. praecox. $M$. praecox stands apart from all other species in its lack of inner ventrolateral tubercles and may be an offshoot of the main Metoicoceras lineage that gave rise to $M$. bergquisti, $M$. frontierense, $M$. mosbyense, and $M$. geslinianum, all of which may have arisen from the poorly known species of the Dunveganoceras pondi zone (M. aff. praecox, $M$. sp. A), in which inner ventrolateral tubercles are present in juveniles and adults, and in the progressive increase in the degree of incision of the lobes and saddles (text fig. 2).

\section{REFERENCES CITED}

Cobban, W.A., 1953, Cenomanian ammonite fauna from the Mosby sandstone of central Montana: U.S. Geological Survey Professional Paper 243-D, p. D45-D55, pls. 6-12.

1977, Characteristic marine molluscan fossils from the Dakota Sandstone and intertongued Mancos Shale, westcentral New Mexico: U.S. Geological Survey Professional Paper 1009, 30 p., 21 pls.

1983, Molluscan fossil record from the northeastern part of the Upper Cretaceous seaway, Western Interior, in Cobban, W.A., and Merewether, E.A., Stratigraphy and paleontology of mid-Cretaceous rocks in Minnesota and contiguous areas: U.S. Geological Survey Professional Paper 1253-A, p. A1-A23, pls. 1-15.

1984, Mid-Cretaceous ammonite zones, Western Interior, United States: Bulletin of the Geological Society of Denmark, v. 33, p. 71-89.

1987a, Some middle Cenomanian (Upper Cretaceous) acanthoceratid ammonites from the Western Interior of the United States: U.S. Geological Survey Professional Paper 1445, 28 p., 13 pls.

1987b, The Upper Cretaceous (Cenomanian) ammonites Metengonoceras dumbli (Cragin) and M. acutum Hyatt: U.S. Geological Survey Bulletin 1690-C, p. C1-C7, 3 pls.

1988, Some acanthoceratid ammonites from upper Cenomanian (Upper Cretaceous) rocks of Wyoming: U.S. Geological Survey Professional Paper 1353, 17 p., 15 pls.

Cobban, W.A., and Reeside, J.B., Jr., 1952, Correlation of the Cretaceous formations of the Western Interior of the United States: Geological Society of America Bulletin, v. 63, no. 10, p. 1011-1043.

Grossouvre, A., de, 1894, Les ammonites de la craie supérieure, pt. 2, Paléontologie, in Recherches sur la craie supérieure: Carte Géologique Détaillée de la France Mémoires, 264 p., 39 pls. [1893 imprint].

Haas, O., 1949, Acanthoceratid Ammonoidea from near Greybull, Wyoming: American Museum of Natural History Bulletin, v. 93, art. 1, 39 p., 15 pls.

1951, Supplementary notes on the ammonoid genus Dunveganoceras: American Museum Novitates 1490, 21 p.

1964, Plesiacanthoceras, new name for Paracanthoceras Haas, 1963, non Furon, 1935: Journal of Paleontology, v. 38, no. 3, p. 610 .

Hyatt, A., 1889, Genesis of the Arietidae: Smithsonian Contributions to Knowledge, v. 26, no. 637,238 p., 14 pls. (also published as Memoir of the Museum of Comparative Zoology, v. 16, no. 3, 238 p., 14 pls.).

1903, Pseudoceratites of the Cretaceous: U.S. Geological Survey Monograph 44, 351 p., 47 pls.

Ilyin, V.D., 1970, Verkhnesenomanskiye ammonity yugovostoka Sredney Azii [Upper Cenomanian ammonites of southeastern Central Asia], in Stratigrafiya i paleontologiya mezozoyskikh otlozheniy Sredney Azii: Vsesoyuznyy NauchnoIssledovatel'skiy Geologorazvedochnyi Neftianoi Institut, Trudy, no. 69, p. 10-23, 9 pls. 
Juignet, P., Kennedy, W.J., and Wright, C.W., 1973, La limite Cenomanien-Turonien dans la région du Mans (Sarthe); Stratigraphie et paléontologie: Annales de Paléontologie, v. 59, pt. 2, p. 209-242, 3 pls.

Kennedy, W.J., 1988, Late Cenomanian and Turonian ammonite faunas from north-east and central Texas: Palaeontological Association of London Special Papers in Palaeontology 39 , 131 p., 24 pls.

Kennedy, W.J., Juignet, P., and Hancock, J.M., 1981, Upper Cenomanian ammonites from Anjou and the Vendée, western France: Palaeontology, v. 24, pt. 1, p. 25-84, pls. 3-17.

Kennedy, W.J., Wright, C.W., and Hancock, J.M., 1980, Origin, evolution and systematics of the Cretaceous ammonoid Spathites: Palaeontology, v. 23, pt. 4, p. 821-837, pls. 104-106.

Kullmann, J., and Wiedmann, J., 1970, Significance of sutures in phylogeny of Ammonoidea: University of Kansas, Paleontological Contributions Paper 47, $32 \mathrm{p}$.

Kummel, B., and Decker, J.M., 1954, Lower Turonian ammonites from Texas and Mexico: Journal of Paleontology, v. 28, no. 3 , p. 310-319, pls. 30-33.

Matsumoto, T., and Sarkar, S.S., 1966, Utaturiceras vicinale (Stoliczka) from southern India, in Matsumoto, T., Sastry, M.V.A., and Sarkar, S.S., Notes on some Cretaceous ammonites from southern India: Memoirs of the Faculty of Science, Kyushu University, ser. D, Geology, v. 17, no. 3, p. 297-309, pls. 32, 33 .

Orbigny, A., d', 1850-52, Prodrome de paléontologie stratigraphique universelle des animaux mollusques et rayonnés: Paris, G. Masson, v. 2, 428 p.

Shimer, H.W., and Shrock, R.R., 1944, Index fossils of North America: New York, John Wiley, 837 p., 303 pls.
Shumard, B.F., 1860, Descriptions of new Cretaceous fossils from Texas: Transactions of the Academy of Sciences of St. Louis, v. 1, p. 590-610.

Stephenson, L.W., 1953, Larger invertebrate fossils of the Woodbine formation (Cenomanian) of Texas: U.S. Geological Survey Professional Paper 242, 211 p., 58 pls. [1952 imprint].

Stoliczka, F., 1864-66, The fossil Cephalopoda of the Cretaceous rocks of southern India (Ammonitidae): India Geological Survey Memoirs, Palaeontologia Indica, p. 41-216, pls. 26-94.

Thomel, G., 1966, Ammonoidea, in Porthault, B., Thomel, G., and de Villoutreys, O., Etude biostratigraphique du Cénomanien du bassin supérieur de l'Estéron (AlpesMaritimes) - Le problème de la limite Cénomanien-Turonien dans le Sud-Est de la France: Bulletin de la Société Géologique de France, 7th ser., v. 8, p. 427-432, pls. 8-11.

Warren, P.S., 1930, Three new ammonites from the Cretaceous of Alberta: Transactions of the Royal Society of Canada, 3d ser., v. 24 , sec. 4 , p. $21-26,4$ pls.

Warren, P.S., and Stelck, C.R., 1955, New Cenomanian ammonites from Alberta: Research Council of Alberta Report 70, p. $63-75$, pls. $4-9$.

Wedekind, R., 1916, Über Lobus, Suturallobus und Inzision: Zentralblatt für Mineralogie, Geologie, und Paläontologie, B, for 1916 , p. 185-195.

Wright, C.W., 1956, Notes on Cretaceous ammonites, pt. III, Utaturiceras gen. nov. and the Metoicoceratinae: Annals and Magazine of Natural History, ser. 12, v. 9, p. 391-393.

Wright, C.W., and Kennedy, W.J., 1981, The Ammonoidea of the Plenus Marls and the Middle Chalk: Palaeontographical Society [London] Monograph, 148 p., 32 pls.

Zittel, K.A., von, 1884, Handbuch der Palaeontologie, 1, Cephalopoda: Munich and Leipzig, Oldenbourg, Abt. 2, Lief. 3, p. 329-522. 



\section{PLATES 1-6}

Contact photographs of the plates in this report are available, at cost, from the U.S. Geological Survey Photographic Library, Federal Center, Denver, CO 80225. 


\section{PLATE 1}

\section{Metoicoceras praecox Haas (p. B2)}

[All figures natural size. Arrows point to base of body chambers]

Figures 1-15. From the basal part of the Cody Shale at U.S. Geological Survey Mesozoic locality 21850 in the SE1/4 sec. 9, T. 53 N., R. 92 W., Big Horn County, Wyoming.

1, 2. Hypotype USNM 427938.

3-5. Hypotype USNM 427906.

6, 7. Hypotype USNM 427905.

8, 9. Hypotype USNM 427916.

10-12. Hypotype USNM 427920.

13-15. Hypotype USNM 427928. 

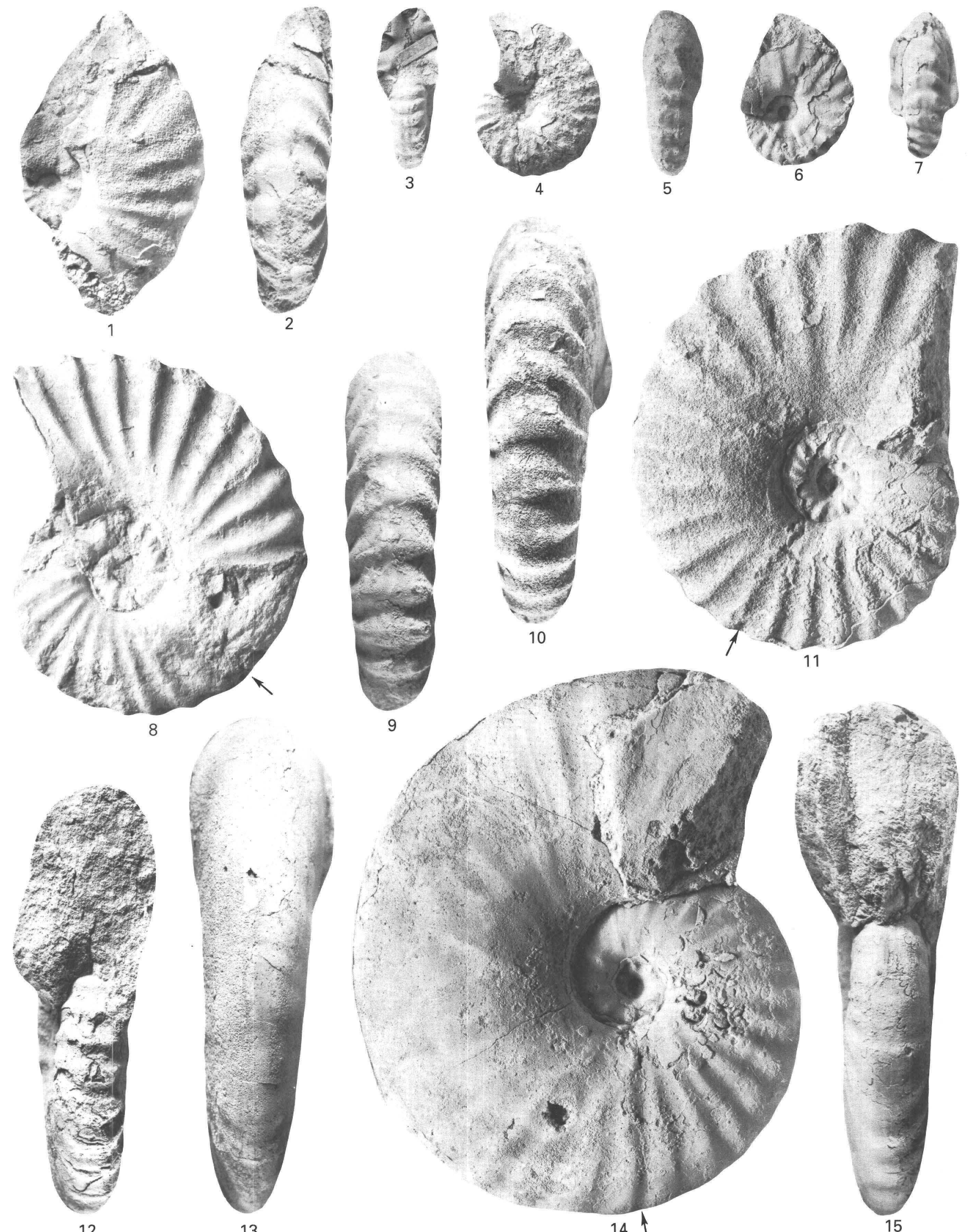

12

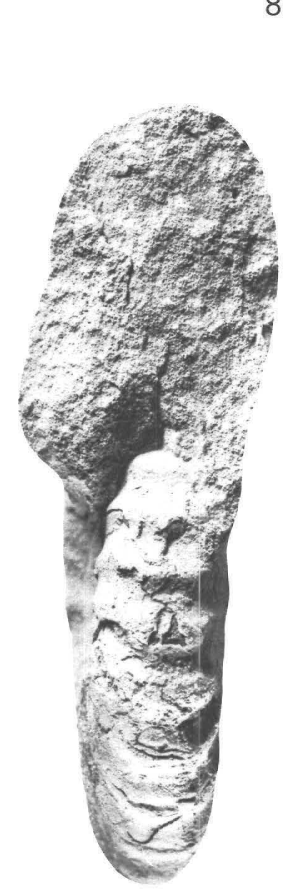

.

13

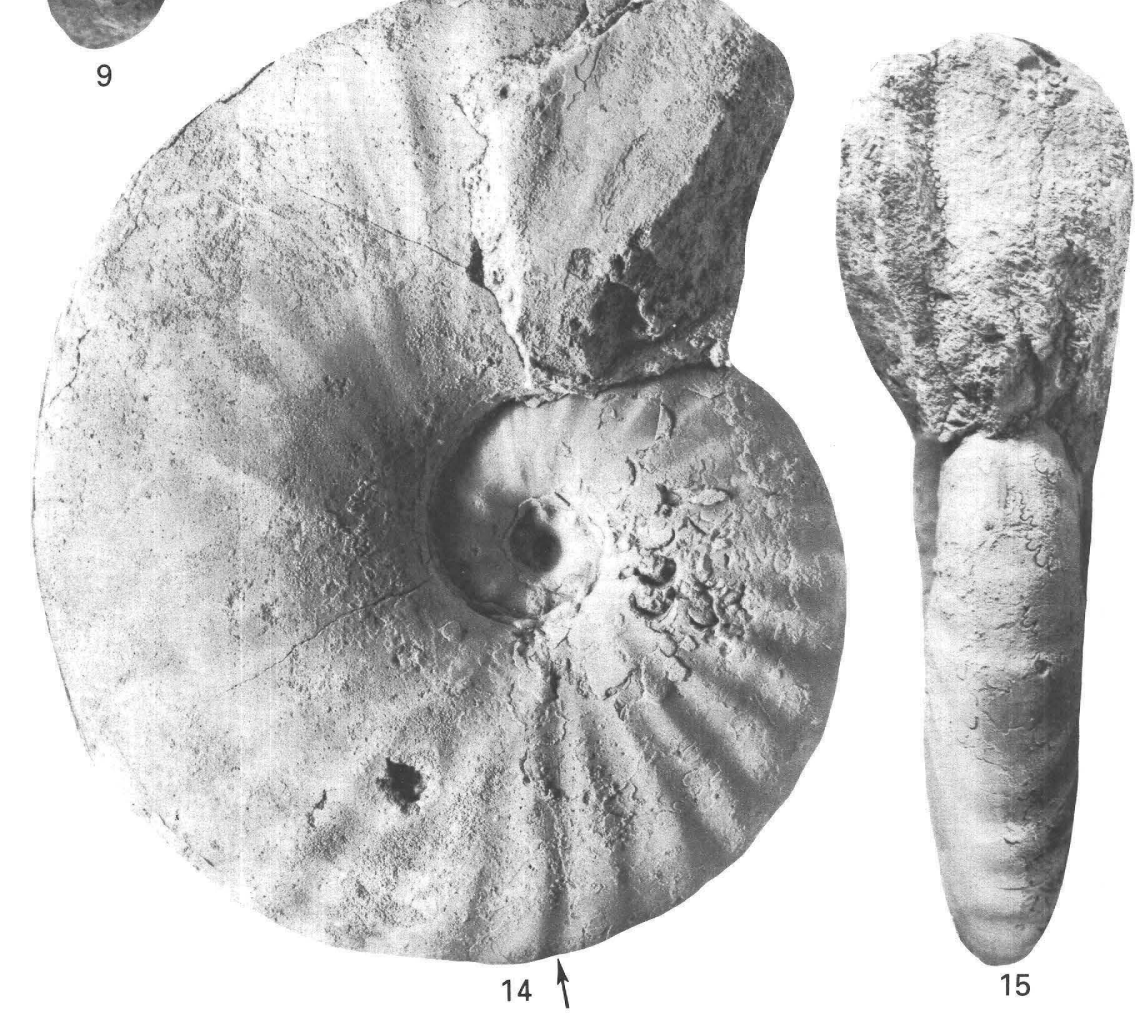

METOICOCERAS PRAECOX 
PLATE 2

Metoicoceras praecox Haas (p. B2)

[All figures natural size. Arrow points to base of body chamber]

Figures 1-16. From the basal part of the Cody Shale at U.S. Geological Survey Mesozoic locality 21850 in the SE1/4 sec. 9, T. 53 N., R. 92 W., Big Horn County, Wyoming.

1-3. Hypotype USNM 427909.

4, 5. Hypotype USNM 427907.

6, 7. Hypotype USNM 427908.

8, 9. Hypotype USNM 427912.

10-12. Hypotype USNM 427914.

13. Hypotype USNM 427929.

14-16. Hypotype USNM 427940. 
BULLETIN 1934-B PLATE 2

U. S. GEOLOGICAL SURVEY

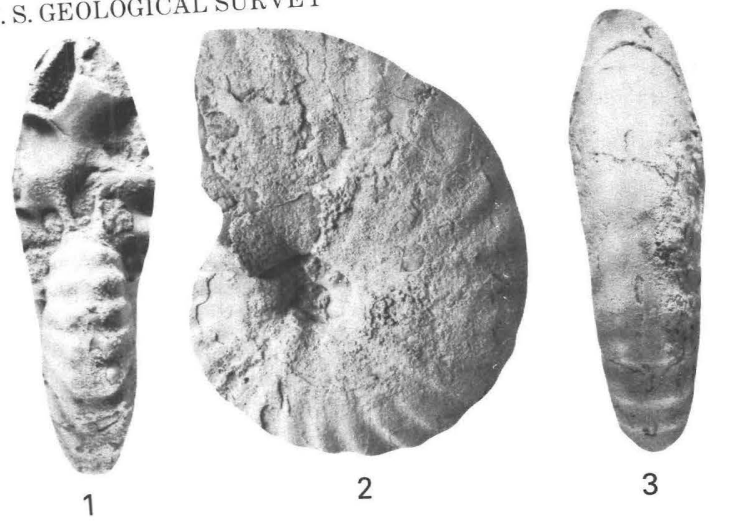

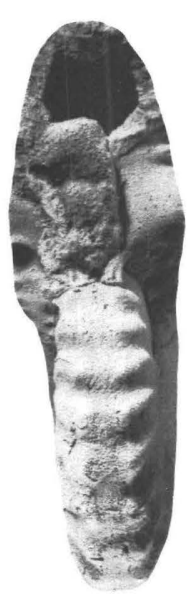

8

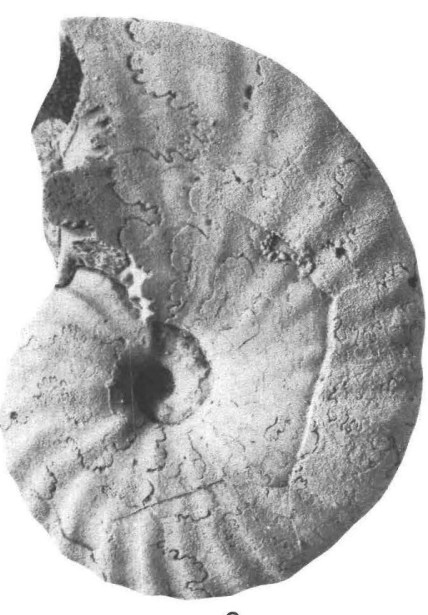

9

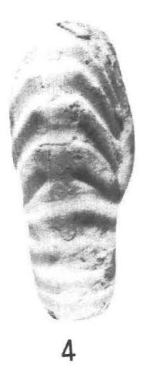

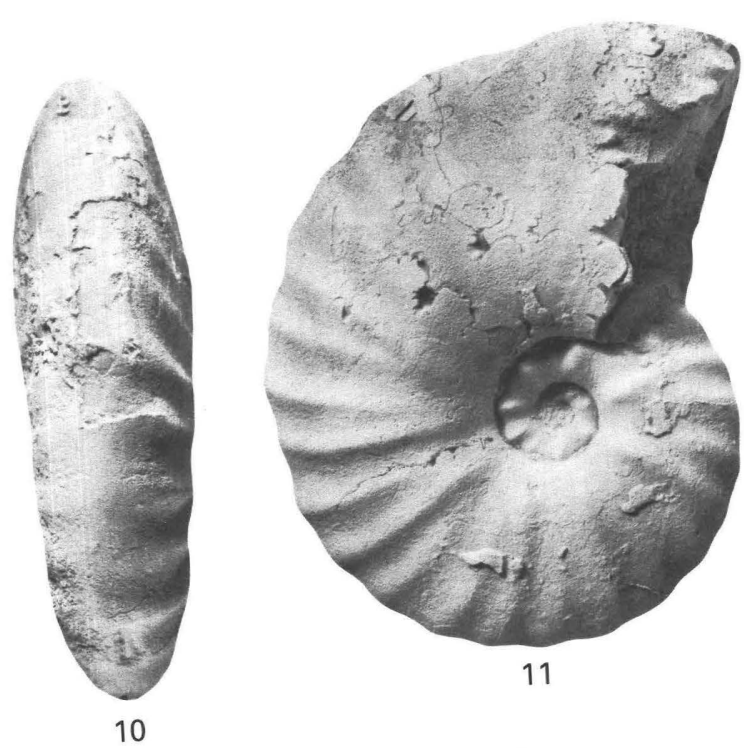
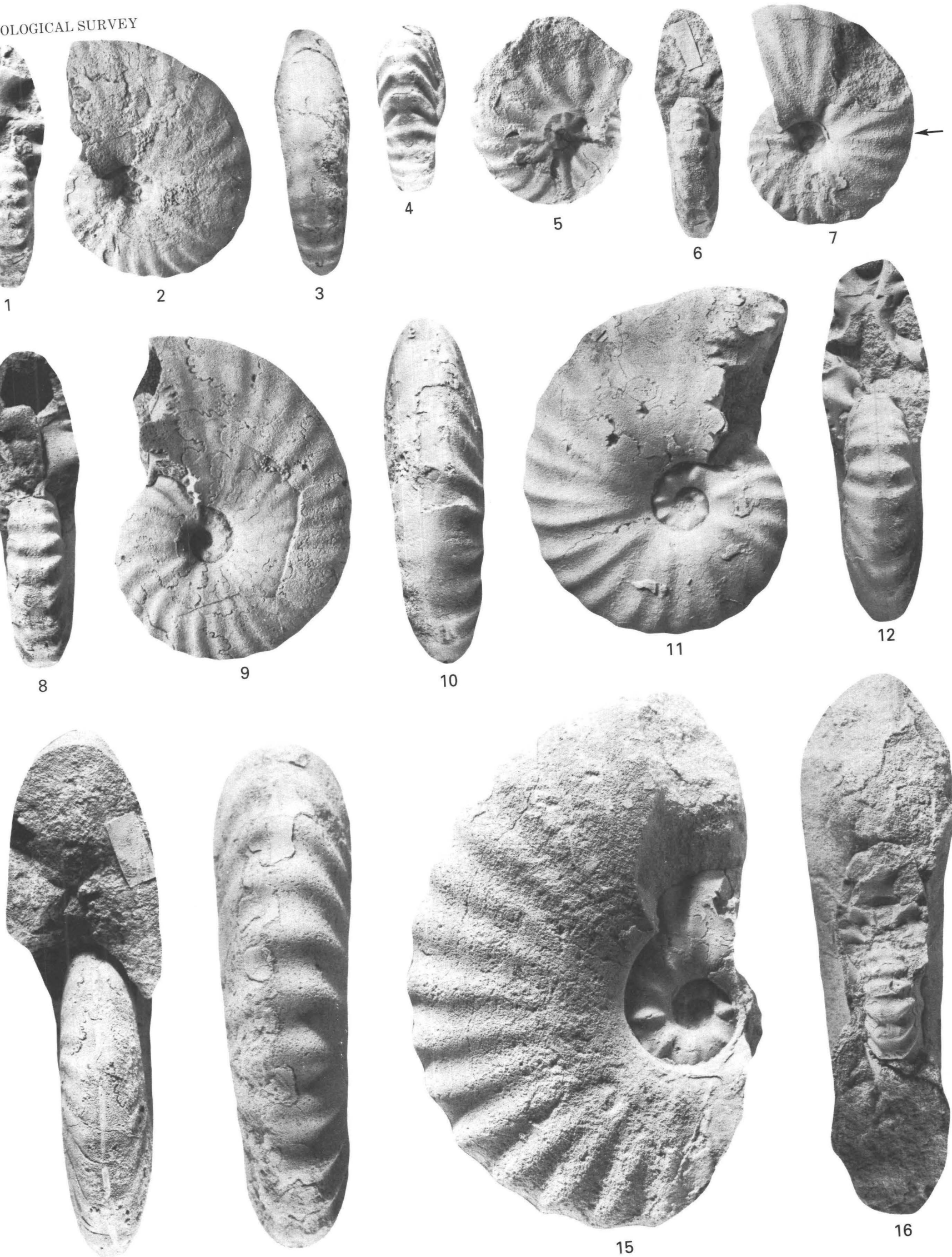
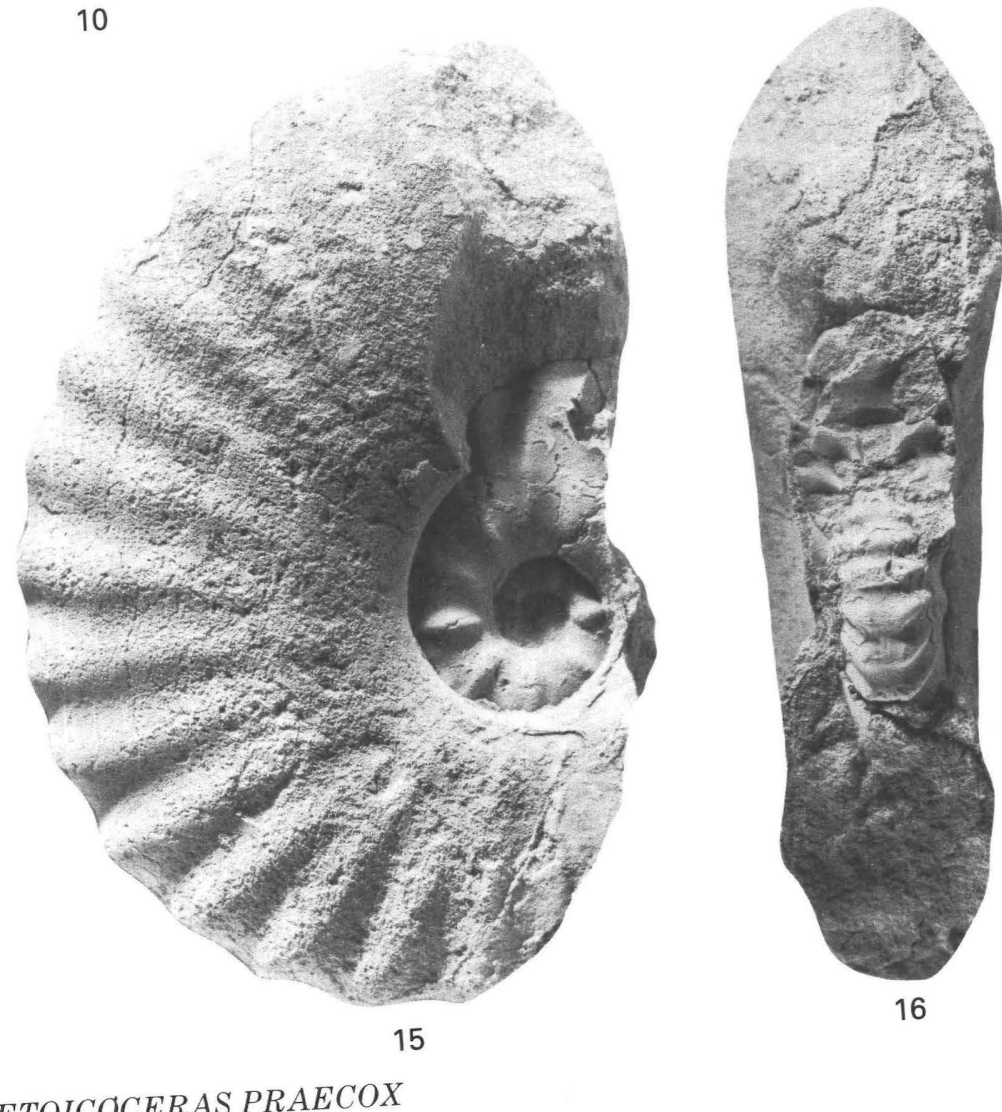


\section{PLATE 3}

\section{Metoicoceras praecox Haas (p. B2)}

[All figures natural size. Arrows point to base of body chambers]

Figures 1-6. From the basal part of the Cody Shale at U.S. Geological Survey Mesozoic locality 21850 in the SE1/4 sec. 9, T. 53 N., R. 92 W., Big Horn County, Wyoming.

1-3. Hypotype USNM 427926.

4-6. Hypotype USNM 427936. 

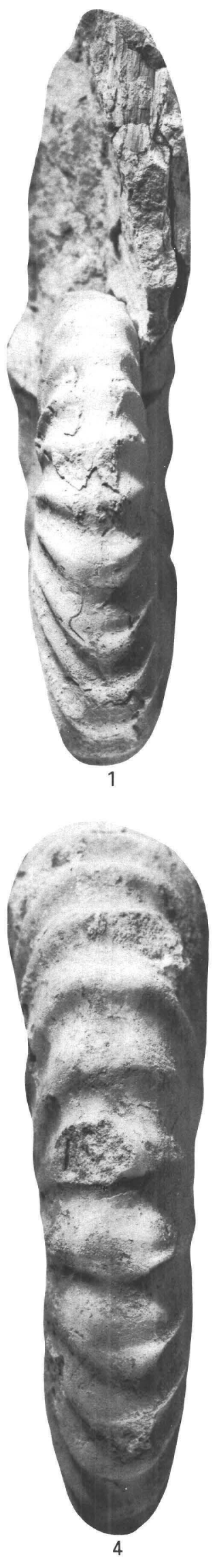
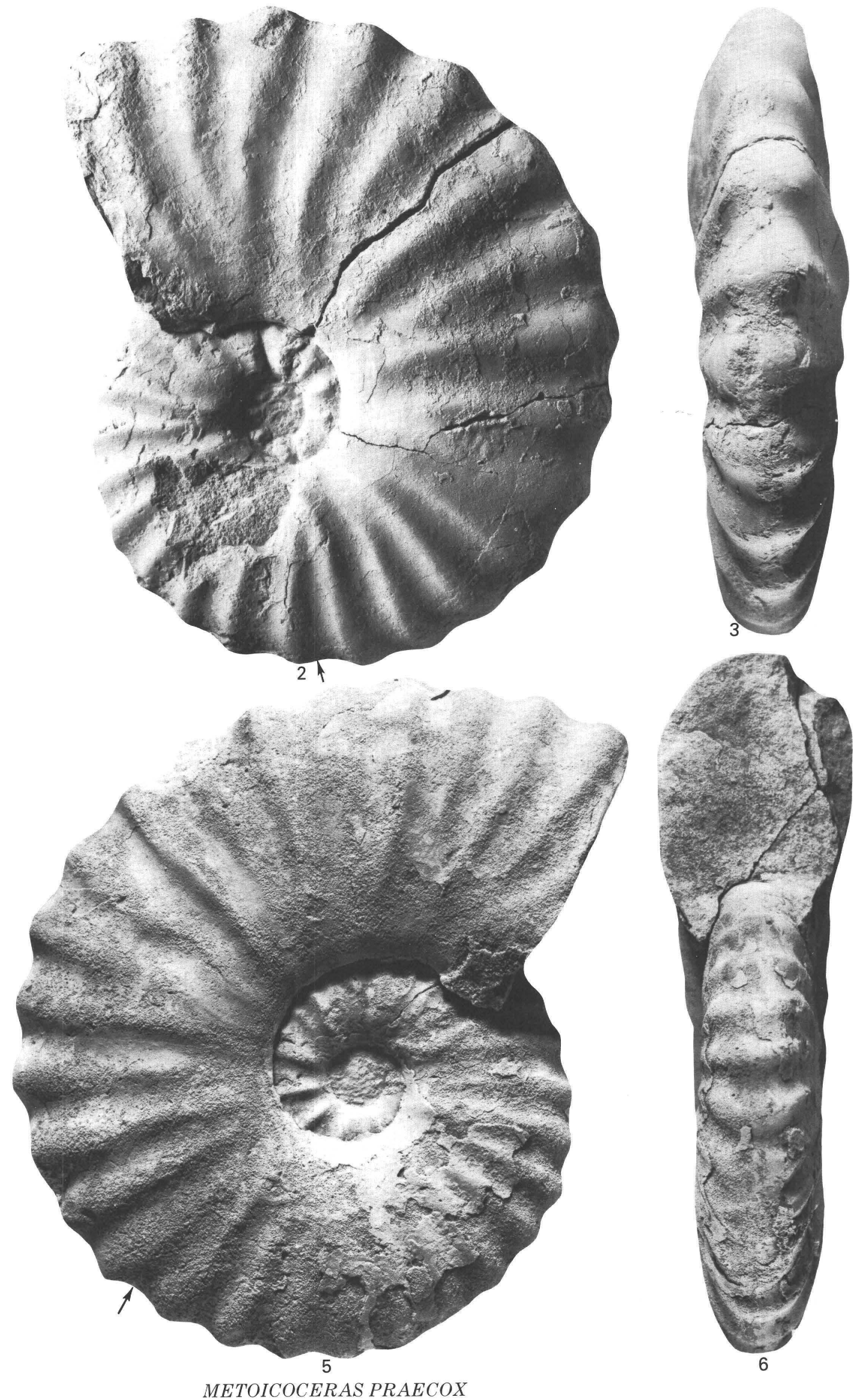


\section{PLATE 4}

\section{Metoicoceras sp. A and Metoicoceras mosbyense Cobban}

[All figures natural size. Arrow points to base of body chamber]

Figures 1-6. Metoicoceras sp. A (p. B4). From the Belle Fourche Shale at U.S. Geological Survey Mesozoic locality D5947 about 4.8 km south of Upton in the NW1/4 sec. 14, T. 47 N., R. 65 W., Weston County, Wyoming.

1, 2. Figured specimen USNM 423750.

3, 4. Figured specimen USNM 423748.

5, 6. Figured specimen USNM 423749.

7, 8. Metoicoceras mosbyense Cobban (p. B8). Hypotype 427948, from the Mosby Sandstone Member of the Belle Fourche Shale at U.S. Geological Survey Mesozoic locality 21486 about $1.6 \mathrm{~km}$ southwest of Yellow Water Reservoir in the NE1/4 sec. 14, T. 13 N., R. 25 E., Petroleum County, Montana. 

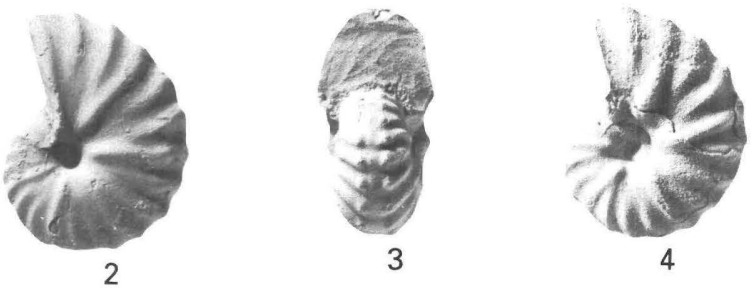

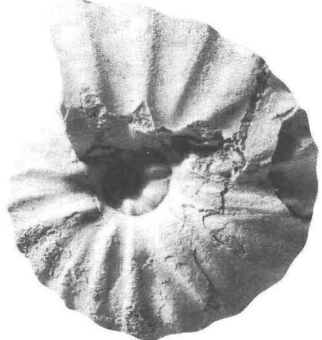

5

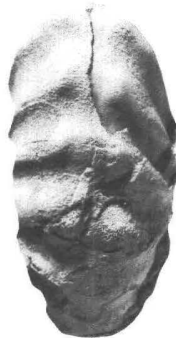

6
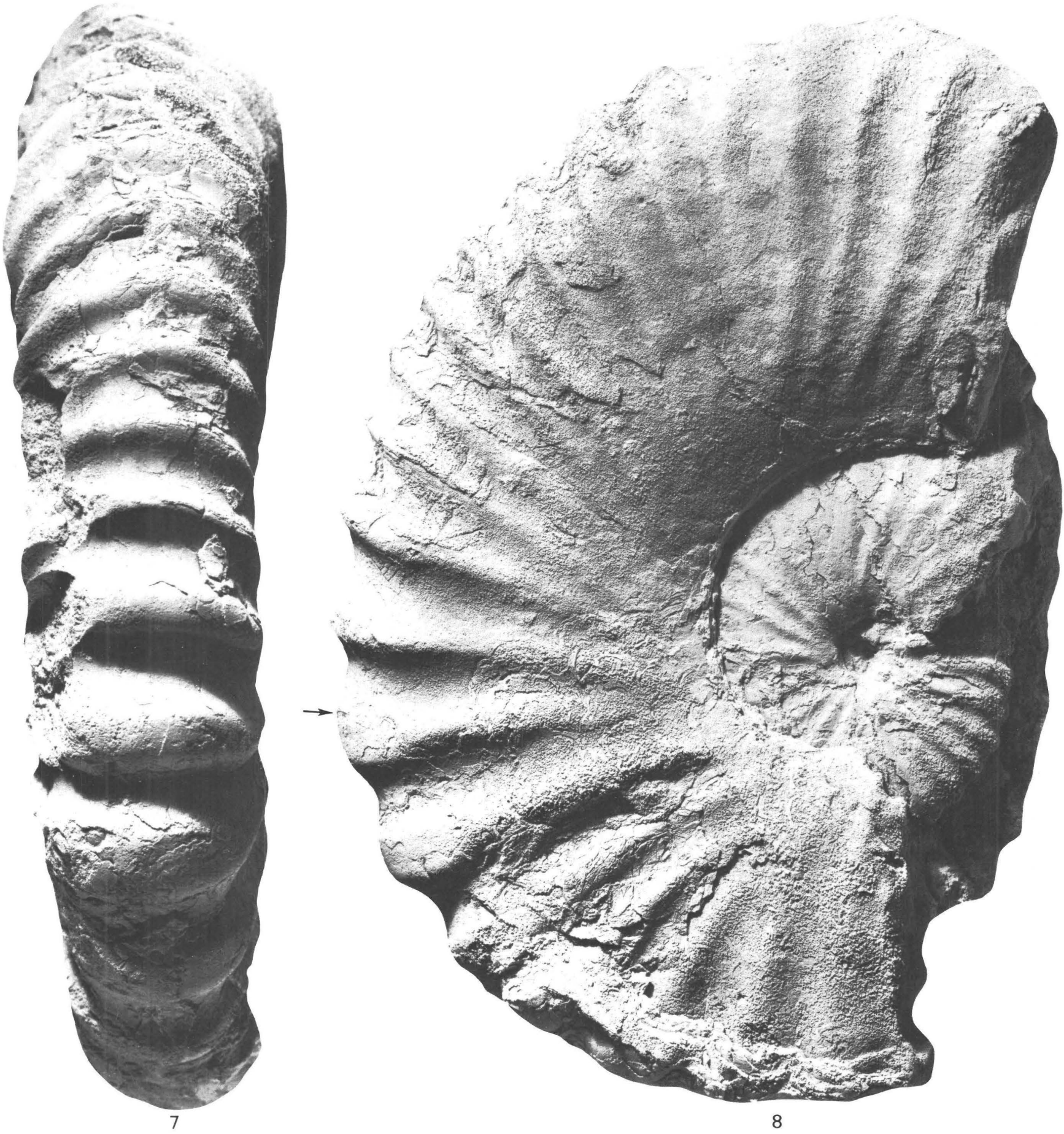

METOICOCERAS SP. AND METOICOCERAS MOSBYENSE 


\section{PLATE 5}

Metoicoceras mosbyense Cobban, Metoicoceras aff. praecox Haas, Metoicoceras swallovi (Shumard), and Metoicoceras latoventer Stephenson

[All figures natural size except as indicated. Arrows point to base of body chambers]

Figures 1-3, 15-17. Metoicoceras mosbyense Cobban (p. B8). From the Mosby Sandstone Member of the Belle Fourche Shale at U.S. Geological Survey Mesozoic locality 21485 at Yellow Water Reservoir in the SW1/4 sec. 1, T. 13 N., R. 25 E., Petroleum County, Montana.

1-3. Hypotype USNM 427947.

15-17. Hypotype USNM 220382.

4-11. Metoicoceras aff. praecox Haas (p. B7). From the Greenhorn Formation at U.S. Geological Survey Mesozoic locality D4462 about 5.7 km south-southeast of Upton in the NE1/4 sec. 24, T. 47 N., R. 65 W., Weston County, Wyoming.

4-6. Figured specimen USNM 423756, $\times 2$.

7, 8. Figured specimen USNM 423753.

9-11. Figured specimen USNM 423754.

12-14. Metoicoceras swallovi (Shumard) (p. B9). Hypotype USNM 427943, from the Templeton Member of the Woodbine Formation at U.S. Geological Survey Mesozoic locality 14546 about $13 \mathrm{~km}$ east of Arthur City, Lamar County, Texas.

18, 19. Metoicoceras latoventer Stephenson (p. B9). Hypotype USNM 427945, from the Templeton Member of the Woodbine Formation at U.S. Geological Survey Mesozoic locality 17183 about $4.5 \mathrm{~km}$ southeast of the center of Whitesboro, Grayson County, Texas. 


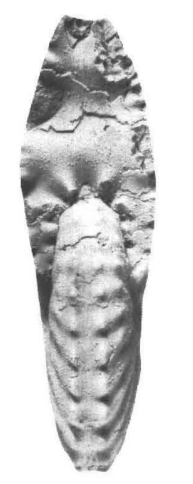

1

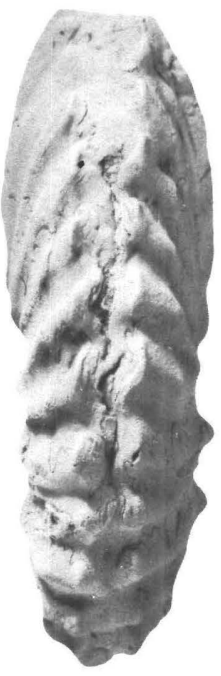

12

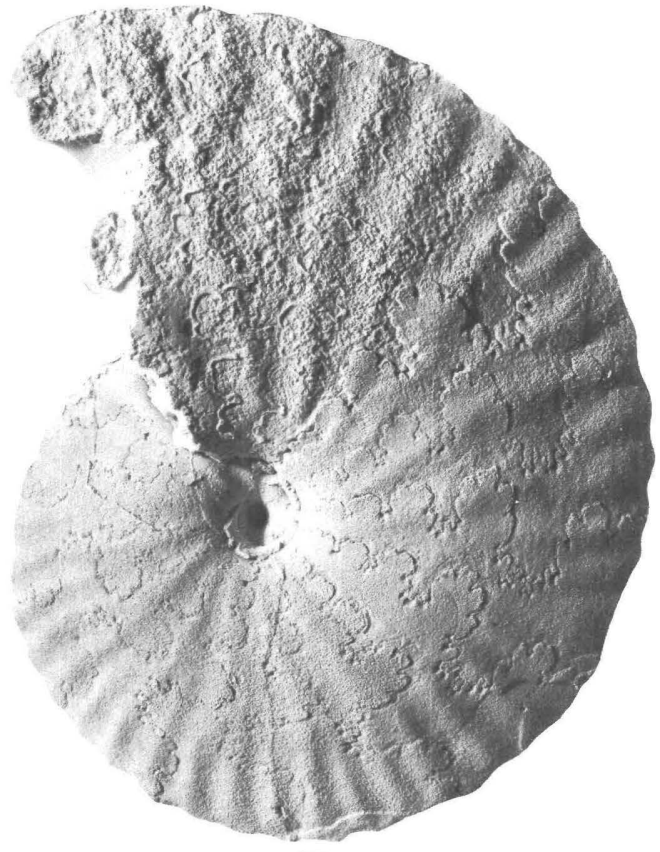

17

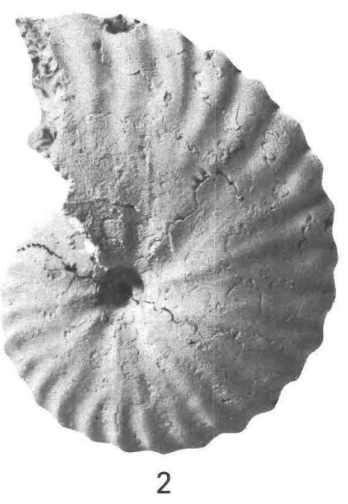

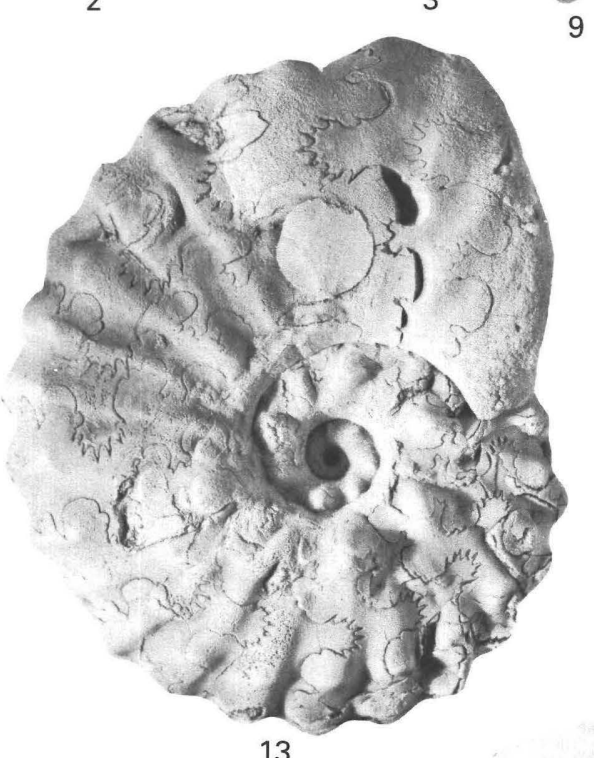

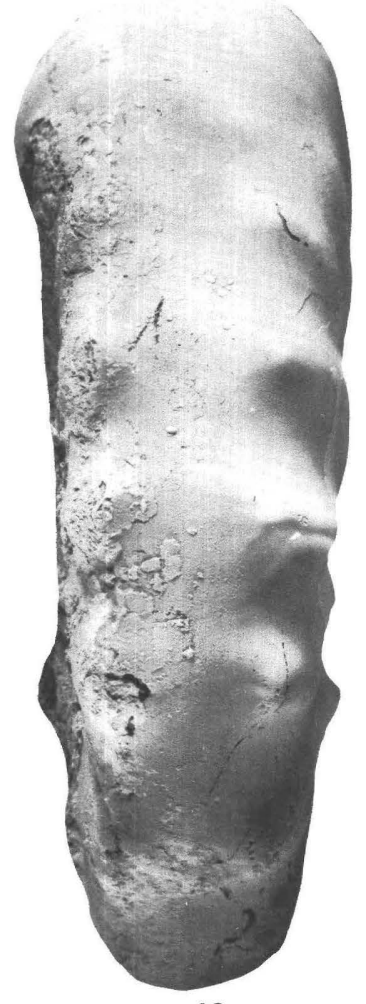

14
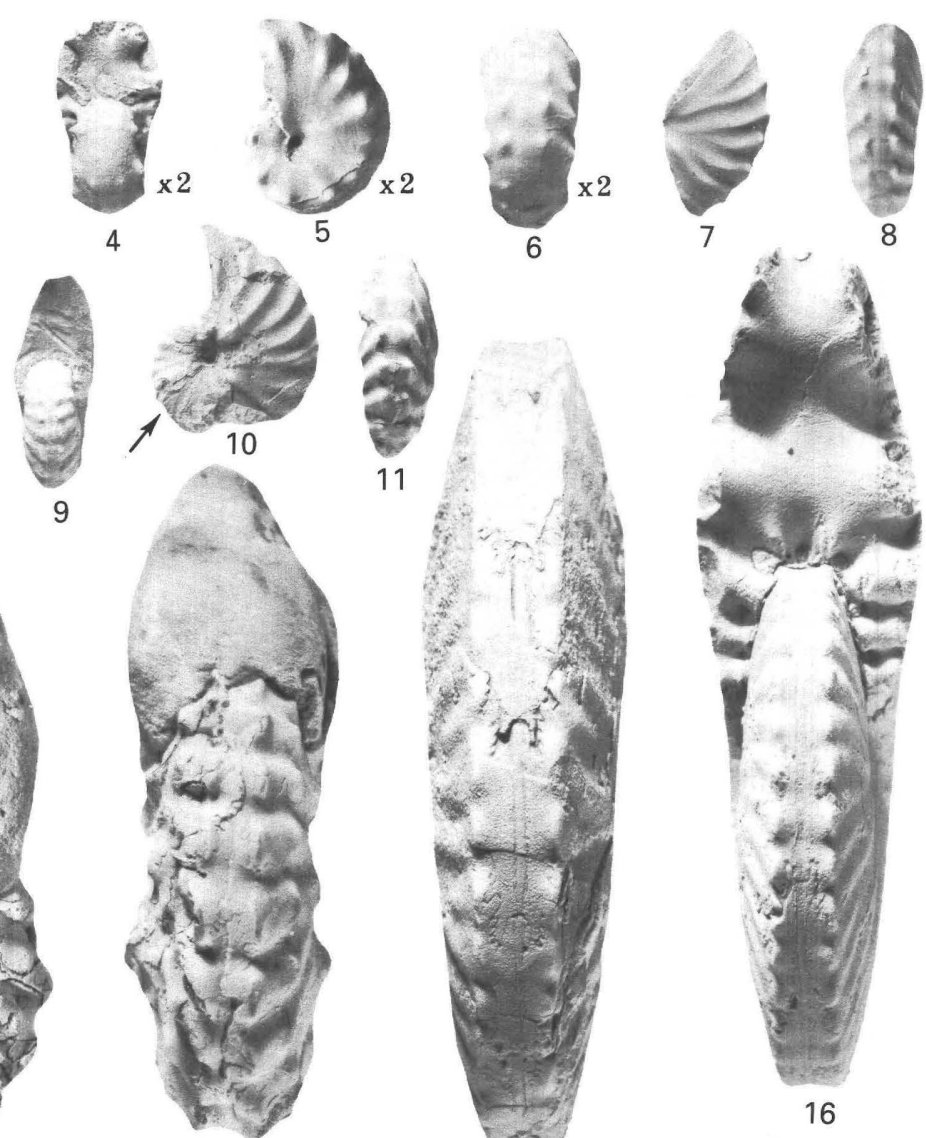

11
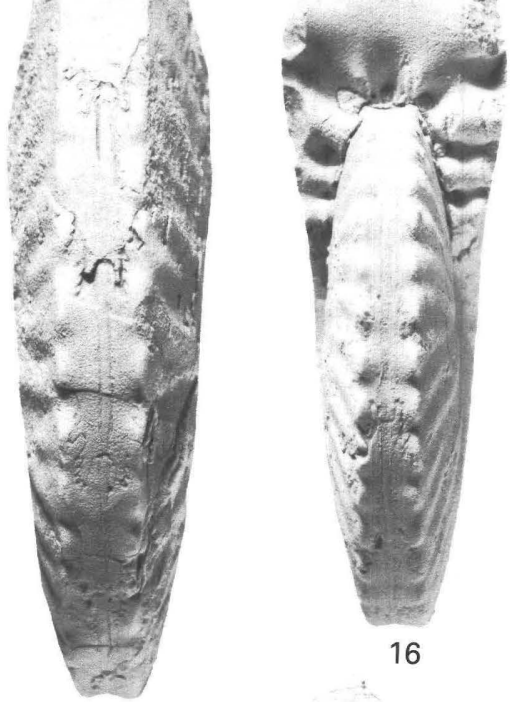

16

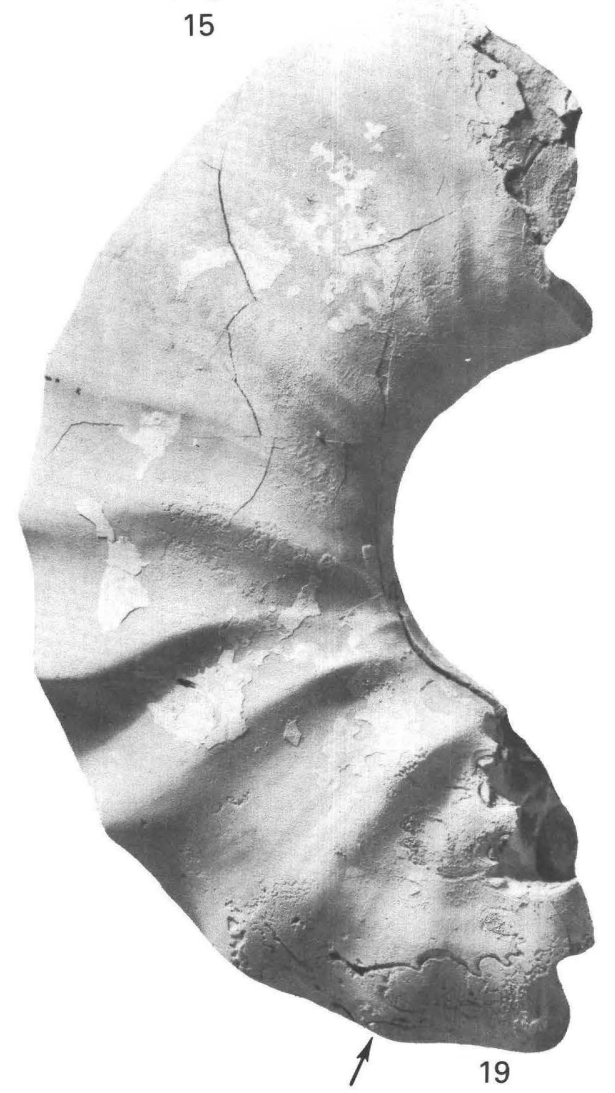

METOICOCERAS MOSBYENSE, METOICOCERAS AFF. PRAECOX, METOICOCERAS SWALLOVI, AND METOICOCERAS LATOVENTER 


\section{PLATE 6}

\section{Metoicoceras geslinianum (d'Orbigny), Metoicoceras frontierense Cobban, and Metoicoceras aff. frontierense}

\section{Cobban}

[All figures natural size except as indicated. Arrows point to base of body chambers]

Figures 1-10. Metoicoceras geslinianum (d'Orbigny) (p. B8).

1, 2. Hypotype USNM 425301, from the Bridge Creek Limestone Member of the Colorado Formation in the Cookes Range at U.S. Geological Survey Mesozoic locality D6842 in the N1/2N1/2 sec. 30, T. 20 S., R. 8 W., Luna County, New Mexico.

3. Hypotype USNM 425302, from the Colorado Formation in the Big Burro Mountains at U.S. Geological Survey Mesozoic locality D11529 in the NW1/4NE1/4 sec. 11, T. 18 S., R. 18 W., Grant County, New Mexico.

4, 5. Hypotype USNM $425295(\times 2$, ) from the same locality as figure 3 .

6, 7. Hypotype USNM 425298, from the same locality as figure 3.

8-10. Hypotype USNM 425299, from the same locality as figure 3.

11-15. Metoicoceras frontierense Cobban (p. B7). From the Frontier Formation at U.S. Geological Survey Mesozoic locality 23154 in the NE1/4 sec. 1, T. 43 N., R. 83 W., Johnson County, Wyoming.

11, 12. Paratype USNM 376930.

13-15. Holotype USNM 376927.

16-18. Metoicoceras aff. frontierense Cobban (p. B7). Figured specimen USNM 422701, from the Twowells Tongue of the Dakota Sandstone at U.S. Geological Survey Mesozoic locality D6173 in the NE1/4SE1/4 sec. 3, T. 10 N., R. 31 E., Apache County, Arizona. 

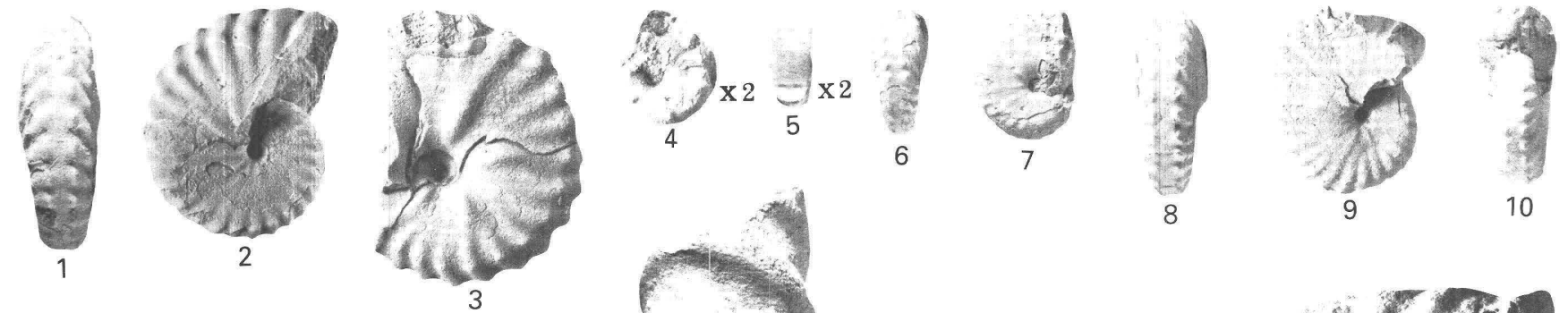

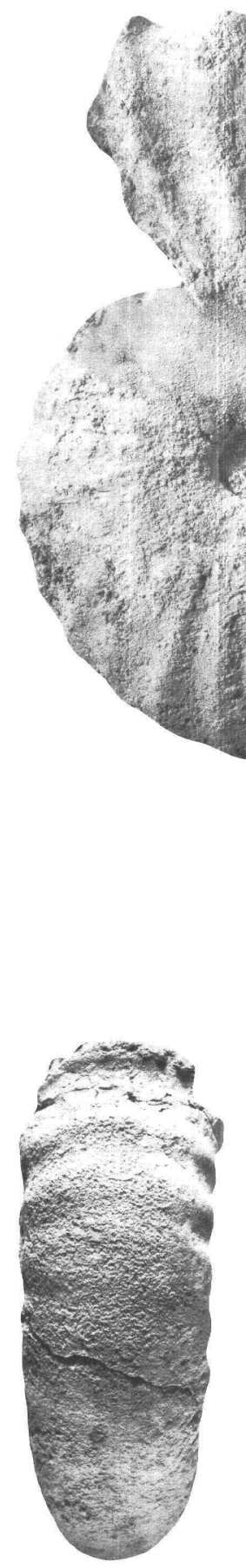

15
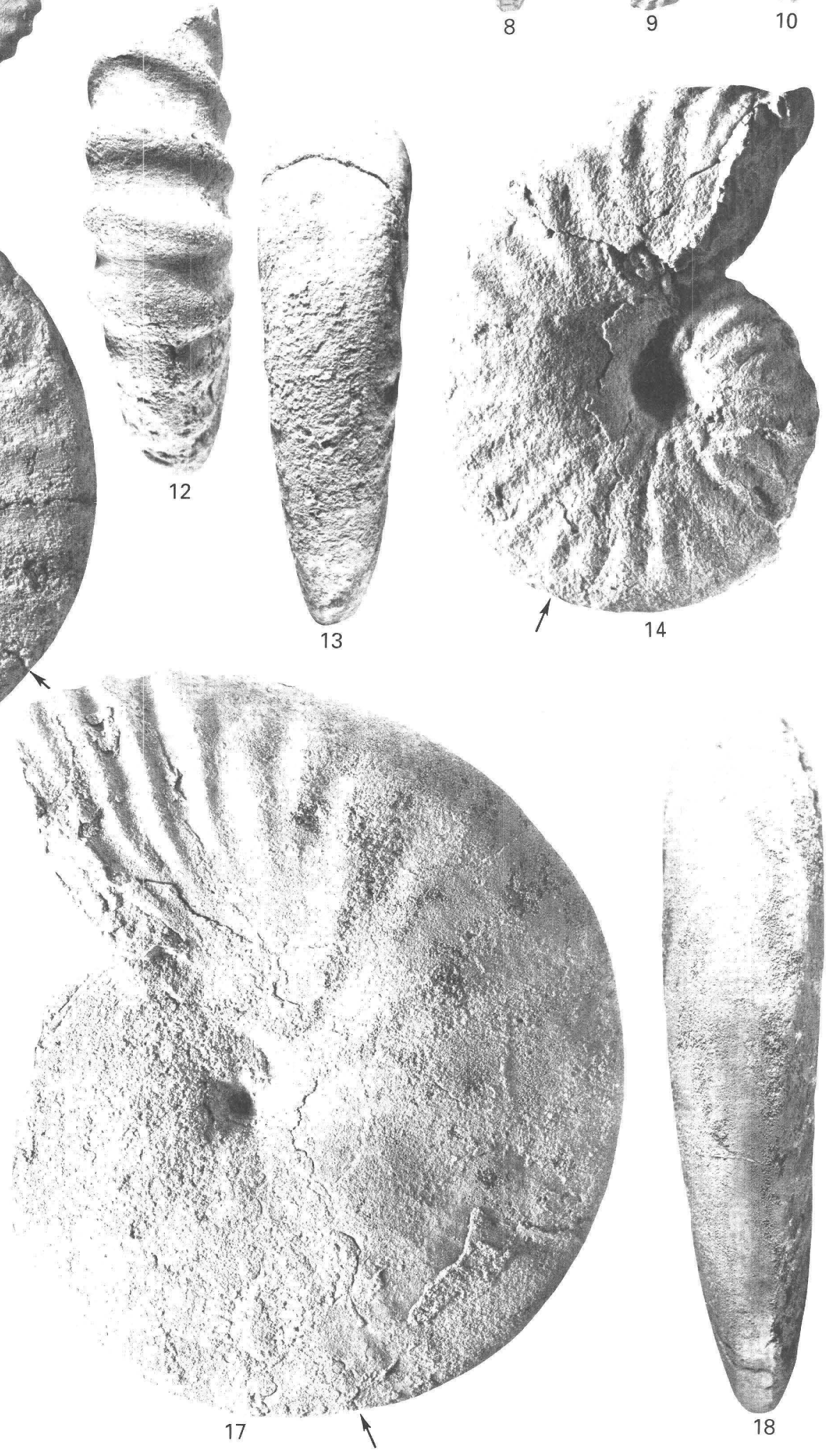

METOICOCERAS GESLINIANUM, METOICOCERAS FRONTIERENSE,

AND METOICOCERAS AFF. FRONTIERENSE 

Chapter C

\section{Baculites thomi Reeside, 1927, an Upper Cretaceous Ammonite in the Western Interior of the United States}

BY WILLIAM A. COBBAN and W. JAMES KENNEDY

Description and illustrations of a distinctive marker species

from rocks at the Santonian-Campanian boundary

U.S. GEOLOGICAL SURVEY BULLETIN 1934

SHORTER CONTRIBUTIONS TO PALEONTOLOGY AND STRATIGRAPHY 



\title{
CONTENTS
}

\author{
Abstract C1 \\ Introduction $\mathbf{C 1}$ \\ Localities of Collections C1 \\ Published Records of Baculites thomi Reeside C1 \\ Montana C1 \\ Wyoming C5 \\ New Mexico C5 \\ Age of Baculites thomi Reeside C5 \\ Systematic Paleontology C5 \\ Family BACULITIDAE Gill, 1871 C5 \\ Genus BACULITES Lamarck. 1799 C5 \\ Baculites thomi Reeside C5 \\ References Cited C7
}

\section{PLATES}

[Plates follow references cited]

1, 2. Baculites thomi Reeside

\section{FIGURES}

1. Map of part of the Western Interior of the United States showing localities of Baculites thomi Reeside described in table 1 C2

2. Drawing showing sutures and whorl sections of Baculites thomi Reeside $\mathbf{C 6}$

\section{TABLES}

1. Localities at which Baculites thomi fossils were collected $\mathbf{C 3}$

2. Average angle of taper and average number of flank and ventral ribs per height of Baculites thomi Reeside C7 



\title{
Baculites thomi Reeside, 1927, an Upper Cretaceous Ammonite in the Western Interior of the United States
}

\author{
By William A. Cobban ${ }^{1}$ and W. James Kennedy ${ }^{2}$
}

\begin{abstract}
The heteromorphic ammonite Baculites is an important marker fossil for much of the marine Upper Cretaceous of the Western Interior of the United States. Baculites thomi Reeside, 1927, is a previously poorly known species that is herein redescribed from well-preserved material from the top of the Kevin Member of the Marias River Shale in northwestern Montana. The species ranges from the upper Santonian into the lower Campanian.
\end{abstract}

\section{INTRODUCTION}

Baculites thomi Reeside (1927a, p. 13, pl. 12, figs. 9-14) was based on two specimens, the holotype and a paratype from the Telegraph Creek Formation in southcentral Montana. Since the publication of Reeside's work, $B$. thomi has been recorded in a few papers and illustrated in only two. The species has a distinctive ornament, a fairly brief time span, and a wide geographic distribution; accordingly, $B$. thomi can serve as a good index fossil.

Baculites thomi originally was described briefly and illustrated by three retouched views of the holotype and by the suture of the paratype. We herein redescribe the species on the basis of abundant well-preserved material from one locality (U.S. Geological Survey (USGS) Mesozoic locality 21419) in Toole County in northwestern Montana. The specimens include nearly all growth stages, and some adults have complete apertures. The present study reveals that $B$. thomi descended from $B$. codyensis Reeside of late Coniacian-early Santonian age and ranged through rocks of late Santonian-early Campanian age.

All specimens illustrated in this report are kept in the U.S. National Museum of Natural History (USNM), Washington, D.C., where they have USNM catalog numbers.

\footnotetext{
Manuscript approved for publication February 27, 1990.

${ }^{1}$ U.S. Geological Survey, Denver, CO 80225.

${ }^{2}$ Geological Collections, University Museum, Parks Road, University of Oxford, Oxford OX1 3PW. U.K.
}

R.E. Burkholder (retired from the USGS) took the photographs. Kennedy acknowledges the financial support of the Natural Environment Research Council (U.K.) and the technical assistance of the staff of the Geological Collections, Oxford University Museum, and the Department of Earth Sciences, Oxford, U.K.

\section{LOCALITIES OF COLLECTIONS}

Localities at which Baculites thomi has been collected in the Western Interior are shown in text figure 1 and are numbered from north to south. The USGS Mesozoic locality number, the collector(s), the year of collection, the locality, and the stratigraphic assignment are given in table 1 .

\section{PUBLISHED RECORDS OF BACULITES THOMI REESIDE}

\section{Montana}

The types of Baculites thomi came from the Elk Basin Sandstone Member of the Telegraph Creek Formation in the type area of that formation west of Hardin in Big Horn County in south-central Montana, where the species was associated with Desmoscaphites bassleri Reeside (Reeside, 1927 a, p. 14, unnumbered table) (text fig. 1, loc. 19).

Cobban (1950, p. 1900) also noted the presence of $B$. thomi with $D$. bassleri in the type area of the Telegraph Creek Formation and listed the following additional fossils from the formation (some names have been updated herein): Scaphites leei Reeside (form II of Cobban, 1969, p. 15), Haresiceras mancosense (Reeside), B. haresi Reeside, $B$. aquilaensis Reeside, and Inoceramus (Sphenoceramus) lundbreckensis McLearn.

East of Hardin (text fig. 1), the Eagle Sandstone, which overlies the Telegraph Creek Formation, grades into siltstone and mudstone that contains beds of ferruginous and calcareous concretions. This time equivalent of the Eagle 


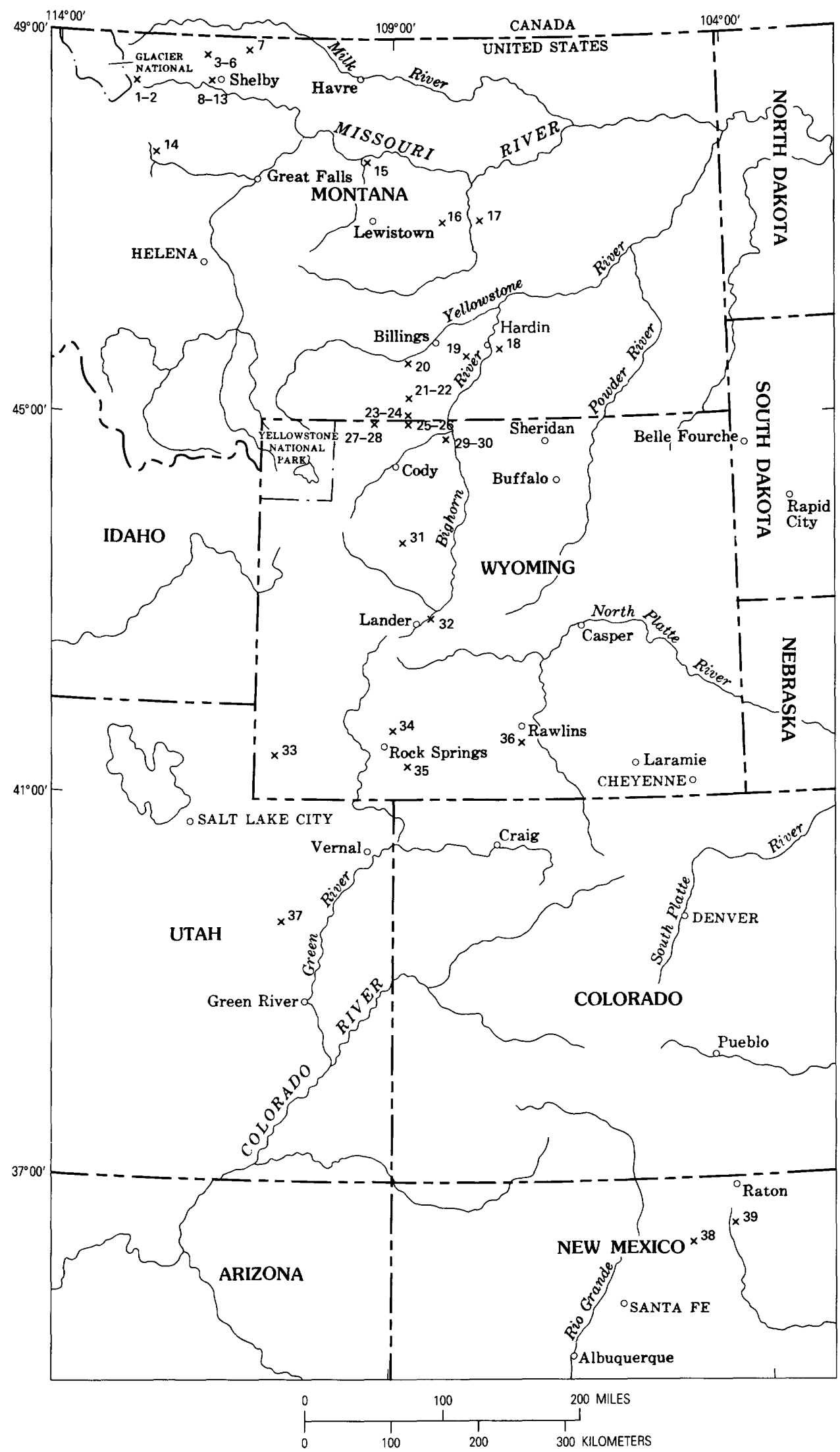

Figure 1. Part of the Western Interior of the United States showing localities of Baculites thomi Reeside described in table 1. 
Table 1. Localities at which Baculites thomi fossils were collected

\begin{tabular}{|c|c|c|}
\hline $\begin{array}{l}\text { Locality on } \\
\text { text figure } \\
\qquad 1\end{array}$ & $\begin{array}{l}\text { USGS } \\
\text { Mesozoic } \\
\text { locality }\end{array}$ & $\begin{array}{l}\text { Collector(s) and year of collection, description of locality, } \\
\text { and stratigraphic assignment }\end{array}$ \\
\hline $1 \ldots \ldots \ldots \ldots \ldots$ & 24738 & $\begin{array}{l}\text { C.E. Erdmann, 1953. NW1/2NW1/2 sec. } 8 \text {, T. } 32 \text { N., R. } 12 \text { W., Glacier County, Montana. Tele- } \\
\text { graph Creek Formation. }\end{array}$ \\
\hline 2. . & 24739 & $\begin{array}{l}\text { C.E. Erdmann, 1953. NW } 1 / 2 \text { SE } 1 / 2 \text { sec. 4, T. } 32 \text { N., R. } 12 \text { W., Glacier County, Montana. Tele- } \\
\text { graph Creek Formation. }\end{array}$ \\
\hline $3 \ldots \ldots \ldots \ldots \ldots$ & 11995 & $\begin{array}{l}\text { A.J. Collier and R.G. Lusk, 1923. Sec. 17, T. } 35 \text { N., R. } 3 \text { W., Toole County, Montana. Mar- } \\
\text { ias River Shale, from } 6 \text { m below top. }\end{array}$ \\
\hline $4 \ldots \ldots \ldots \ldots \ldots$ & 20695 & 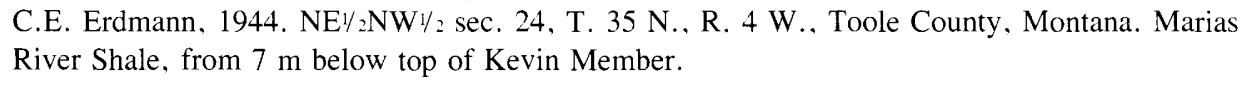 \\
\hline & D1237 & $\begin{array}{l}\text { C.E. Erdmann, R.W. Lemke, E.K. Maughan, and W.A. Cobban, 1956. NE } 1 / 2 \mathrm{NW} 1 / 2 \text { sec. } 24 . \mathrm{T} \text {. } \\
35 \mathrm{~N} . \text { R. R. } 4 \text { W., Toole County, Montana. Marias River Shale, from a thin bed of sandstone } \\
\text { about } 30 \mathrm{~m} \text { below top of Kevin Member. }\end{array}$ \\
\hline $6 \ldots \ldots \ldots \ldots \ldots$ & D5514 & $\begin{array}{l}\text { C.E. Erdmann, } 1963 . \mathrm{NE}^{1 / 2} \mathrm{NW} 1 / 2 \text { sec. } 24, \text { T. } 35 \mathrm{~N} ., \text { R. } 4 \text { W., Toole County, Montana. Marias } \\
\text { River Shale, from } 8 \mathrm{~m} \text { below top. }\end{array}$ \\
\hline & D9151 & $\begin{array}{l}\text { D.D. Rice, 1974. East of East Butte in the } \mathrm{SW} 1 / 2 \mathrm{NW} 1 / 2 \text { sec. } 13, \text { T. } 36 \text { N., R. } 5 \text { E., Liberty } \\
\text { County, Montana. Telegraph Creek Formation, from upper part. }\end{array}$ \\
\hline & 21419 & $\begin{array}{l}\text { W.A. Cobban, 1948. About } 12.9 \mathrm{~km} \text { west of Shelby in the NE } 1 / 2 \mathrm{sec} .31, \mathrm{~T} .32 \mathrm{~N} . \text {, R. } 3 \mathrm{~W} . \text {. } \\
\text { Toole County, Montana. Marias River Shale, from limestone concretions } 3 \mathrm{~m} \text { below top of } \\
\text { Kevin Member. }\end{array}$ \\
\hline $9 .$. & 21420 & $\begin{array}{l}\text { W.A. Cobban, 1948. Same locality as } 21419 \text {. Telegraph Creek Formation, from } 7.3 \text { to } 10.7 \mathrm{~m} \\
\text { above base. }\end{array}$ \\
\hline 10. & D692 & $\begin{array}{l}\text { W.L. Rohrer, 1955. SW1/2NW1/2 sec. } 31 \text {, T. } 32 \text { N., R. } 3 \text { W., Toole County, Montana Marias } \\
\text { River Shale, from } 9.1 \mathrm{~m} \text { below top. }\end{array}$ \\
\hline 11. & D693 & W.L. Rohrer, 1955. Same locality as D692. Marias River Shale, from $4.3 \mathrm{~m}$ below top. \\
\hline $12 \ldots \ldots \ldots \ldots \ldots$ & D694 & W.L. Rohrer, 1955. Same locality as D692. Marias River Shale, from $2.9 \mathrm{~m}$ below top. \\
\hline $13 \ldots$ & D696 & $\begin{array}{l}\text { W.L. Rohrer, 1955. Same locality as D692. Telegraph Creek Formation, from } 45 \mathrm{~m} \text { above } \\
\text { base. }\end{array}$ \\
\hline 14. . & D3803 & $\begin{array}{l}\text { D.L. Snow and M.R. Mudge, 1962. North Fork of Sun River, } 0.5 \text { mi north of Circle Creek, } \\
\text { Teton County, Montana. Lower part of Telegraph Creek Formation. }\end{array}$ \\
\hline 15. & 21568 & $\begin{array}{l}\text { J.B. Reeside, Jr., C.T. Moore, and W.A. Cobban, 1949; J.R. Gill and L.G. Schultz, } 1961 \text {. } \\
\text { NW } 1 / 2 \text { NW } 1 / 2 \text { sec. } 13 \text {, T. } 22 \text { N., R. } 17 \text { E., Fergus County, Montana. Telegraph Creek Forma- } \\
\text { tion, from } 12.2 \text { m below top. }\end{array}$ \\
\hline 16. & D4912 & $\begin{array}{l}\text { W.A. Cobban, 1965. Bank of McDonald Creek } 1.6 \mathrm{~km} \text { east of Winnett near center of east line } \\
\text { of sec. } 6, \text { T. } 14 \text { N., R. } 27 \text { E., Petroleum County. Montana. Telegraph Creek Formation, from } \\
\text { limestone concretions } 46 \mathrm{~m} \text { below base of cliff-forming Eagle Sandstone. }\end{array}$ \\
\hline 17. & 23896 & $\begin{array}{l}\text { W.A. Cobban, } 1952 \text {. Stream cut } 5.5 \mathrm{~km} \text { east of Mosby Post Office, in the SE } 1 / 2 \mathrm{sec} .5, \mathrm{~T} .14 \\
\text { N., R. } 31 \mathrm{E} \text {., Garfield County, Montana. Colorado Shale, from } 15 \mathrm{~m} \text { below top of Niobrara } \\
\text { Shale Member. }\end{array}$ \\
\hline 18. & 21206 & $\begin{array}{l}\text { W.A. Cobban, 1947. Eleven kilometers east of Hardin, near the center of the north line of sec. } \\
\text { 13, T. I S., R. } 34 \text { E., Big Horn County, Montana. Cody Shale, from silty limestone concre- } \\
\text { tions in Gammon Ferruginous Member. }\end{array}$ \\
\hline 19. & 10902 & $\begin{array}{l}\text { W.T. Thom, Jr., 1921. Sec. 27, T. } 1 \text { S., R. } 30 \text { E., Big Horn County, Montana. Telegraph } \\
\text { Creek Formation, from Elk Basin Sandstone Member. }\end{array}$ \\
\hline 20 . & D3302 & $\begin{array}{l}\text { J.R. Gill, 1961. SW } 1 / 2 \text { NW1/2 sec. 6, T. } 3 \text { S., R. } 23 \text { E., Carbon County, Montana. Cody Shale, } \\
\text { from Niobrara Member. }\end{array}$ \\
\hline 21. & D4223 & $\begin{array}{l}\text { J.R. Gill, 1962. SW1/2NE } 1 / 2 \text { sec. } 26, \text { T. } 7 \text { S., R. } 23 \text { E., Carbon County, Montana. Telegraph } \\
\text { Creek Formation, from top of Elk Basin Sandstone Member. }\end{array}$ \\
\hline 22. & D4637 & $\begin{array}{l}\text { J.R. Gill and C.R. Givens, 1964. NW1/2SE } 1 / 2 \text { sec. } 21 \text {, T. } 8 \text { S., R. } 24 \text { E., Carbon County, Mon- } \\
\text { tana. Telegraph Creek Formation, from middle of } 24-\mathrm{m}-\text { thick sandy unit } 62 \mathrm{~m} \text { below Elk Basin } \\
\text { Sandstone Member. }\end{array}$ \\
\hline 23. & D1445 & $\begin{array}{l}\text { W.A. Cobban, 1957. Northern side of Elk Basin in the NW1/2 sec. 35, T. } 9 \text { S., R. } 23 \text { E., Car- } \\
\text { bon County, Montana. Telegraph Creek Formation, from Elk Basin Sandstone Member. }\end{array}$ \\
\hline 24. & D1446 & $\begin{array}{l}\text { W.A. Cobban, 1957. J.R. Gill and R.K. Maynard, 1965. Butte in the NW1/2SW1/2 sec. } 35 \text {, T. } 9 \\
\text { S., R. } 23 \text { E., Carbon County, Montana. Telegraph Creek Formation, from Elk Basin Sandstone } \\
\text { Member. }\end{array}$ \\
\hline
\end{tabular}


Table 1. Localities at which Baculites thomi fossils were collected-Continued

\begin{tabular}{|c|c|c|}
\hline $\begin{array}{l}\text { Locality on } \\
\text { text figure } \\
\qquad 1\end{array}$ & $\begin{array}{l}\text { USGS } \\
\text { Mesozoic } \\
\text { locality }\end{array}$ & $\begin{array}{c}\text { Collector(s) and year of collection, description of locality, } \\
\text { and stratigraphic assignment }\end{array}$ \\
\hline $25 \ldots$ & D3295 & $\begin{array}{l}\text { J.R. Gill and L.G. Schultz, 1961. SE1/2 sec. 19, T. } 58 \text { N., R. } 99 \text { W., Park County, Wyoming. } \\
\text { Telegraph Creek Formation, from } 4.6 \mathrm{~m} \text { below top of Elk Basin Sandstone Member. }\end{array}$ \\
\hline $26 \ldots \ldots \ldots \ldots \ldots$ & D3296 & $\begin{array}{l}\text { J.R. Gill and L.G. Schultz, 1961. Same locality as D3295. Telegraph Creek Formation, from } \\
\text { top of Elk Basin Sandstone Member. }\end{array}$ \\
\hline $27 \ldots \ldots \ldots \ldots \ldots$ & D4632 & $\begin{array}{l}\text { J.R. Gill and W.A. Cobban, 1964. SW1/2 SE1/2 sec. } 26 \text {, T. } 58 \text { N., R. } 103 \text { W., Park County, } \\
\text { Wyoming. Cody Shale, from fine-grained sandstone about } 407 \mathrm{~m} \text { above base. }\end{array}$ \\
\hline $28 \ldots$ & D4635 & $\begin{array}{l}\text { J.R. Gill and W.A. Cobban, 1964. SW1/2SE1/2 sec. } 26 \text {, T. } 58 \text { N., R. } 103 \text { W., Park County, } \\
\text { Wyoming. Telegraph Creek Formation, from near top of Elk Basin Member. }\end{array}$ \\
\hline $29 .$. & D4198 & $\begin{array}{l}\text { R.E. Burkholder and W.A. Cobban, 1963. NW1/2 SE } 1 / 2 \text { sec. } 29 \text {, T. } 55 \text { N., R. } 95 \text { W., Big Horn } \\
\text { County, Wyoming. Cody Shale, from unit of large, brown, calcareous sandstone concretions. }\end{array}$ \\
\hline $30 \ldots \ldots \ldots \ldots \ldots$ & D4199 & $\begin{array}{l}\text { R.E. Burkholder and W.A. Cobban, 1963. SW } 1 / 2 \text { sec. } 20 \text {, T. } 55 \text { N., R. } 95 \text { W., Big Horn } \\
\text { County, Wyoming. Cody Shale, same stratigraphic unit as D } 4198 \text {. }\end{array}$ \\
\hline $31 \ldots$ & 21752 & $\begin{array}{l}\text { J.B. Reeside, Jr., J.D. Love, M.L. Troyer, and W.R. Keefer, 1949. NE } 1 / 2 \text { SW } 1 / 2 \text { sec. } 22 \text {, T. } 6 \\
\text { N., R. } 1 \text { W., Fremont County, Wyoming. Cody Shale, from a sandstone unit } 870 \mathrm{~m} \text { above } \\
\text { base. }\end{array}$ \\
\hline 32. & 1550 & $\begin{array}{l}\text { J.B. Reeside, Jr., J.D. Love, R.M. Thompson, and M.L. Troyer, } 1949 . \text { NW1/2 SW1/2 sec. 4, T. } \\
33 \text { N., R. } 98 \text { W., Fremont County, Wyoming. Cody Shale, from } 281 \mathrm{~m} \text { below top. }\end{array}$ \\
\hline $33 \ldots$ & D3114 & $\begin{array}{l}\text { J.H. Smith, } 1961 . \mathrm{NE} y_{2} \text { sec. } 21, \text { T. } 17 \text { N., R. } 117 \text { W., Uinta County, Wyoming. Hilliard } \\
\text { Shale, from a bed of sandstone } 336 \mathrm{~m} \text { below base of Lazeart Sandstone Member of Adaville } \\
\text { Formation. }\end{array}$ \\
\hline $34 .$. & D2221 & $\begin{array}{l}\text { J.H. Smith, } 1959 . \mathrm{SE}^{1 / 2} \mathrm{SE} 1 / 2 \text { sec. } 5, \text { T. } 20 \text { N., R. } 104 \mathrm{~W} \text {., Sweetwater County, Wyoming. Blair } \\
\text { Formation, from sandstone } 30 \text { to } 38 \mathrm{~m} \text { below top. }\end{array}$ \\
\hline $35 \ldots \ldots \ldots \ldots \ldots$ & D6406 & $\begin{array}{l}\text { J.R. Gill, 1967. Center of sec. } 33, \text { T. } 17 \text { N., R. } 102 \text { W., Sweetwater County, Wyoming. Rock } \\
\text { Springs Formation, from top of Chimney Rock Tongue. }\end{array}$ \\
\hline $36 \ldots \ldots \ldots$ & D3051 & $\begin{array}{l}\text { J.H. Smith, } 1961 . \mathrm{SE}^{1 / 2} \mathrm{SW} 1 / 2 \text { sec. } 23, \text { T. } 19 \text { N., R. } 88 \text { W., Carbon County, Wyoming. Steele } \\
\text { Shale, from } 55 \mathrm{~m} \text { above base. }\end{array}$ \\
\hline 37. & D2126 & $\begin{array}{l}\text { A.D. Zapp, 1959. NW1/2NE1/2 sec. } 22 \text {, T. } 13 \text { S., R. } 10 \text { E., Carbon County, Utah. Mancos } \\
\text { Shale, from about } 60 \mathrm{~m} \text { below base of Panther Tongue of Star Point Sandstone. }\end{array}$ \\
\hline $38 \ldots$ & D11425 & $\begin{array}{l}\text { G.R. Scott, 1980; E.A. Merewether, R.E. Burkholder, and W.A. Cobban, 1984. Urraca Mesa } \\
\text { in the SE } 1 / 2 \text { SW } 1 / 2 \text { sec. } 7 \text {, T. } 25 \text { N., R. } 19 \text { E., Colfax County, New Mexico. Niobrara Forma- } \\
\text { tion, from upper shale unit of the Smoky Hill Shale Member. }\end{array}$ \\
\hline $39 \ldots$ & D11597 & $\begin{array}{l}\text { G.R. Scott, 1981. Southern bank of Tinaja Creek in the SW } 1 / 2 \text { NE } 1 / 2 \text { sec. } 26, \text { T. } 28 \text { N., R. } 23 \\
\text { E. Colfax County, New Mexico. Niobrara Formation, from upper shale unit of Smoky Hill } \\
\text { Shale Member. }\end{array}$ \\
\hline
\end{tabular}

${ }^{1} \mathrm{D}$ indicates Denver Mesozoic invertebrate locality numbers; all others are Washington, D.C., Mesozoic invertebrate locality numbers.

Sandstone is known as the Gammon Ferruginous Member of the Cody Shale (Cobban, 1964, p. 8). A sandy unit in the Gammon Member contains $B$. thomi along with a large and varied molluscan fauna that includes a late form of $S$. hippocrepis (Cobban, 1969, form III), B. haresi, B. aquilaensis, and Inoceramus (Endocostea) cf. barabini Morton (names updated) (Richards, 1955, p. 60; Knechtel and Patterson, 1956, p. 33). Farther north, in central Montana, $B$. thomi has been recorded from $15 \mathrm{~m}$ below the top of the Colorado Shale, where it is associated with an early form of S. leei Reeside (Cobban, 1969, form I), Desmoscaphites sp., and I. (Sphenoceramus) sp. (Cobban, 1964, p. 6).

Baculites thomi was reported from several localities on the Sweetgrass arch and the adjoining part of the Disturbed belt in northwestern Montana. The oldest and largest collections (text fig. 1, locs. 8, 10-12) have come from a small area 12.4 to $13.6 \mathrm{~km}$ west of Shelby (Cobban, 1950 , p. $1900 ; 1951$ a, p. $2195 ; 1951$ b, p. $39 ; 1964$, p. 5 ; 1969 , p. 14), where excellent specimens of $B$. thomi were found near the top of the Kevin Member of the Marias River Shale, which underlies sandy beds assigned to the Telegraph Creek Formation. Important fossils associated with $B$. thomi include the following (names updated): $S$. leei (Cobban, 1969, form I), D. erdmanni Cobban, Clioscaphites novimexicanus (Reeside), and I. (S.) lundbreckensis. One of these specimens of $B$. thomi was illustrated (Cobban, 1955b, pl. 2, fig. 4). B. thomi was also reported from this part of the Marias River Shale farther north (Collier, 1929 , p. 72; Cobban and others, 1976, p. 55, 56) (text fig. 1, locs. 3-6). The lower part of the Telegraph Creek Formation also contains $B$. thomi at the first locality (Cobban, 1950, p. 1900; 1955a, p. 114; 1964, p. 5) (text 
fig. 1 , locs. 9, 13) as well as farther west in the Disturbed belt (Mudge, 1972, p. 72) (text fig. 1, loc. 14). The following molluscan fossils were found with $B$. thomi (names updated): $S$. leei (Cobban, 1969, form II), Haresiceras (Mancosiceras) mancosense (Reeside), $D$. bassleri Reeside, B. haresi, and I. (S.) lundbreckensis.

\section{Wyoming}

Baculites thomi has been recorded from Wyoming in only four reports. The species was noted in the upper or sandy member of the Cody Shale on the northern side of the Wind River Basin (text fig. 1, loc. 31) by Yenne and Pipiringos (1954) and by Keefer and Troyer (1956, 1964), where it was associated with Desmoscaphites bassleri. Baculites thomi was also reported by Yenne and Pipiringos from the sandy member of the Cody Shale on the southern side of the Wind River Basin. where it was found with Scaphites hippocrepis (Cobban, 1969, form I), Haresiceras montanaense (Reeside), and B. haresi (names updated). Smith (1965, p. 20) reported $B$. thomi farther south on the Rock Springs uplift (text fig. 1, loc. 34), where the species was found in a sandstone unit about 30 to $38 \mathrm{~m}$ below the top of the Blair Formation. Associated fossils include $S$. hippocrepis (Cobban, 1969, form III) and B. haresi.

\section{New Mexico}

The only report of Baculites thomi in New Mexico is from Scott and others (1986, p. 9, 17, 32, text figs. 14g, $15 f$ ) in the Raton basin (text fig. 1, locs. 38, 39). The species was found in a limestone bed in the Niobrara Formation that contains Scaphites leei I, Desmoscaphites erdmanni, Clioscaphites choteauensis Cobban, Texanites omeraensis (Reeside), Reginaites leei (Reeside), Inoceramus (Sphenoceramus) lundbreckensis, I. (Endocostea) balticus Böhm, and I. (Cordiceramus) muelleri Petrascheck).

\section{AGE OF BACULITES THOMI REESIDE}

Baculites thomi has been found with Desmoscaphites erdmanni, D. bassleri, and the late form of Scaphites hippocrepis (III). Each of the last three species is a guide to an ammonite zone in the Western Interior (Cobban, 1964, table 2; 1969, p. 6). Rocks that contain Desmoscaphites have been long assigned to the Santonian (Cobban and Reeside, 1952, unnumbered chart). These rocks contain the free-swimming crinoids Marsupites and Uintacrinus, which are considered as guides to the upper Santonian (for example, Ernst, 1963, p. 102, 105-108; 1966, p. 136, 139; 1973, p. 82, 83; Ernst and Schulz, 1974, p. 14, 24, fig. 6; Ernst and Schmid, 1975, p. 121; Klikushin, 1983, p. 103 , 104; Birkelund and others, 1984, p. 15; Bailey and others, 1984, p. 37). Although Marsupites and Uintacrinus are present with either $D$. erdmanni or D. bassleri in several of the USGS collections, these crinoids have been recorded with $D$. bassleri in only two reports (Thom and others, 1935, p. 54, 55: Keefer and Troyer, 1964, p. 88).

Although $B$. thomi is most abundant in the upper Santonian, it ranges into rocks as young as the zone of $S$. hippocrepis III, where it is scarce (Richards, 1955, p. 60 ; Knechtel and Patterson, 1956, p. 33). This late form of $S$. hippocrepis occurs in the upper part of the lower Campanian in Europe (Schmid and Ernst, 1975, p. 325, 326, fig. 2). The range of $B$. thomi is thus upper Santonian into lower Campanian, its peak development being in the Santonian.

\section{SYSTEMATIC PALEONTOLOGY}

Family BACULITIDAE Gill, 1871

Genus BACULITES Lamarck, 1799

Type species. - Baculites vertebralis Lamarck, 1801, p. 103, by subsequent designation by Meek, 1876, p. 391.

\section{Baculites thomi Reeside}

Plates 1, 2; text figure 2

1927a. Baculites thomi Reeside, p. 13, pl. 12, figs. 9-14.

1927a. Baculites asper Morton. Reeside, p. 13 (pars), pl. 10, figs. 9-12 only.

1955b. Baculites thomi Reeside. Cobban, p. 204, pl. 2, fig. 4.

1986. Baculites thomi Reeside. Scott, Cobban, and Merewether, p. 17 , figs. $14 \mathrm{~g}, 15 \mathrm{f}$.

Types. - The holotype by original designation is USNM 73315, from the Elk Basin Sandstone Member of the Telegraph Creek Formation at USGS Mesozoic locality 10902 in sec. 27, T. 1 S., R. 30 E., Big Horn County, Montana (text fig. 1, loc. 19). Hypotypes USNM 433905-433907 and 440808-440816 are from limestone concretions $3 \mathrm{~m}$ below the top of the Kevin Member of the Marias River Shale at USGS Mesozoic locality 21419 in the NE1/4 sec. 31, T. 32 N., R. 3 W., Toole County, Montana (text fig. 1 , loc. 8 ).

Diagnosis. - A baculite of moderate size characterized by a fairly stout ovate section, a small angle of taper, and conspicuous ornament of strong flank and ventral ribs. Flank ribs may be closely spaced and crescentic or more distantly spaced and nodelike. The suture is of moderate complexity for the genus.

Material.-About 300 specimens are present in the collection from locality 21419 (text fig. 1, loc. 8). These specimens range in whorl height from $3.5 \mathrm{~mm}$ to $30 \mathrm{~mm}$.

Description.-Nearly all specimens from locality 21419 are straight, although an occasional juvenile may show slight curvature (pl. 1, fig. 4). The expansion rate (taper angle) is very small for adults and slightly more for juveniles. Table 2 summarizes the expansion rates of 259 


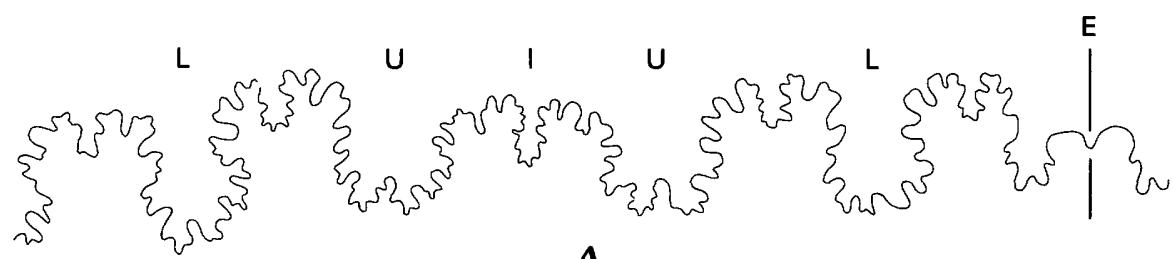

A

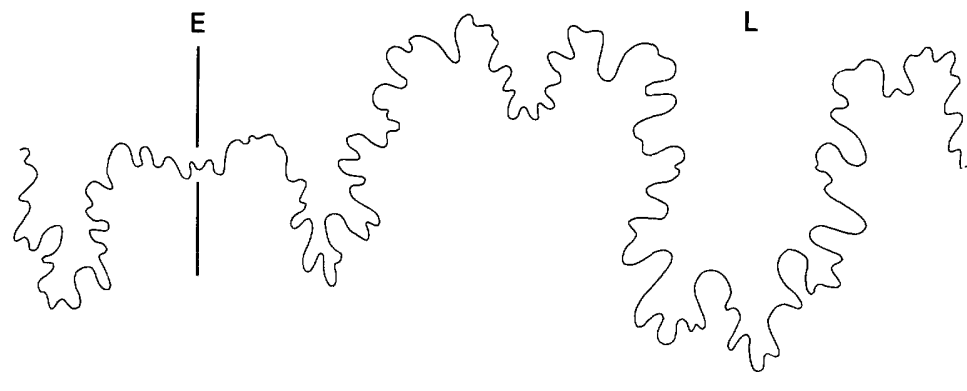

B

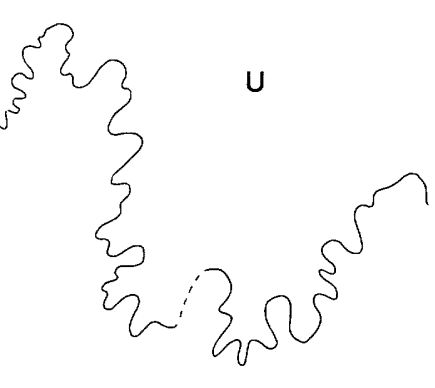

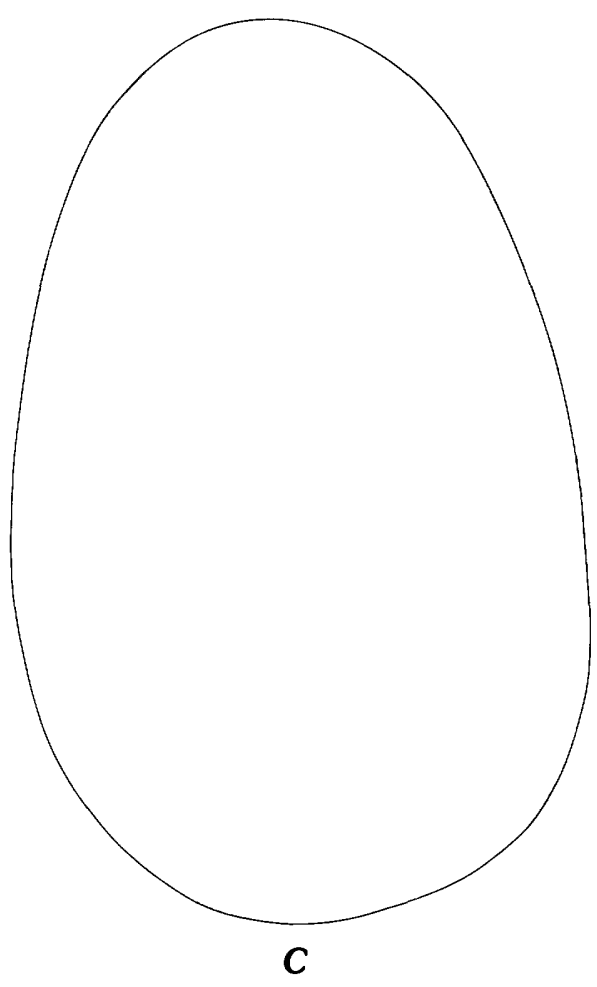

Figure 2. Sutures and whorl sections of Baculites thomi Reeside. A, Hypotype USNM 440808 at a whorl height of $9 \mathrm{~mm}$ (pl. 1, figs. 1-3). B, Hypotype USNM 440816 at a whorl height of $20 \mathrm{~mm}$ (pl. 2, figs. 7-9). C, Hypotype USNM 440814 at a whorl height of $19.3 \mathrm{~mm}$

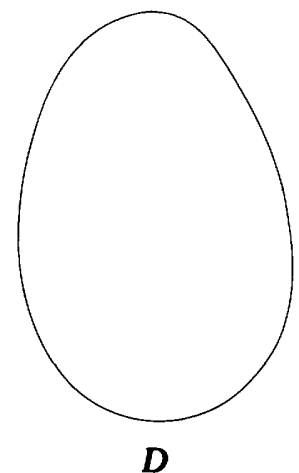

$10 \mathrm{~mm}$

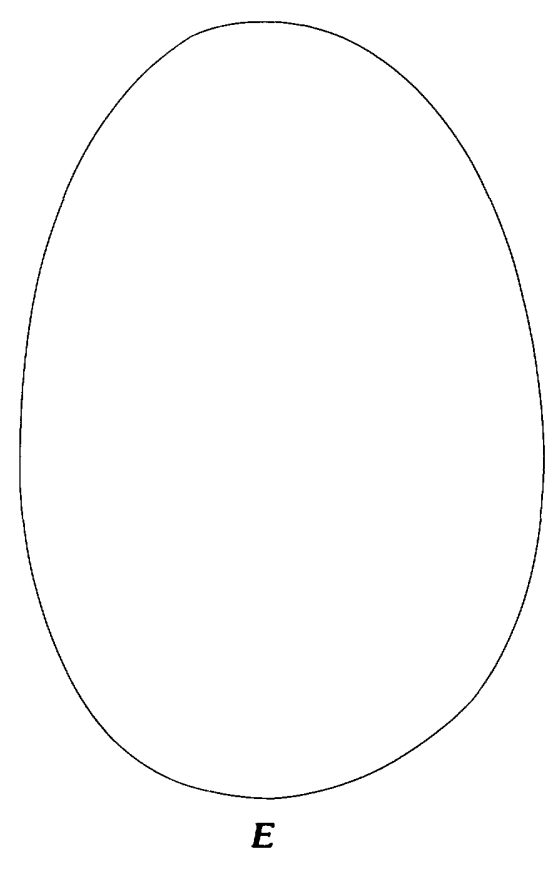

(pl. 2, figs. 1-3). D, Hypotype USNM 440808 at a whorl height of $19.8 \mathrm{~mm}$ (pl. 1, figs. 1-3). E, Hypotype USNM 433905 at a whorl height of $20 \mathrm{~mm}$ (pl. 1, figs. 13-15). $E$ is external lobe, $L$ is lateral lobe, $U$ is umbilical lobe, and $I$ is internal lobe. specimens that have whorl heights ranging from 5 to 21.9 $\mathrm{mm}$; measurements of larger specimens are too few to be meaningful.
The whorl section is a somewhat compressed oval, the venter being only slightly narrower than the dorsum (text figs. $2 C-E$ ). Flanks are very broadly rounded. 
Table 2. Average angle of taper and average number of flank and ventral ribs per height of Baculites thomi Reeside

[Number of specimens is in parentheses]

\begin{tabular}{cccc}
\hline $\begin{array}{c}\text { Whorl height } \\
(\mathrm{mm})\end{array}$ & $\begin{array}{c}\text { Taper } \\
\text { (degrees) }\end{array}$ & $\begin{array}{c}\text { Number of } \\
\text { flank ribs }\end{array}$ & $\begin{array}{c}\text { Number of } \\
\text { ventral ribs }\end{array}$ \\
\hline $5.0-5.9$ & $4.5(11)$ & $0.0(0)$ & $0.0(0)$ \\
$6.0-7.9$ & $4.7(28)$ & $.0(0)$ & $4.2(5)$ \\
$8.0-9.9$ & $4.5(42)$ & $2.0(1)$ & $3.8(13)$ \\
$10.0-11.9$ & $4.0(38)$ & $2.1(16)$ & $3.1(18)$ \\
$12.0-13.9$ & $3.0(46)$ & $2.2(24)$ & $3.2(27)$ \\
$14.0-15.9$ & $1.6(39)$ & $2.0(31)$ & $3.2(28)$ \\
$16.0-17.9$ & $1.5(32)$ & $2.0(26)$ & $2.9(28)$ \\
$18.0-19.9$ & $1.4(17)$ & $2.1(14)$ & $2.7(14)$ \\
$20.0-21.9$ & $1.3(6)$ & $2.4(6)$ & $2.9(4)$ \\
\hline
\end{tabular}

Ornament is lacking on juveniles that have whorl heights of less than $5 \mathrm{~mm}$. Ventral ribs may appear at a whorl height of $5 \mathrm{~mm}$, and flank ribs may arise at a height of $6 \mathrm{~mm}$, but ornament is usually missing on most specimens of less than $8 \mathrm{~mm}$ in whorl height. Ribs are weak, irregular in strength, and closely spaced at first (pl. 1, figs. 1-6), but they become stronger, regular, and a little more widely spaced in the later juvenile and early and middle adult growth stages (pl. 1, figs. 11-21). Ribs are crescentic (concave side forward) and cross the dorsal two-thirds of the flank. They are slightly asymmetric, much narrower than the interspaces, and spaced at two or three in a distance equal to the whorl height. The ribs project forward on the outer third of the flank and weaken on the dorsolateral shoulder; they become greatly weakened on crossing the dorsum in a broad convexity and may bear delicate growth lines and striae. Ribs strengthen markedly over the ventrolateral shoulder and venter, which they cross in a broad convexity. Occasional intercalated ribs are present, so that there may be as many as six ribs in a distance equal to the whorl height (pl. 2, fig. 3). Interspaces between ribs may bear delicate growth lines and sometimes feeble riblets; these riblets may be especially well developed on the dorsolateral and dorsal parts of the shell, and some venters develop primary plus secondary ribbing patterns ( $\mathrm{pl}$. 1, fig. 19; pl. 2, fig. 7). Co-occurring with this typical form are weakly ornamented individuals that we take to be no more than variants of the species. An occasional individual may have nearly smooth or smooth flanks and a strongly corrugated venter (pl. 1, figs. 16-18). Other specimens may have unusually strong ornament (pl. 1, figs. 11-15) on which the flank ribs are more nodelike and more distantly spaced than those on normal specimens (pl. 1, figs. 19-21). Flank ribs on the older adults weaken, but ventral ribs tend to remain strong (pl. 2, figs. 4-6). Apertures are preserved on a few adults (pl. 1, figs. 7-10). The aperture, which is concave on the flank, has a short linguoid dorsal rostrum and a long ventral rostrum that is flexed dorsally into a shallow cowl. The ventral rostrum tapers gradually and has a rounded termination; the rostrum is ornamented by five to seven low, broad, blunt ventral ribs that decline just before its rounded tip.

The suture is moderately incised (text figs. $2 A, B$ ). The external lobe (E) is broad, and the lateral (L) and umbilical $(\mathrm{U})$ lobes are symmetrically bifid and about equal in size, but they are narrower than E. The internal lobe (I) is very small. First and second lateral saddles ( $\mathrm{E} / \mathrm{L}$ and $\mathrm{L} / \mathrm{U}$ ) are symmetrically bifid and a little wider than $\mathrm{L}$.

The species is dimorphic. Several specimens that have the last few septa approximated at whorl heights of 12 to $19 \mathrm{~mm}$ are interpreted as microconchs, as are the two small adults having long curved ventral rostrums, shown on plate 1 . The large adult that has the last two septa approximated, shown on plate 2 (figs. 4-6), is interpreted as a macroconch; its whorl height at the end of the phragmocone is $28.5 \mathrm{~mm}$.

Discussion. - Baculites thomi evolved from B. codyensis Reeside (1927b, p. 4, pl. 2, figs. 6-19) of middle Coniacian to early Santonian age. Both species have strong flank ribbing, but $B$. codyensis is a smaller species that lacks the conspicuously corrugated venter of $B$. thomi.

\section{REFERENCES CITED}

Bailey, H.W., Gale, A.S.. Mortimore, R.N., Swiecicki, A., and Wood, C.J., 1984. Biostratigraphical criteria for the recognition of the Coniacian to Maastrichtian stage boundaries in the Chalk of north-west Europe, with particular reference to southern England: Geological Society of Denmark Bulletin, v. 33, pt. 1-2, p. 31-39.

Birkelund, T., Hancock, J.M., Hart, M.B., Rawson, P.F., Remane, J., Robaszynski, F., Schmid, F., and Surlyk, F., 1984, Cretaceous stage boundaries-Proposals: Geological Society of Denmark Bulletin, v. 33, pt. 1-2, p. 3-20.

Cobban, W.A., 1950, Telegraph Creek formation of Sweetgrass arch, north-central Montana: American Association of Petroleum Geologists Bulletin, v. 34, no. 9. p. 1899-1900.

1951a, Colorado shale of central and northwestern Montana and equivalent rocks of Black Hills: American Association of Petroleum Geologists Bulletin, v. 35, no. 10, p. 2170-2198.

1951b (1952), Scaphitoid cephalopods of the Colorado group: U.S. Geological Survey Professional Paper 239, 42 p., 21 pls.

- 1955a, Cretaceous rocks of northwestern Montana: Billings Geological Society Annual Field Conference, 6th, East Glacier, Mont.. 1955, Guidebook, p. 107-119.

1955b, Some guide fossils from the Colorado shale and Telegraph Creek formation, northwestern Montana: Billings Geological Society Annual Field Conference, 6th, East Glacier, Mont., 1955, Guidebook, p. 198-207, pls. 1-4.

1964, The Late Cretaceous cephalopod Haresiceras Reeside and its possible origin: U.S. Geological Survey Professional Paper 454-I, 21 p., 3 pls.

1969, The Late Cretaceous ammonites Scaphites leei Reeside and Scaphites hippocrepis (DeKay) in the Western 
Interior of the United States: U.S. Geological Survey Professional Paper 619, 29 p., 5 pls.

Cobban, W.A., and Reeside, J.B., Jr., 1952, Correlation of the Cretaceous formations of the Western Interior of the United States: Geological Society of America Bulletin, v. 63, no. 10, p. 1011-1043.

Cobban, W.A., Erdmann, C.E., Lemke, R.W., and Maughan, E.K.. 1976, Type sections and stratigraphy of the members of the Blackleaf and Marias River Formations (Cretaceous) of the Sweetgrass arch, Montana: U.S. Geological Survey Professional Paper 974, 66 p.

Collier, A.J., 1929 (1930), The Kevin-Sunburst oil field and other possibilities of oil and gas in the Sweetgrass arch, Montana: U.S. Geological Survey Bulletin 812-B, p. 57-189.

Ernst, G., 1963. Stratigraphische und gesteinschemische Untersuchungen im Santon und Campan von Lägerdorf (SWHolstein): Mitteilungen aus dem Geologischen Staatsinstitut in Hamburg, no. 32, p. 71-127.

1966, Fauna, Okologie und Stratigraphie der mittelsantonen Schreibkreide von Lägerdorf (SW-Holstein): Mitteilungen aus dem Geologischen Staatsinstitut in Hamburg, no. 35, p. $115-150$.

1973, Die Echiniden-Fauna des Santon der Gehrdener Berge: Bericht der Naturhistorischen Gesellschaft zu Hannover, v. 117, p. 79-102.

Ernst, G., and Schmid, F., 1975, Stand der geologischen Forschungsarbeiten in den Oberkreide-Mulden zwischen Misburg und Lehrte: Bericht der Naturhistorischen Gesellschaft zu Hannover, v. 119, p. 113-126.

Ernst, G., and Schulz, M.-G., 1974, Stratigraphie und Fauna des Coniac und Santon im Schreibkreide-Richtprofil von Lägerdorf (Holstein): Mitteilungen aus dem GeologischPaläontologischen Institut der Universität Hamburg, no. 43, p. 5-60.

Gill, T., 1871, Arrangement of the families of mollusks: Smithsonian Miscellaneous Collections 227, 49 p.

Keefer, W.R., and Troyer, M.L., 1956, Stratigraphy of the Upper Cretaceous and lower Tertiary rocks of the Shotgun Butte area, Fremont County, Wyoming,: U.S. Geological Survey Oil and Gas Investigations Chart OC-56, vertical scale $1: 3,000$.

1964, Geology of the Shotgun Butte area, Fremont County, Wyoming: U.S. Geological Survey Bulletin 1157. $123 \mathrm{p}$.

Klikushin, V.G., 1983, Distribution of crinoidal remains in the Upper Cretaceous of the U.S.S.R.: Cretaceous Research, v. 4, p. 101-106.
Knechtel, M.M. , and Patterson, S.H., 1956, Bentonite deposits in marine Cretaceous formations, Hardin district, Montana and Wyoming: U.S. Geological Survey Bulletin 1023, 116 p.

Lamarck, J.B.P.A. de M., de, 1799, Prodome d'un nouvelle classification des coquilles: Memoires de Société Historie Naturelle Paris, v. 1, p. 63-91. 1801, Système des animaux sans vertèbres: Paris, J.B.P.A. de M. de Lamarck, Chez Deterville, 432 p.

Meek, F.B., 1876, Invertebrate Cretaceous and Tertiary fossils of the upper Missouri country: U.S. Geological Survey of the Territories Report, v. 9, 629 p., 45 pls.

Mudge, M.R., 1972, Pre-Quaternary rocks in the Sun River Canyon area, northwestern Montana: U.S. Geological Survey Professional Paper 663-A, 142 p.

Reeside, J.B., Jr., 1927a, The cephalopods of the Eagle sandstone and related formations in the Western Interior of the United States: U.S. Geological Survey Professional Paper 151, 87 p., 45 pls.

-1927b, Cephalopods from the lower part of the Cody shale of Oregon Basin, Wyoming: U.S. Geological Survey Professional Paper 150-A, p. Al-A19, pls. 1-8.

Richards, P.W., 1955 (1956), Geology of the Bighorn CanyonHardin area, Montana and Wyoming: U.S. Geological Survey Bulletin 1026, 93 p.

Schmid, F., and Ernst, G., 1975, Ammoniten aus dem Campan der Lehrter Westmulde und ihre stratigraphische Bedeutung, I, Teil; Scaphites, Bostrychoceras und Hoplitoplacenticeras: Bericht der Naturhistorischen Gesellschaft zu Hannover, v. 119 , p. $315-359,4$ pls.

Scott, G.R., Cobban, W.A., and Merewether, E.A., 1986, Stratigraphy of the Upper Cretaceous Niobrara Formation in the Raton basin, New Mexico: New Mexico Bureau of Mines and Mineral Resources Bulletin 115, 34 p.

Smith, J.H., 1965, A summary of stratigraphy and paleontology, upper Colorado and Montanan Groups, south central Wyoming, northeastern Utah, and northwestern Colorado, in Sedimentation of Late Cretaceous and Tertiary outcrops, Rock Springs uplift: Wyoming Geological Association Field Conference, 19th, Rock Springs, Wyo., 1965, Guidebook, p. 13-26.

Thom, W.T., Jr., Hall, G.M., Wegemann, C.H., and Moulton, G.F., 1935, Geology of Big Horn County and the Crow Indian Reservation, Montana: U.S. Geological Survey Bulletin $856,200 \mathrm{p}$.

Yenne, K.A., and Pipiringos, G.N., 1954, Stratigraphic sections of Cody shale and younger Cretaceous and Paleocene rocks in the Wind River Basin, Fremont County, Wyoming: U.S. Geological Survey Oil and Gas Investigations Chart OC -49 , vertical scale $1: 3,600$. 


\section{PLATES 1, 2}

Contact photographs of the plates in this report are available, at cost, from the U.S. Geological Survey Photographic Library, Federal Center, Denver, CO 80225. 


\section{PLATE 1}

\section{Baculites thomi Reeside (p. C5)}

[All figures natural size]

Figures 1-21. From the upper part of the Kevin Member of the Marias River Shale at U.S. Geological Survey Mesozoic locality 21419, $12.9 \mathrm{~km}$ west of Shelby in the NE1/4 sec. 31, T. 32 N., R. 3 W., Toole County, Montana (fig. 1, loc. 8).

1-3. Hypotype USNM 440808.

4, 5. Hypotype USNM 440809.

6. Hypotype USNM 440810.

7, 8. Hypotype USNM 440811.

9, 10. Hypotype USNM 440812.

11, 12. Hypotype USNM 433906.

13-15. Hypotype USNM 433905.

16-18. Hypotype USNM 440813.

19-21. Hypotype USNM 433907. 

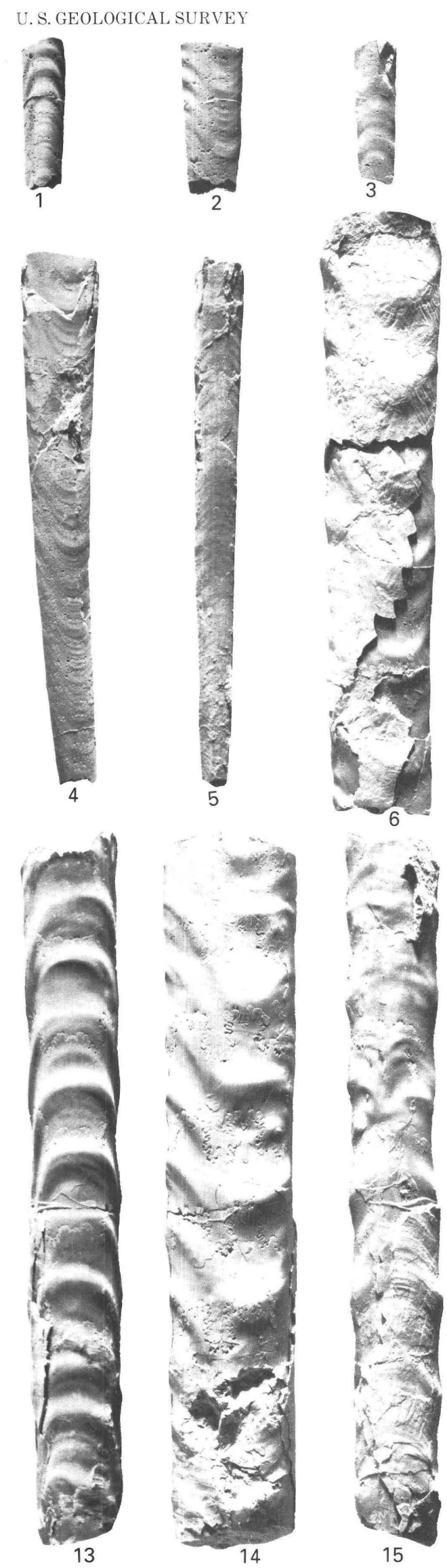
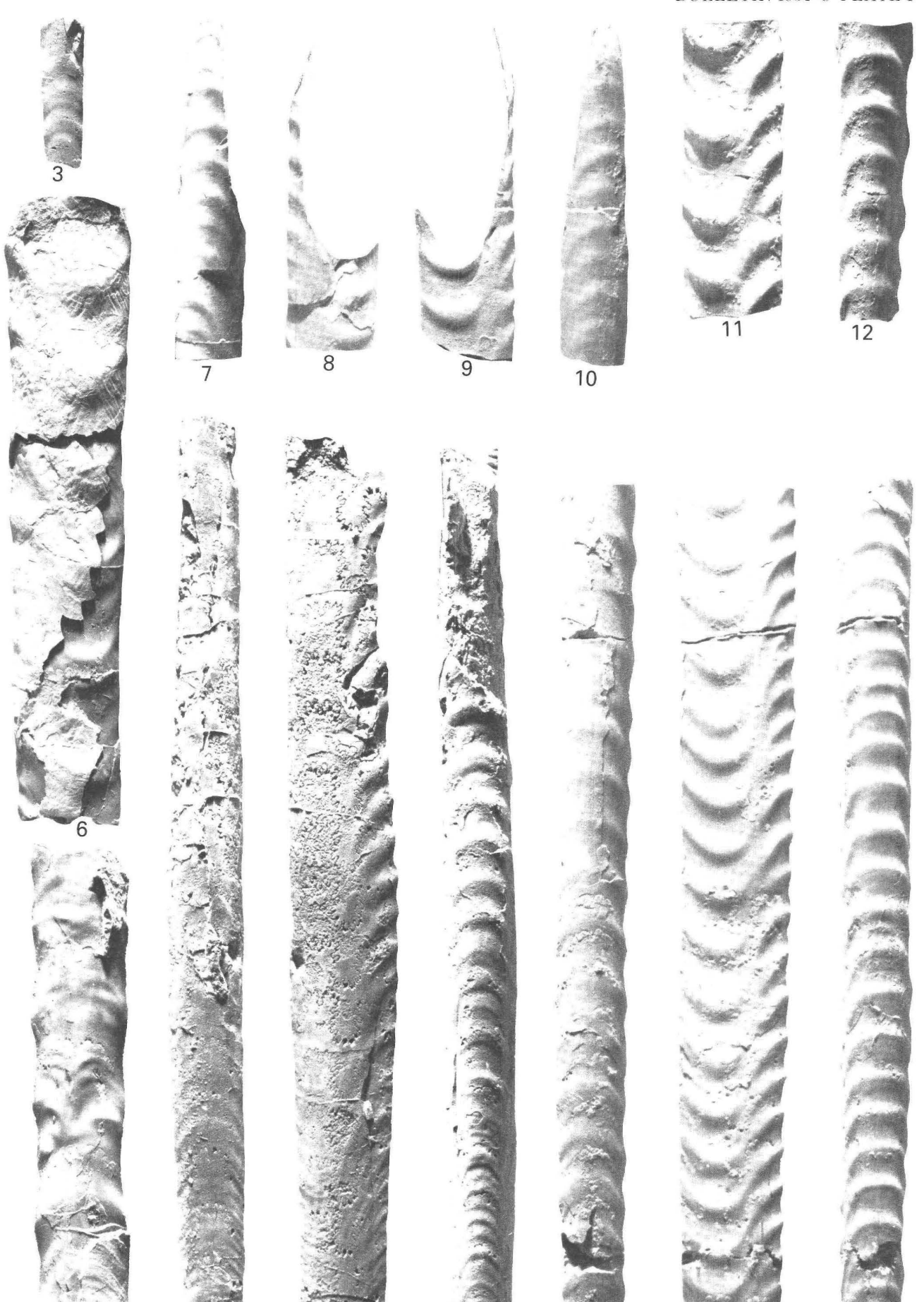

X.
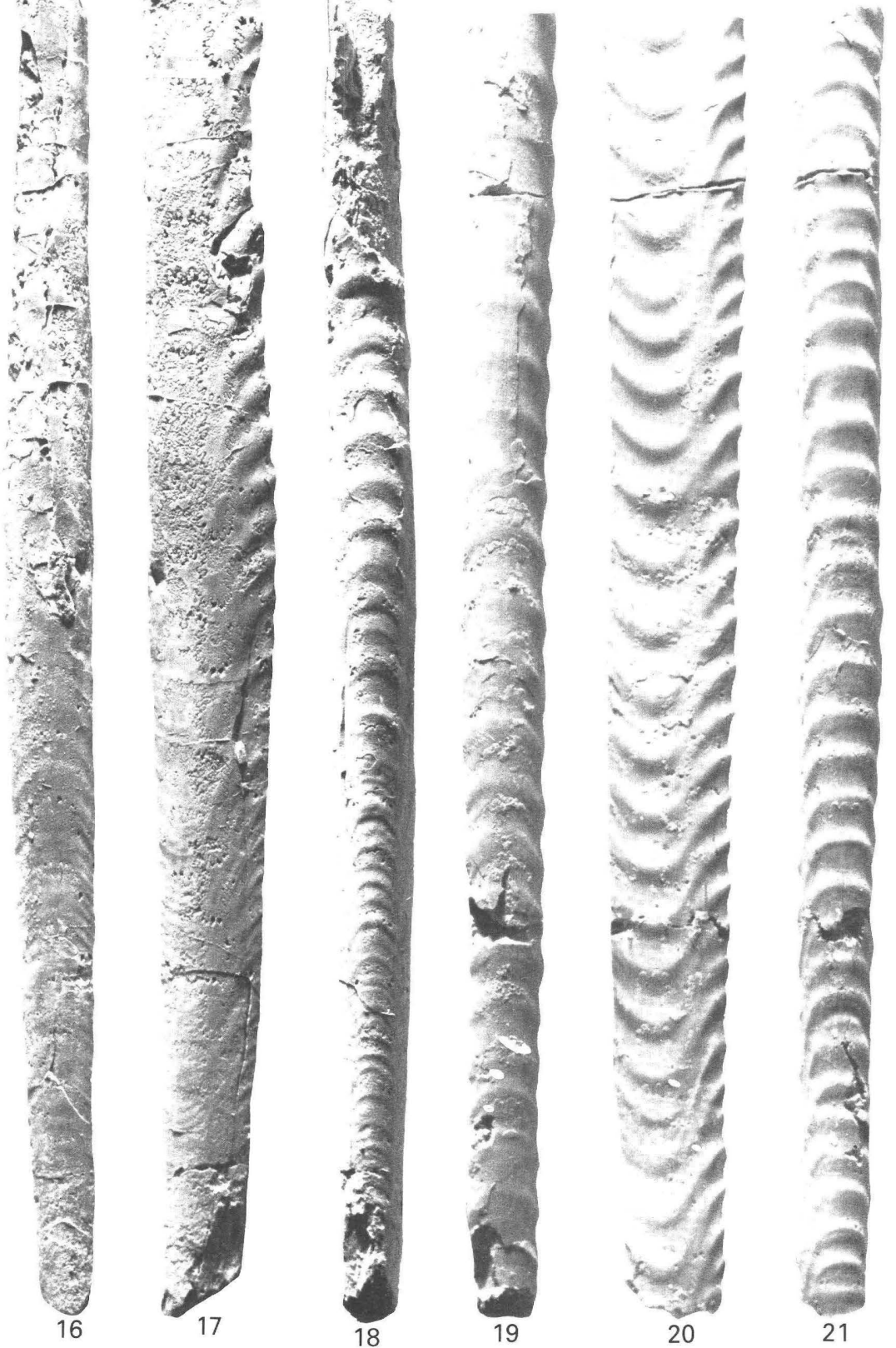


\section{PLATE 2}

\section{Baculites thomi Reeside (p. C5)}

[All figures natural size]

Figures 1-9. From the upper part of the Kevin Member of the Marias River Shale at U.S. Geological Survey Mesozoic locality 21419, $12.9 \mathrm{~km}$ west of Shelby in the NE1/4 sec. 31, T. 32 N., R. 3 W., Toole County, Montana (fig. 1, loc. 8).

1-3. Hypotype USNM 440814.

4-6. Hypotype USNM 440815.

7-9. Hypotype USNM 440816. 


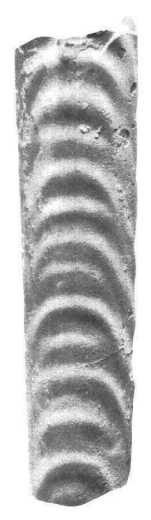

1

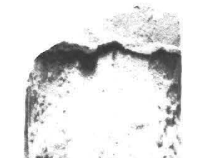

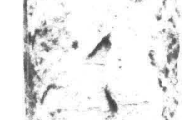

6
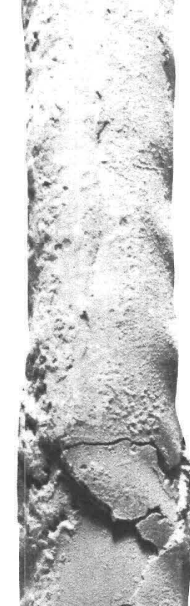

$4=5$

P.

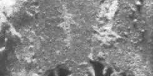

intent

f.

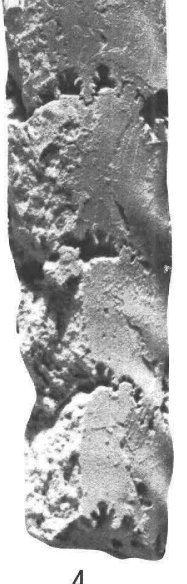

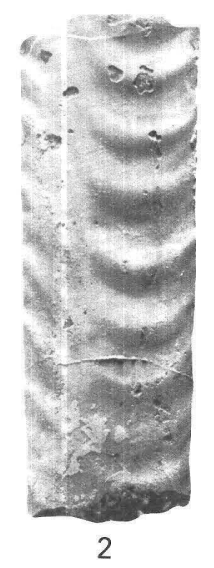

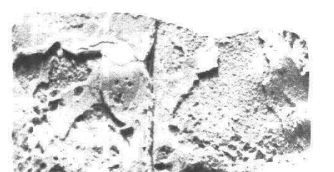

$6, \frac{2}{2-2}+2$
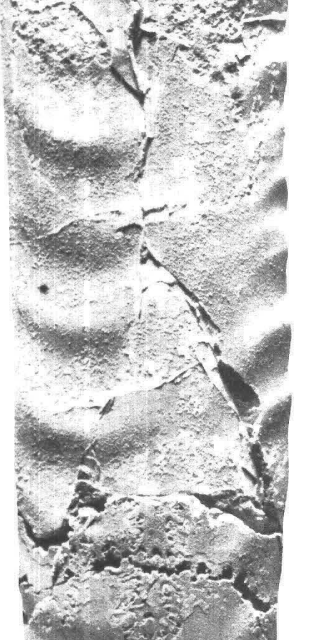

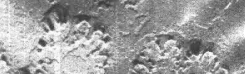
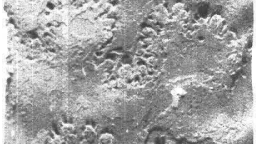

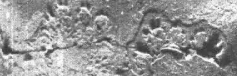

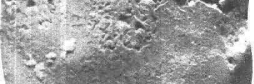

in: $3 x+1$

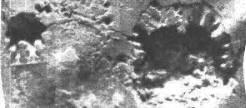

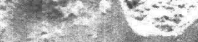

(x).

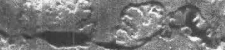

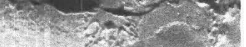

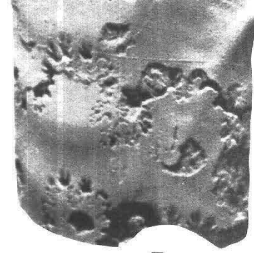

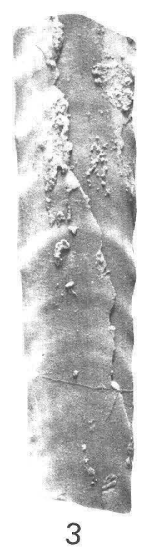
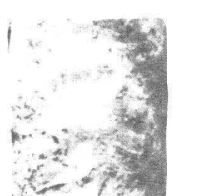

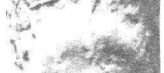

$1+\frac{x+3}{43}$
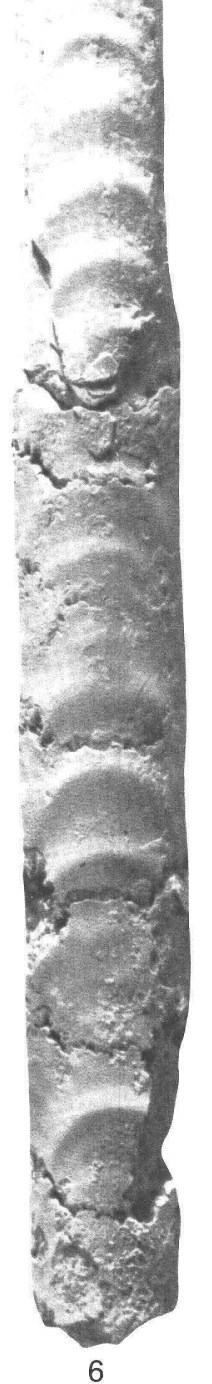

6
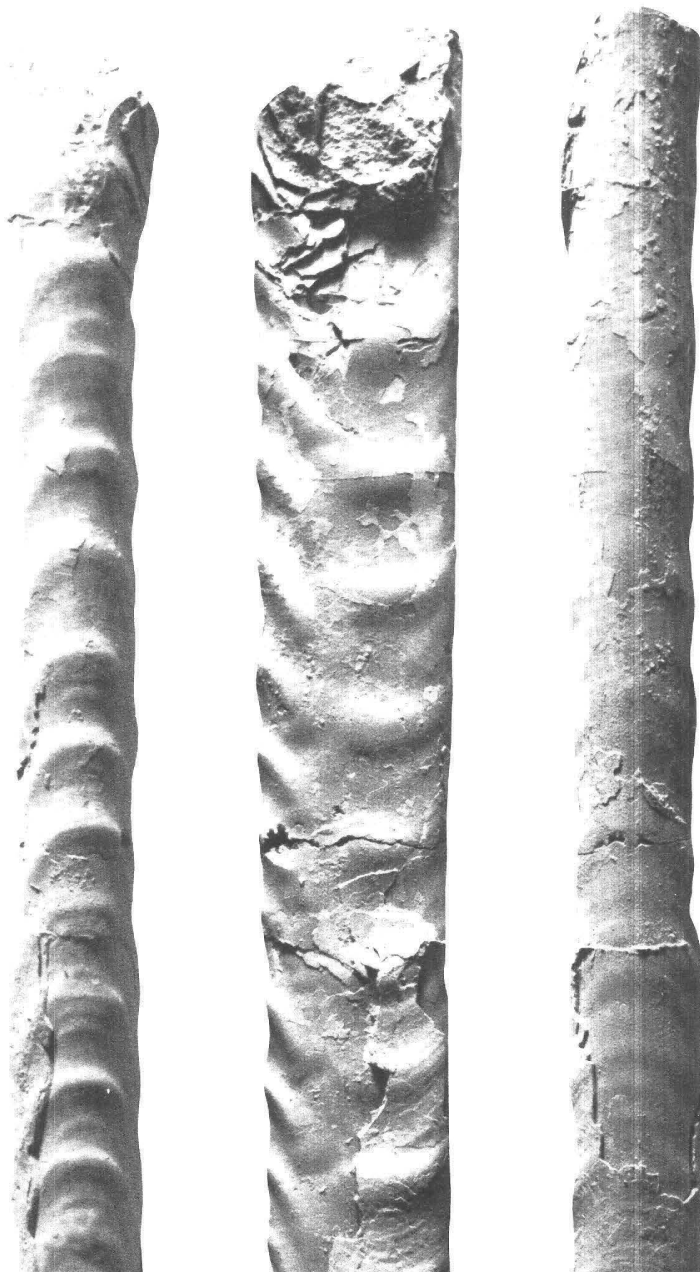

(- $(2:-3$

(3.

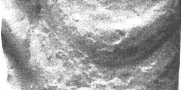

$1+2=8$

$1+28$

$x^{2}=-2$

4

$x^{2}+4$

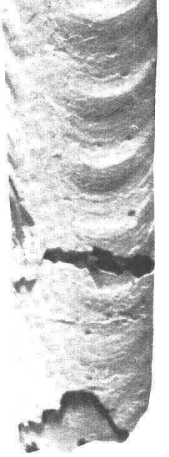

8

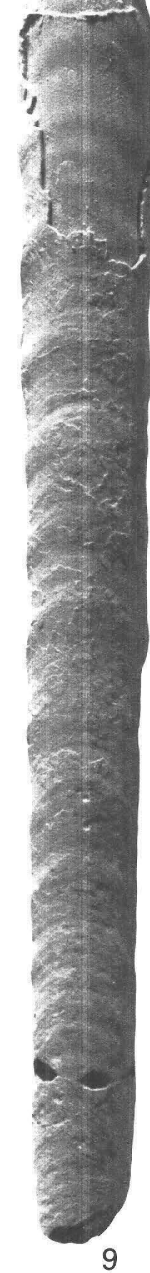

BACULITES THOMI 

Chapter D

\section{Discovery of Early Ordovician Fossils in Bucks County, Pennsylvania}

By JOHN E. REPETSKI and AVERY ALA DRAKE, JR.

U.S. GEOLOGICAL SURVEY BULLETIN 1934 


\title{
CONTENTS
}

\author{
Abstract D1 \\ Introduction D1 \\ Acknowledgments D1 \\ Previous Work D1 \\ Geology of the Buckingham Valley D2 \\ The Conodonts D4 \\ Conclusions D5 \\ References Cited D5

\section{PLATE} \\ [Plate follows references cited] \\ 1. Early Ordovician conodonts from Buckingham Valley, Bucks County, \\ Pennsylvania
}

\section{FIGURES}

1, 2. Maps showing:

1. Buckingham Valley, Pennsylvania D2

2. Geology of the Buckingham Valley, Bucks County, Pennsylvania, showing conodont localities D3 


\title{
Discovery of Early Ordovician Fossils in Bucks County, Pennsylvania
}

\author{
By John E. Repetski and Avery Ala Drake, Jr.
}

\begin{abstract}
Conodonts from dolomites in the Buckingham Valley carbonate rock sequence of Bucks County, Pennsylvania, are the first identifiable Early Ordovician fossils recovered from that area. They confirm previous lithostratigraphic correlation of those rocks with the Rickenbach Dolomite of the Beekmantown Group of the Great Valley sequence in eastern Pennsylvania and northern New Jersey. The fauna is assignable to the Lower Ordovician Rossodus manitouensis Zone, and the species and lithology indicate warm, shallow marine carbonate platform paleoenvironments.
\end{abstract}

\section{INTRODUCTION}

The current geologic map of Pennsylvania (Berg and others, 1980) shows an isolated area of Ordovician carbonate rocks in the Buckingham Valley of Bucks County. This sequence of poorly exposed dolomites historically has been identified as or correlated with lithologically similar Lower Ordovician units of the Beekmantown Group of the Great Valley sequence to the north and west. Previously, however, the age of these carbonate rocks had not been confirmed because no fossils had ever been reported from them. During our investigations of the stratigraphy and tectonic history of Lower Ordovician rocks in eastern Pennsylvania and northern New Jersey, we have sampled several outcrops of carbonate rocks in Bucks County (fig. 1). Conodonts recovered from some of these samples are the first Early Ordovician fossils reported from the Buckingham Valley and at last confirm the previous lithologic correlations of some of these rocks with the Rickenbach Dolomite of the Beekmantown Group.

\section{Acknowledgments}

We acknowledge and thank R.C. and A.L. Orndorff and D.J. Weary (U.S. Geological Survey) for their technical assistance in preparing the conodont samples and the illustrations for this project.

Manuscript approved for publication February 27, 1990.

\section{PREVIOUS WORK}

Rocks now called Beekmantown in eastern Pennsylvania were originally named Coplay by Wherry (1909), although he did no geologic mapping. Miller (1934) and Miller and others $(1939,1941)$ substituted the name Beekmantown for these rocks because they recognized their similarity to the Beekmantown of New York. Subsequently, most workers have used Beekmantown, although Willard (1958) pointed out, correctly, that the uppermost beds of the unit were of Chazyan (now late Whiterockian) age and that the name Coplay should be reinstated. The name Beekmantown, however, has become so entrenched that no workers have accepted Willard's suggestion. The Beekmantown was promoted to group status and divided into (in ascending order) the Stonehenge Limestone, the Rickenbach Dolomite, the Epler Formation (interbedded limestone and dolomite), and the Ontelaunee Formation (mostly dolomite) in eastern Pennsylvania (Hobson, 1957). Drake (1965) recognized two mappable units in the Delaware Valley that he correlated with Hobson's Rickenbach Dolomite and Epler Formation. More recently, Drake and Lyttle (1985) and Drake and others (1985) have recognized limestone near the base of the Beekmantown Group in New Jersey, and conodont studies by J.E. Repetski show that these rocks correlate with the Stonehenge Limestone of east-central Pennsylvania. These data led to a restudy of the Rickenbach Dolomite in the Delaware Valley, which showed that its lower part, although dolomite, can be mapped separately as Stonehenge Formation.

In the Buckingham Valley, the entire carbonate rock package was originally termed Auroral Limestone by Rogers (1858) and later Shenandoah Limestone (Bascom and others, 1909). G.W. Stose (in Bascom and others, 1931) was the first to suggest that some of the rocks were Beekmantown on the basis of their similarity to the Beekmantown Formation in the Lancaster Valley. Willard and others (1950) made the same correlation on the basis of the similarity to the Beekmantown Formation of the Lehigh Valley. Lyttle and Epstein (1987) recognized the similarity of the rocks earlier mapped as Beekmantown to the Rickenbach Dolomite as then mapped in eastern Pennsylvania 

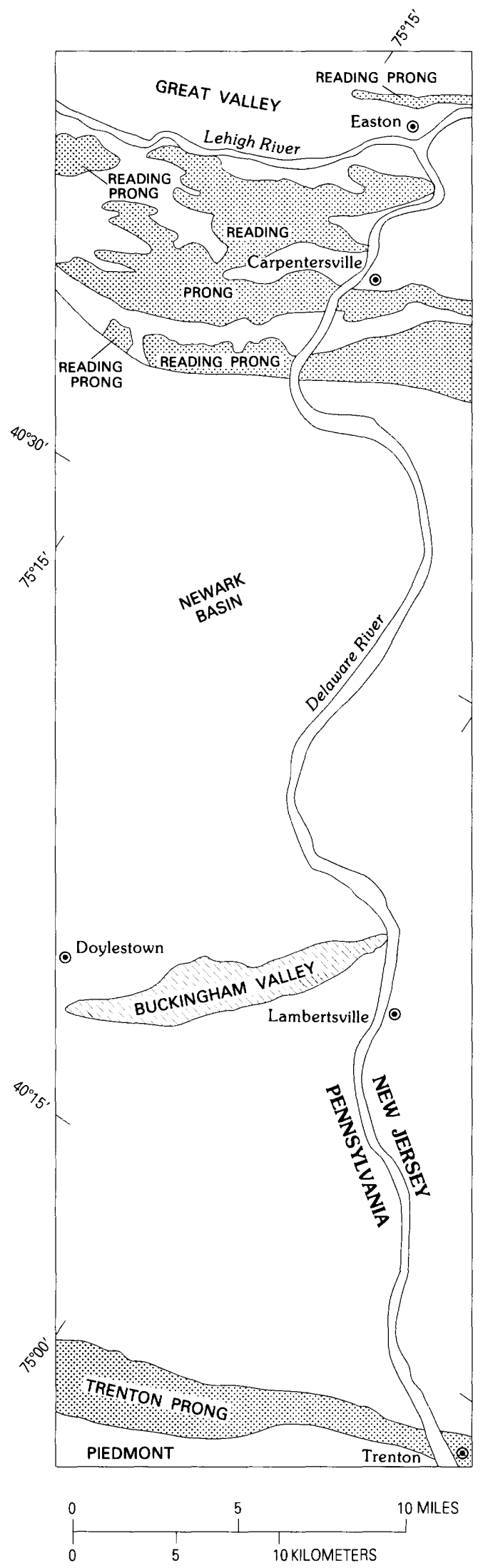

Figure 1. Buckingham Valley, Pennsylvania. Shading indicates crystalline rocks of the Reading Prong and the Trenton Prong. and New Jersey. The work reported on herein confirms the presence of the Rickenbach Dolomite in the Buckingham Valley.

\section{GEOLOGY OF THE BUCKINGHAM VALLEY}

The Buckingham Valley is an upthrown fault block within the Newark Mesozoic basin (fig. 2). It is important in that it exposes a part of the Laurentian shelf between the rocks of the Great Appalachian Valley to the north and the shelf-edge and slope deposits in the Piedmont to the south. Laurentian basement rocks may or may not crop out in Buckingham Mountain. Bascom and others (1931) showed a small area of gabbro on the southwestern crest of Buckingham Mountain, as did Gray and others (1960); Willard and others (1959) could find no outcrops and did not show crystalline rocks on their map (Willard and others, 1950). Berg and others (1980) showed a small area of gneiss where previous workers showed gabbro, whereas Lyttle and Epstein (1987) showed quartz diorite in this place. During our work, we found only a few pieces of nondescript crystalline rock float in a sandstone pit; therefore, we do not show Laurentian basement in figure 2 . That such basement is just below the surface is shown clearly on the aeromagnetic map of the Buckingham quadrangle (Bromery and others, 1959) by typical Reading Prong magnetic signatures. Buckingham and Little Buckingham Mountains are underlain by arkosic conglomerate, arkose, and orthoquartzite. Arkosic conglomerate occurs at the base of the unit and passes up into arkose and, finally, white orthoquartzite. Abundant conglomerate horizons suggest the presence of numerous intraformational unconformities. Olenellus fragments have been collected from the uppermost white quartzite beds. The rift-drift facies transition is difficult to pick but presumably is at the change from arkose to orthoquartzite. Only the highest beds, however, are proven to be marine. Bascom and others (1931) called these rocks Hardyston Quartzite, whereas Willard and others (1959) and Gray and others (1960) called them Chickies Quartzite. Berg and others (1980) and Lyttle and Epstein (1987) reverted to Hardyston Quartzite. Lithologically, the unit most closely resembles the Hardyston, the basal siliciclastic unit in the Reading Prong, although the $900-\mathrm{ft}$ thickness here is far greater than the $60 \mathrm{ft}$ measured in the Riegelsville quadrangle to the north (Drake, 1969). The Chickies Quartzite in the Trenton West quadrangle to the south consists of about equal parts of (1) white quartzite and a few pebble conglomerate beds and (2) quartz-muscovite schist (A.A. Drake, Jr., unpublished data, 1984). We think that the unit here best correlates with the Hardyston and that at least the upper part is of Early Cambrian age.

The Hardyston is overlain by a carbonate unit called the Elbrook Formation by Bascom and others (1931). This name seemed inappropriate to Howell and others (1950) and 


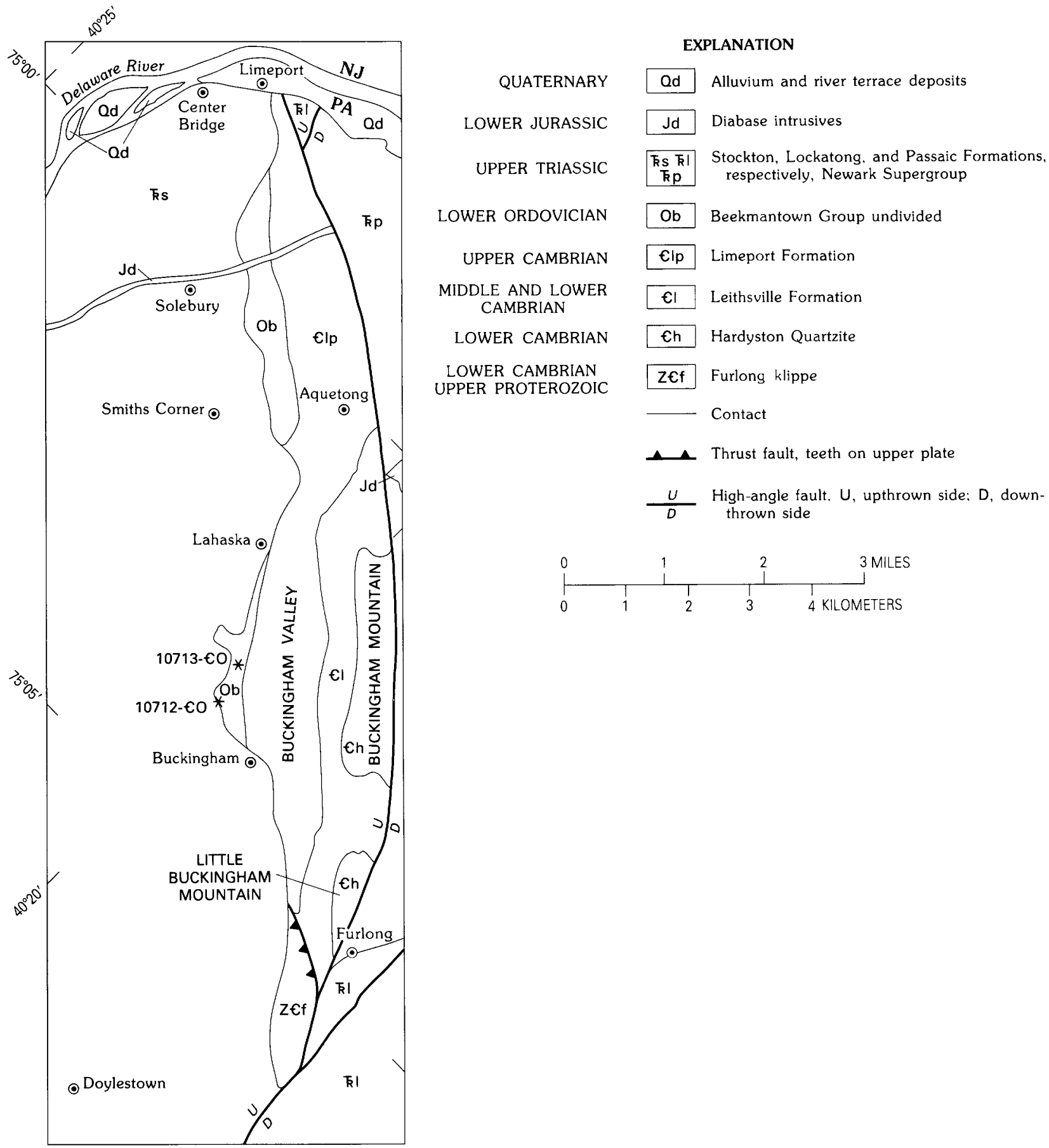

Figure 2. Geology of the Buckingham Valley, Bucks County, Pennsylvania (modified from Willard and others, 1950), showing conodont localities (10712-CO and 10713-CO).

Willard and others (1959) on the basis of both lithology and age - the Elbrook Formation is Middle and Late Cambrian. They therefore correlated this unit with the Leithsville Formation of the Lehigh Valley. This usage was followed by Berg and others (1980) and Lyttle and Epstein (1987). Our examination showed that the unit has all the features of the Leithsville of eastern Pennsylvania and New Jersey.
The Leithsville is succeeded upward by a cyclic, shallowing-upward sequence of flat-pebble dolomite, dololutite, dolarenite, oolitic dolarenite, dolorudite, algal stromatolite, and dolomicrite. This cycle was determined by direct observation in the field and was later confirmed by a Markov process study done by Aaron (1979). These rocks were mapped as Conococheague Limestone by Bascom and 
others (1931). Howell and others (1950) named the unit Limeport Limestone. This $400-$ to $500-\mathrm{ft}$ sequence is essentially identical to about the lower half of the Allentown Dolomite of the Great Valley to the north, and Howell and others (1950) separated the Allentown into a lower Limeport Limestone and an upper Allentown (restricted) Limestone. The typical Allentown cycles become less common in the upper Allentown, and intertidal deposits are sparse in higher beds.

The Limeport in the Buckingham Valley contains an early Late Cambrian (Dresbachian) fauna (Bascom and others, 1931; Howell, 1957), as do similar rocks in the lower Allentown at Carpentersville and Peapack, N.J., to the north (Howell, 1945). Late Cambrian (Trempealeauan) fossils were collected at Newton, Andover, and Blairstown, N.J., and Portland, Pa., in the Great Valley (Howell, 1945; Howell and others, 1950). These data led Howell and others (1950) to postulate an unconformity within the Allentown-their Limeport and Allentown Limestones-representing middle Late Cambrian (Franconian) time, as no fossils of that age have been found. No direct evidence for such an unconformity has been found in geologic mapping at a scale of 1:24,000 between the Schuylkill River in Pennsylvania and Orange County, New York. The lack of middle Late Cambrian fossils in these largely intertidal deposits is perhaps not surprising.

Berg and others (1980) and Lyttle and Epstein (1987) abandoned the name Limeport for the Upper Cambrian rocks in the Buckingham Valley and called them Allentown. We do not agree with this designation because (1) the Buckingham Valley is $20 \mathrm{mi}$ across strike from the Allentown outcrop belt, (2) the Limeport Formation is 400 to 500 $\mathrm{ft}$ thick as opposed to the $1,700 \mathrm{ft}$ of Allentown measured at Carpentersville, N.J. (Drake, 1969), and (3) the Limeport lacks the rocks typical of the upper half of the Allentown in the Great Valley. We therefore accept the name Limeport Formation for the Upper Cambrian rocks in the Buckingham Valley for use by the U.S. Geological Survey (USGS).

The lower part of the Beekmantown in the Buckingham Valley is very finely to finely crystalline, darkmedium- to medium-gray, earthy, laminated dolomite, like the dolomite mapped as Stonehenge Formation in New Jersey and eastern Pennsylvania. Higher beds, which constitute most of the Beekmantown in the area, consist of medium-gray to dark-medium-gray, fine- to mediumgrained, granular dolomite that appears to be massive. Weathered surfaces, however, show that most sedimentation units, marked by sandy lenses or partings, are of medium thickness. The dolomite contains abundant gray, somewhat translucent chert in lenses and partial beds as well as blocky to subrounded forms. Most exposures contain some solution collapse breccia. At some places, the solution collapse breccia is abundant. This rock is typical of the Rickenbach Dolomite as mapped in New Jersey and eastern Pennsylvania (Drake and Lyttle, 1985;
Drake and others, 1985; A.A. Drake, Jr., unpublished data, 1968-89). Paleontologic data reported herein support this correlation.

The physically highest rocks in the Buckingham Valley constitute the Furlong klippe (Drake and others, 1989), which lies across the contact between the Leithsville and the Limeport Formations at a high angle (fig. 2). These rocks were correlated with the Cocalico Shale of the Piedmont in Lancaster County, Pennsylvania, by Bascom and others (1931) and Willard and others (1950). The Cocalico Shale constitutes the Cocalico klippe of Drake and others (1989). The rocks of the Furlong klippe consist of green and purple variegated phyllite; purple phyllite; darkgray phyllite; light-green, siliceous, blocky phyllite; hard, coarse feldspathic sandstone; grayish-green quartzite; and polymictic quartzose conglomerate containing purple quartz clasts. These rocks resemble some of the older units of the Taconic klippe of New York and western New England (Drake and others, 1989). The hard green quartzite and polymict conglomerate closely resemble the Rensselaer Graywacke, whereas the other rocks resemble the Nassau Formation. The phyllites could equally be interbeds within the Rensselaer. If this correlation is correct, the Furlong klippe contains Iapetan rift-facies rocks of Late Proterozoic to Early Cambrian age, and the Buckingham Valley occurrence is the only one known south of the Rensselaer Plateau in New York.

\section{THE CONODONTS}

The conodonts found in the Buckingham Valley dolomites establish the age of these rocks as Early Ordovician. Although the faunules recovered are sparse, they contain index species that allow confident assignment to the Rossodus manitouensis Zone. The $R$. manitouensis Zone replaces North American Midcontinent Province conodont "Fauna C," the third of five sequential faunas recognizable in cratonic and shelf facies in North America (Ethington and Clark, 1971). The biozone consists of an association of species that range through the lower (but not basal) part of the Ibexian Series (sensu Ross and others, 1982). Work subsequent to 1971 (for example, Ethington and Clark, 1981; Landing, 1981; Repetski, 1982) has demonstrated that the ranges of some species of "Fauna C" extend into lower and (or) higher strata than the range of that faunal interval as originally defined, but this work generally has confirmed and clarified the biostratigraphic concept of "Fauna C." In addition, this subsequent work has shown that some of the species indeed are limited to the range of "Fauna C." Landing and others (1986) formally defined and named the $R$. manitouensis Zone, incorporating the recent data, and their concept is applied herein.

Two samples from the several scattered outcrops and small abandoned quarries near the village of Buckingham 
(locations shown in fig. 2) contained conodonts. A total of $5.5 \mathrm{~kg}$ of rock was processed for conodonts by means of standard techniques using formic acid and a 200-mesh bottom screen. One sample (USGS fossil locality 10712 $\mathrm{CO}$, fig. 2) (2 kg processed) produced a single specimen assignable only to Cordylodus cf. C. proavus Müller ( $\mathrm{pl}$. $1 O$ ) as well as one indeterminate coniform element. The other sample (USGS fossil locality 10713-CO, fig. 2) (3.5 $\mathrm{kg}$ processed) yielded the following:

1 Clavohamulus densus Furnish (pl. 1C)

2 C. spp.; possibly juvenile elements of $C$. densus (pl. 1D)

2 Juanognathus? n.sp. (pl. $1 L-N$ )

4 Loxodus bransoni Furnish (pl. 1A, B)

1 Rossodus manitouensis Repetski and Ethington (pl. 1H)

4 Scolopodus? sulcatus Furnish (pl. 1E-G)

6 Variabiloconus bassleri (Furnish) (pl. 1I-K)

2 indeterminate coniform elements

The color alteration index (CAI) of these conodont elements is $5 \frac{1}{2}$, which is consistent with the regional pattern in the Lower Ordovician of the Great Valley nearby (Karklins and Repetski, 1989).

The conodonts of the $R$. manitouensis Zone, including all of the diagnostic species found in the Buckingham Valley samples, are known from other Beekmantown Group exposures in the Great Valley, although most of these data are as yet unpublished in detail. Tipnis (1975) recovered species of the $R$. manitouensis Zone from the middle and upper parts of the Stonehenge Limestone near Reading in Berks County, Pennsylvania, and Repetski (1979; unpublished data, 1977) found that diagnostic $R$. manitouensis Zone species continue upward through the lower and middle parts of the overlying Rickenbach Dolomite in its type region, also in Berks County. This same stratigraphic range for the fauna-from approximately middle Stonehenge through middle Rickenbach-has been confirmed at numerous other localities and sections along strike in the Great Valley from the Reading vicinity eastward to the Delaware River and across northern New Jersey into Orange County, New York (J.E. Repetski and A.A. Drake, Jr., unpublished USGS collections, 1976-89; J.E. Repetski, cited by Ross and others, 1982; Savoy and others, 1981). Thus, the faunal data confirm the age equivalence and support the lithic correlation of the upper fossiliferous dolomites of the Buckingham Valley with the Rickenbach Dolomite in the Great Valley.

The presence of the species Clavohamulus densus and Loxodus bransoni, with or without Juanognathus? n.sp., indicates a warm, shallow marine environment having normal to slightly elevated salinity. The distribution of these species is consistently in rocks representing these types of environments. In the Eastern United States beyond the study region, this species association occurs in the shallow-water dolomites and limestones of the Great Mead- ows Formation (of Flower, 1964) in the Champlain Valley of New York (Repetski, 1977); in the middle to upper Stonehenge and lower Rockdale Run Formations in western Maryland (J.E. Repetski, USGS unpublished collections, 1976); in middle and upper Stonehenge Limestone in south-central Pennsylvania to western Virginia (Tipnis and Goodwin, 1972; Orndorff, 1988); and in middle to upper Chepultepec Dolomite in eastern Tennessee (Repetski, 1985). Both the conodont fauna and the lithology indicate that the Buckingham Valley carbonate sequence was part of this broad, shallow-water facies belt.

\section{CONCLUSIONS}

Our work shows that the rocks in the Buckingham Valley of Pennsylvania, previously inferred to belong to the Beekmantown Group, are Beekmantown. The carbonate sequence within the Buckingham Valley is similar to the shelf deposits of the Great Valley to the north; the transition to shelf edge and slope deposits lies farther south and is covered by rocks of the Newark Basin.

\section{REFERENCES CITED}

Aaron, J.M., 1979, A stochastic approach to definition of cyclicity in the Allentown Dolomite (Upper Cambrian), eastern Pennsylvania and northwestern New Jersey [abs.]: Geological Society of America Abstracts with Programs, v. 11, no. 1, p. 1 .

Bascom, F., Darton, N.H., Kummel, H.B., Clark, W.B., Miller, B.L., and Salisbury, R.D., 1909, Trenton [quadrangle], New Jersey-Pennsylvania, folio 167 of Geologic atlas of the United States: U.S. Geological Survey, 24 p., 3 maps.

Bascom, F., Wherry, E.T., Stose, G.W., and Jonas, A.I., 1931, Geology and mineral resources of the QuakertownDoylestown District, Pennsylvania and New Jersey: U.S. Geological Survey Bulletin 828, 62 p.

Berg, T.M., Edmunds, W.E., Geyer, A.R., and others, 1980. Geologic map of Pennsylvania: Harrisburg, Pennsylvania Geological Survey, 4th ser., scale 1:250,000.

Bromery, R.W., Henderson, J.R., Zandle, G.I., and others, 1959, Aeromagnetic map of the Buckingham quadrangle. Bucks County, Pennsylvania: U.S. Geological Survey Geophysical Investigations Map GP-215, scale 1:24,000.

Drake, A.A., Jr., 1965, Carbonate rocks of Cambrian and Ordovician age, Northampton and Bucks Counties, eastern Pennsylvania, and Warren and Hunterdon Counties, western New Jersey: U.S. Geological Survey Bulletin 1194-L, 7 p. 1969. Precambrian and lower Paleozoic geology of the Delaware Valley, New Jersey-Pennsylvania, in Subitzky, S.. ed., Geology of selected areas in New Jersey and eastern Pennsylvania and guidebook of excursions: New Brunswick, N.J., Rutgers University Press, p. 51-131.

Drake, A.A., Jr., and Lyttle, P.T., 1985, Geologic map of the Blairstown quadrangle, Warren County, New Jersey: U.S. Geological Survey Geologic Quadrangle Map GQ-1585, scale $1: 24,000$. 
Drake, A.A., Jr., Kastelic, R.L., Jr., and Lyttle, P.T., 1985, Geologic map of the eastern parts of the Belvidere and Portland quadrangles, Warren County, New Jersey: U.S. Geological Survey Miscellaneous Investigations Map I-1530, scale 1:24,000.

Drake, A.A., Jr., Sinha, A.K., Laird, J., and Guy, R., 1989, The Taconic orogen, in Hatcher, R.D., Thomas, W.A., and Viele, G.W., eds., The Appalachian-Ouachita orogen, in The geology of North America: Boulder, Colo., Geological Society of America, v. F-2, p. 101-177.

Ethington, R.L., and Clark, D.L., 1971, Lower Ordovician conodonts in North America, in Sweet, W.C., and Bergström, S.M., eds., Symposium on conodont biostratigraphy: Geological Society of America Memoir 127, p. 63-82.

1981, Lower and Middle Ordovician conodonts from the Ibex area, western Millard County, Utah: Brigham Young University Geology Studies, v. 28, no. 2, 155 p.

Flower, R.H., 1964, The nautiloid Order Ellesmeroceratida (Cephalopoda): New Mexico Bureau of Mines and Mineral Resources Memoir 12, 234 p.

Gray, C., and others, 1960, Geologic map of Pennsylvania: Harrisburg, Pennsylvania Geological Survey, 4th ser., scale 1:250,000 (with sections).

Hobson, J.P., 1957, Lower Ordovician (Beekmantown) succession in Berks County, Pennsylvania: American Association of Petroleum Geologists Bulletin, v. 41, p. 2710-2722.

Howell, B.F., 1945, Revision of the Upper Cambrian faunas of New Jersey: Geological Society of America Memoir 12, $46 \mathrm{p}$.

1957, Upper Cambrian fossils from Bucks County, Pennsylvania: Pennsylvania Geological Survey Bulletin G28, $39 \mathrm{p}$.

Howell, B.F., Roberts, H., and Willard, B., 1950, Subdivision and dating of the Cambrian of eastern Pennsylvania: Geological Society of America Bulletin, v. 61, p. 1355-1368.

Karklins, O.L., and Repetski, J.E., 1989, Distribution of selected Ordovician conodont faunas in northern New Jersey: U.S. Geological Survey Miscellaneous Field Studies Map MF-2066, scale 1:185,000.

Landing, E., 1981, Conodont biostratigraphy and thermal color alteration indices of the upper St. Charles and lower Garden City formations, Bear River Range, northern Utah and southeastern Idaho: Evidence for a diachronous disconformity in the Lower Ordovician: U.S. Geological Survey Open-File Report 81-740, 22 p.

Landing, E., Barnes, C.R., and Stevens, R.K., 1986, Tempo of earliest Ordovician graptolite faunal succession: Conodontbased correlations from the Tremadocian of Quebec: Canadian Journal of Earth Science, v. 23, p. 1928-1949.

Lyttle, P.T., and Epstein, J.B., 1987, Geologic map of the Newark $1^{\circ} \times 2^{\circ}$ quadrangle, New Jersey, Pennsylvania, and New York: U.S. Geological Survey Miscellaneous Investigations Map I-1715, scale 1:250,000.

Miller, B.L., 1934, Limestones of Pennsylvania: Pennsylvania Geological Survey Bulletin M20, 4th ser., 729 p.
Miller, B.L., and others, 1939, Northampton County, Pennsylvania: Pennsylvania Geological Survey Bulletin C48, 4th ser., $496 \mathrm{p}$.

1941, Lehigh County, Pennsylvania: Pennsylvania Geological Survey Bulletin C39, 4th ser., 492 p.

Orndorff, R.C., 1988, Latest Cambrian and earliest Ordovician conodonts from the Conococheague and Stonehenge Limestones of northwestern Virginia: U.S. Geological Survey Bulletin 1837-A, p. A1-A18.

Repetski, J.E., 1977, Conodont-based correlation of the Lower Ordovician sequence near Ft. Ann, New York [abs.]: International Symposium on the Ordovician System, 3d, Columbus, Ohio, 1977, Program and Abstracts, p. 34.

1979. Paleontological studies of the Ordovician in Pennsylvania [abs.]: Geological Society of America Abstracts with Programs, v. 11, no. 1, p. 50.

1982. Conodonts from El Paso Group (Lower Ordovician) of westernmost Texas and southern New Mexico: New Mexico Bureau of Mines and Mineral Resources Memoir 40, $121 \mathrm{p}$.

1985, Biostratigraphy of the Knox Group at the Thorn Hill and River Ridge sections, northeastern Tennessee, in Walker, K.R., ed., The geologic history of the Thorn Hill Paleozoic section (Cambrian-Mississippian), eastern Tennessee: University of Tennessee Studies in Geology 10, p. 25-31.

Rogers, H.D., 1858, The geology of Pennsylvania, a government survey: Philadelphia, Pa., 2 v., 1,045 p.

Ross, R.J., Jr., and 27 others, 1982, The Ordovician System in the United States: International Union of Geological Sciences Publication 12, $73 \mathrm{p}$.

Savoy, L., Harris, A.G., and Repetski, J.E., 1981, Paleogeographic implications of the Lower/Middle Ordovician boundary, northern Great Valley, eastern Pennsylvania to southeastern New York [abs.]: Geological Society of America Abstracts with Programs (Northeastern Section), v. 13, no. 3, p. 174.

Tipnis, R.S., 1975, Conodont biostratigraphy of the Stonehenge Formation: Philadelphia, Pa., Temple University, unpublished M.A. thesis, $128 \mathrm{p}$.

Tipnis, R.S., and Goodwin, P.W., 1972, Lower Ordovician conodonts from the Stonehenge Formation of Pennsylvania and Maryland [abs.]: Geological Society of America Abstracts with Programs, v. 4, no. 5, p. 352.

Wherry, E.T., 1909, The early Paleozoic of the Lehigh Valley district, Pennsylvania: Science (new series), v. 30, p. 416.

Willard, B., 1958, Lower Ordovician, Lehigh and Delaware Valleys: Proceedings of the Pennsylvania Academy of Science, v. 32, p. 177-183.

Willard, B., McLaughlin, D.B., Watson, E.H., and others, 1950 , Geologic map of Bucks County, Pennsylvania: Harrisburg, Pennsylvania Geological Survey, scale 1:62,500.

Willard, B., and others, 1959, Geology and mineral resources of Bucks County, Pennsylvania: Pennsylvania Geological Survey Bulletin C9, 4th ser., 243 p. 


\section{PLATE 1}

Contact photographs of the plate in this report are available, at cost, from the

U.S. Geological Survey Photographic Library, Federal Center, Denver, CO 80225. 


\section{PLATE 1}

\section{Early Ordovician conodonts from the Buckingham Valley, Bucks County, Pennsylvania}

[All specimens are from USGS fossil locality 10713-CO, except $O$, which is from USGS fossil locality 10712-CO. Specimens are coated only with carbon for scanning electron microscope photography and are reposited in the type collections of the Paleobiology Department, U.S. National Museum of Natural History, Washington, DC 20560.]

A, B. Loxodus bransoni Furnish. Inner lateral views of posterior portions of two specimens: USNM $442680(\times 100)$ and USNM 442681 $(\times 240)$.

C. Clavohamulus densus Furnish. Posterior view; USNM $442682(\times 165)$.

D. Clavohamulus sp. Basal posterior view of small specimen, possibly a juvenile of $C$. densus; USNM $442683(\times 225)$.

$E-G$. Scolopodus? sulcatus Furnish. Posterolateral views of asymmetrical specimens $(E, F)$, USNM $442684(\times 175)$ and USNM $442685(\times 95)$; posterior view of broken symmetrical element $(G)$, USNM $442686(\times 135)$.

H. Rossodus manitouensis Repetski and Ethington. Posterolateral view of coniform element, USNM $442687(\times 225)$.

$I-K$. Variabiloconus bassleri (Furnish). Outer $(I)$ and inner $(J, K)$ lateral views: USNM $442688(\times 190)$, USNM $442689(\times 180)$, and USNM $442690(\times 225)$.

$L-N$. Juanognathus? n.sp. Upper oblique $(L)$ and posterolateral $(M, N)$ views of three specimens: USNM $442691(\times 250)$, USNM $442692(\times 180)$, and USNM $442693(\times 180)$.

O. Cordylodus cf. C. proavus Müller. Posterolateral view of inner side of juvenile or primitive cordylodan morphotype; USNM 442694 ( $\times 355)$. 


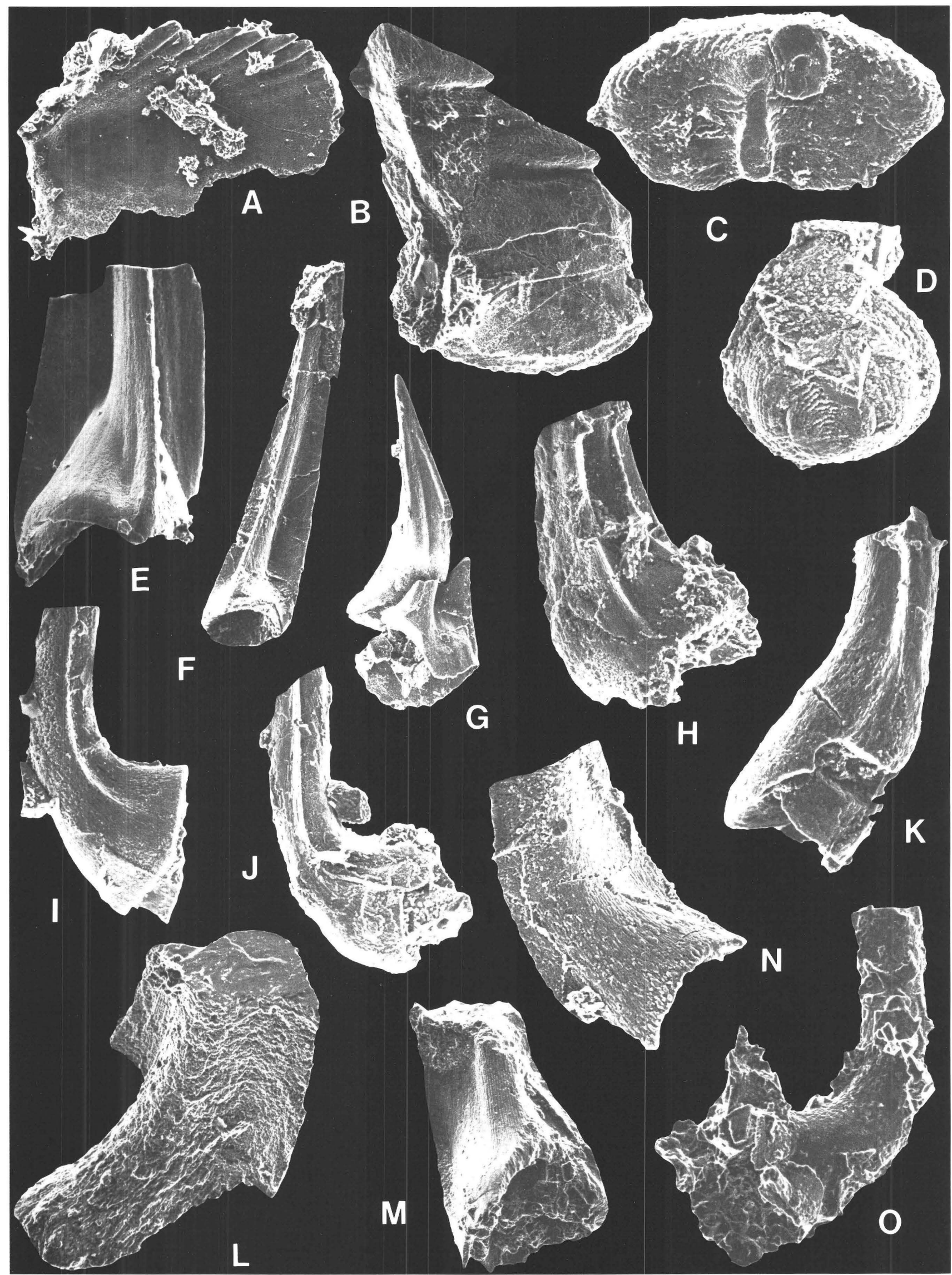

EARLY ORDOVICIAN CONODONTS FROM BUCKS COUNTY, PENNSYLVANIA 

Chapter E

An Unusual Late Cretaceous Fauna from an Oyster-Rich Interval in the Santa Cruz Mountains of California

By WILLIAM P. ELDER

U.S. GEOLOGICAL SURVEY BULLETIN 1934

SHORTER CONTRIBUTIONS TO PALEONTOLOGY AND STRATIGRAPHY 



\title{
CONTENTS
}

\author{
Abstract E1 \\ Introduction E1 \\ Acknowledgments E1 \\ Stratigraphic and Geologic Setting E2 \\ Depositional Setting E2 \\ Age and Correlation E4 \\ Characteristic Molluscan Fossils E8 \\ Barbatia sp. $\quad$ E8 \\ Mytilus sp. cf. M. quadratus Gabb, 1869 E8 \\ Isognomon sp. E9 \\ Inoceramus (Endocostea?) sp. aff. I. (E.?) cymbaeformis Pergament, 1974 E9 \\ Lyriochlamys traskii (Gabb), 1864 E10 \\ Spondylus subnodosus (Packard), 1922 E10 \\ Acesta n.sp. A E10 \\ Lima n.sp. A E11 \\ Amphidonte (Amphidonte) parasitica (Gabb), $1864 \quad \mathbf{E 1 1}$ \\ Crassatella spp. E11 \\ Other Faunal Components $\mathbf{E 1 2}$ \\ Paleoecologic and Paleobiogeographic Conclusions E13 \\ References Cited E13 \\ Appendix. - Locality Information for Fossil Localities Mentioned in Text and \\ Table $1 \quad \mathbf{E 1 7}$
}

\section{PLATES}

[Plates follow references cited]

1-3. Late Cretaceous mollusks

4. Late Cretaceous invertebrates

5. Late Cretaceous coral and ichnofossils

\section{FIGURES}

1. Map showing the locations and settings of rocks similar to the Great Valley sequence near Loma Prieta, Calif. E3

2. Drawing of stratigraphic column of the oyster-rich zone at locality M8525 E4

3-5. Photographs showing:

3. Cross-sectional view typical of the oyster-rich interval $\mathbf{E 4}$

4. Print made from an acetate peel of the oyster coquinite showing the fabric of the bed E5

5. Pebbly to cobbly conglomeratic zone in the shell-bed interval E5 


\section{TABLES}

1. Checklist of macrofossils from the upper Campanian to lower Maastrichtian rocks near Loma Prieta, Calif. E6

2. Geographic distribution of some selected taxa in the oyster beds near Loma Prieta, Calif. E9 


\title{
An Unusual Late Cretaceous Fauna from an Oyster-Rich Interval in the Santa Cruz Mountains of California
}

\author{
By William P. Elder
}

\begin{abstract}
Deformed fossiliferous strata resembling the Great Valley sequence are present in a fault wedge near Loma Prieta in the Santa Cruz Mountains of California. Macrofaunal analysis of these strata indicates a late Campanian to early Maastrichtian age for the upper part of this sequence. Numerous unusual species are present in this interval of turbidite deposits, the least common of which are found near the base of the Upper Cretaceous strata in a zone containing abundant Amphidonte exogyrid oysters and Calcispongea. Among the fossils discussed and illustrated from this zone in this paper, the following are either extremely rare or previously unreported in strata of this age in California: the bivalves Isognomon sp., Barbatia sp., Acesta n.sp., Lima n.sp., and Inoceramus (Endocostea?) sp. aff. I. (E.?) cymbaeformis Pergament; an Astrangiidae? coral species; and a species of Calcispongea. In addition to the unusual macrofossils present in this interval, dissolution of shell material in some beds has produced exquisite casts of shell borings, which also are briefly discussed and illustrated.

Composition of the oyster-rich assemblage indicates a relatively high energy, near-shore habitat consisting of mixed sand and rock or shell-bed substrates. These sediments were subsequently transported downslope by turbidity currents. Fossils found in the overlying Upper Cretaceous strata are indicative of a more offshore shelf habitat, which suggests a seaward shift in sediment source area or transgression through time. Component taxa in the oyster beds include North Pacific species whose tectonically transported distributions range from Baja California to Vancouver Island, British Columbia. Some of these species have been previously reported only to the north and some only to the south of Loma Prieta. Thus, the unusual faunal composition of the oyster beds appears to be caused by the preservation of a very near shore assemblage, which is rare in strata of this age in California, rather than by biogeographic constraints. The apparent absence of rudists in this very near shore assemblage, where they would be expected if present, suggests signif-
\end{abstract}

Manuscript approved for publication February 27, 1990. icant displacement of the Upper Cretaceous rudistbearing rocks west of the San Andreas fault relative to those near Loma Prieta.

\section{INTRODUCTION}

Upper Cretaceous rocks east of the San Andreas fault in California's Santa Cruz Mountains have been poorly dated, and the macrofossils have received little study. Yet important clues about post-Late Cretaceous displacement along fault systems to the east of and on the San Andreas fault in the San Francisco Bay area are provided by this isolated patch of moderately fossiliferous, deformed rocks that are structurally and lithologically similar to portions of the Great Valley sequence. Although determination of the relationship between these rocks and age-equivalent rocks deposited in the Central Valley of California and to the south is still in the formative stage, an important step to understanding the degree and history of displacement along the California margin is the documentation of complete macrofossil assemblages present during different time slices. This paper documents some late Campanian to early Maastrichtian fossil assemblages present near Loma Prieta in the Santa Cruz Mountains and discusses in particular an unusual assemblage of turbidite transported near-shore fossils associated with an oyster coquinite.

Many of the fossils found in and adjacent to this oyster- rich interval are rare taxa that are poorly illustrated in the literature or have not been previously known or described. Thus, in addition to documenting the age and composition of these assemblages, the fossils and molds associated with the oyster-rich zone, although typically poorly preserved, offer the opportunity to illustrate several of these rare and undescribed taxa. Also, zones of complete shell dissolution have yielded exquisite casts of shell borings, which will be illustrated and briefly discussed.

\section{Acknowledgments}

I wish to thank Alan H. Cheetham and Thomas R. Waller (U.S. National Museum of Natural History), J. 
Keith Rigby (Brigham Young University), and LouElla R. Saul (Natural History Museum of Los Angeles County) for their discussion and assistance on the identification of bryozoans, pectens, sponges, and bivalves, respectively. Robert J. McLaughlin and William V. Sliter (U.S. Geological Survey) are acknowledged for their assistance in the field, for their discussions, and for their review of this paper. I also am grateful to John W. Miller (U.S. Geological Survey) for his help in the field and the laboratory and to Louie Marincovich, Jr. (U.S. Geological Survey) and David L. Jones (University of California at Berkeley) for reviewing the manuscript.

\section{STRATIGRAPHIC AND GEOLOGIC SETTING}

The fossils reported on in this study come from an unnamed fault-bounded stratigraphic unit that has been informally referred to as Upper Cretaceous "sedimentary rocks in the Sierra Azul" by Bailey and Everhart (1964) and Upper Cretaceous "sandstone, shale, and conglomerate of Sierra Azul" by McLaughlin and others (1988a). Faults at low angles to bedding (interpreted as normal detachment faults) apparently separate the Upper Cretaceous rocks from the underlying Upper Jurassic to Lower Cretaceous and the overlying Eocene strata (McLaughlin and others, 1988a). The Upper Cretaceous unit lies in an extremely folded and faulted region, but its outcrop belt forms a roughly elongate wedge truncated by numerous faults-namely, the San Andreas, Lomita, and Sargent fault zones to the southwest and the Hooker, Soda Springs, and Berrocal faults to the northeast (text fig. 1) (Dibblee and Brabb, 1978; McLaughlin and others, 1988a). Some of these faults are presently active (San Andreas, Lomita, Sargent) or are suspected to be active (Berrocal).

The amount of post-Late Cretaceous displacement of this Upper Cretaceous fault wedge is unknown. Faunal assemblages and lithostratigraphic distributions in these rocks and in those of similar age to the east along the margins of the Diablo Range are too poorly understood at present to form any conclusive correlations.

The Upper Cretaceous rocks of the Sierra Azul consist of a basal conglomeratic unit containing pebble to boulder clasts, primarily of volcanic and plutonic rock types (Simoni, 1974; McLaughlin and others, 1988a). This conglomerate forms an areally extensive, massive bed up to approximately $1,000 \mathrm{~m}$ thick in the northern part of the outcrop belt but is present as thinner lenses in some areas, particularly in the southern part of its distribution (McLaughlin and others, 1988a; R.J. McLaughlin, oral commun., 1989). The interval of oyster beds discussed in this paper is associated with the uppermost part of this conglomeratic interval and is found in a zone of interbedded fine- to medium-grained lithic wacke, pebble to cobble conglomerate, oyster-rich coquinite, and vuggy wacke resulting from the dissolution of bioclasts (text fig. 2). McLaughlin and others (1988a) have interpreted this basal conglomeratic unit to be bounded by low-angle normal faults at most places, although it is locally depositionally overlain by sandstone and argillite.

Overlying the conglomeratic unit are strata primarily composed of rhythmically interbedded sandstone and argillite exhibiting thinning-upward bedding cycles, load features, plane laminations at tops of beds and, rarely, graded bedding; conglomeratic lenses are locally present (McLaughlin and others, 1988a). No fossils have been found in this flyschlike unit, the thickness of which is difficult to ascertain because of structural complications. The upper part of the Upper Cretaceous section is largely massive, sandy to silty argillite and wacke containing some fossiliferous carbonate concretions. The uppermost part of this argillaceous interval contains an upward-thickening sequence of sandstone and shale beds. No fossils have been found in the uppermost part of the unit, which is interpreted as being in fault contact with an overlying conglomeratic unit of early Eocene age (McLaughlin and others, 1988a). The entire Upper Cretaceous sequence probably consists of 400 to $1,100 \mathrm{~m}$ of section, depending on location and possible complications caused by faulting.

\section{DEPOSITIONAL SETTING}

The lithologies and bed forms in the Upper Cretaceous rocks of the Sierra Azul are indicative of a deep-sea fan deposit (for example, Normark, 1978; Walker, 1978, 1984: Nilsen, 1980). Deep-sea fan deposits are widely developed in strata of equivalent age in the San Joaquin Valley of California (Ingersoll, 1979), as well as in southern California and northern Baja California (Bottjer and Link, 1984). As noted earlier, the overall facies pattern in the Sierra Azul rocks is from unsorted and poorly sorted conglomerate, to finely interbedded sandstone and shale displaying upward-thinning sequences, to massive sandstone and argillite, and finally to an upward-thickening sequence of interbedded sandstone and shale. This pattern suggests transition from an inner to midfan channel setting at the base of the sequence (massive conglomerate), to a distal midfan or possibly back-levee environment (flyschlike deposits) in the middle part of the sequence, and, finally, to a midfan channel progradational setting (massive to interbedded argillite and wacke) near the top of the section (compare with Walker, 1978; Ingersoll, 1978).

The oyster coquina beds were apparently deposited near the time that the basal conglomerate-filled channel began to be filled in with finer grained sediments. Bedding in this oyster-rich interval suggests two upward-thinning sequences (text fig. 2). Exposures of the oyster beds are poor and widely spaced, but the beds have been traced intermittently for over $6 \mathrm{~km}$ along strike (text fig. 1, locs. 


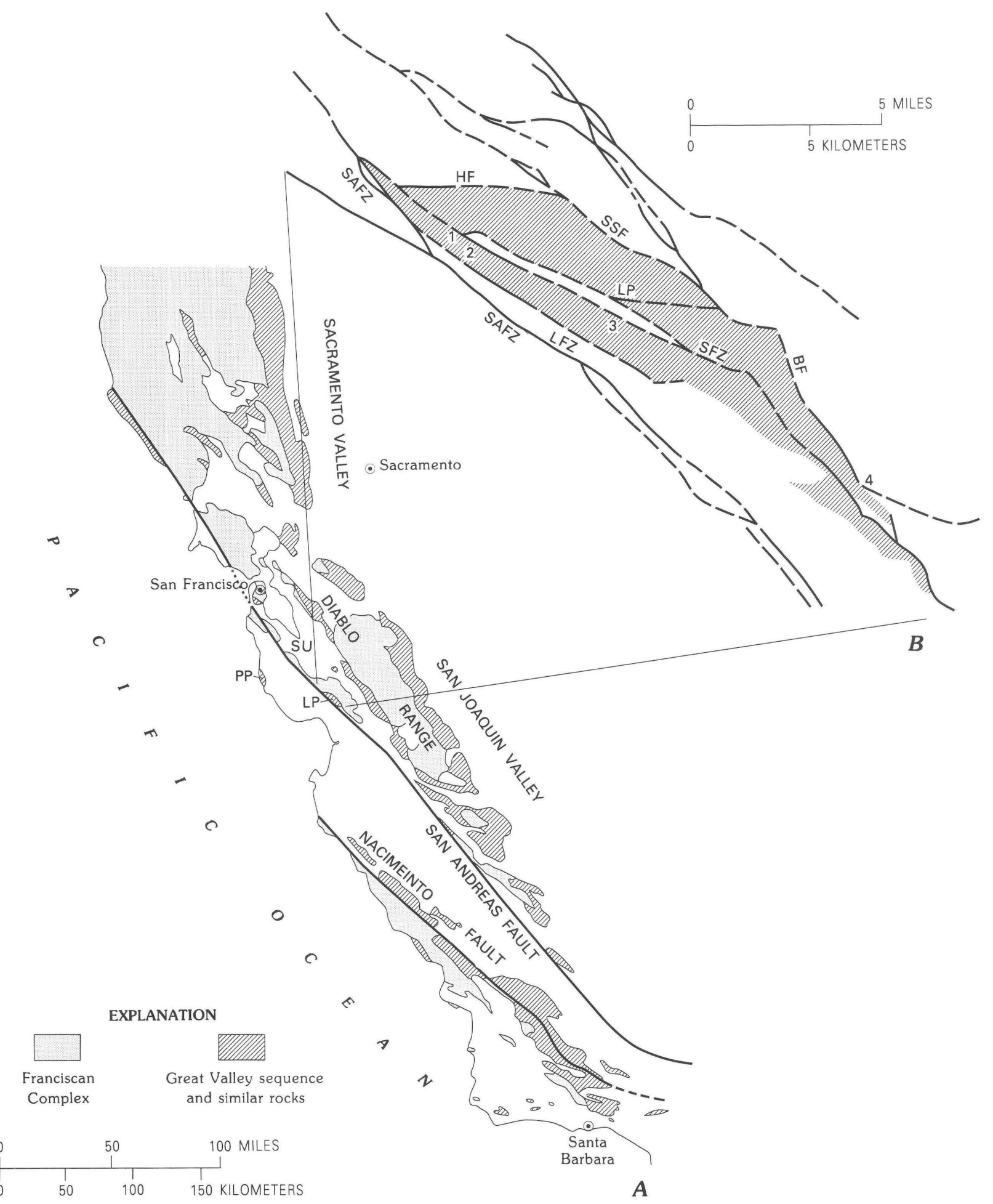

Figure 1. Locations and settings of rocks similar to the Great Valley sequence near Loma Prieta (LP), Calif. A, Position of Loma Prieta relative to major fault systems and Mesozoic outcrop belts in west-central California and to well-dated Late Cretaceous outcrops of similar age at Stanford University (SU) and Pigeon Point (PP). $B$, Enlarged map showing the fault-bounded wedge of deformed Great Valley-like rocks and the four localities where the oyster bed or a similar faunal assemblage has

been found. Locality 1, M8575; locality 2, M8576; locality 3, M8525; locality 4, M6781 (see appendix for exact location information). Abbreviations are as follows: HF, Hooker fault; SSF, Soda Springs fault; BF, Berrocal fault; SAFZ, San Andreas fault zone; LFZ, Lomita fault zone; SFZ, Sargent fault zone. Faults are dashed where inferred. Modified from Bailey and others (1964), Rogers (1966), Dibblee and Brabb (1978), and McLaughlin and others (1988a). 


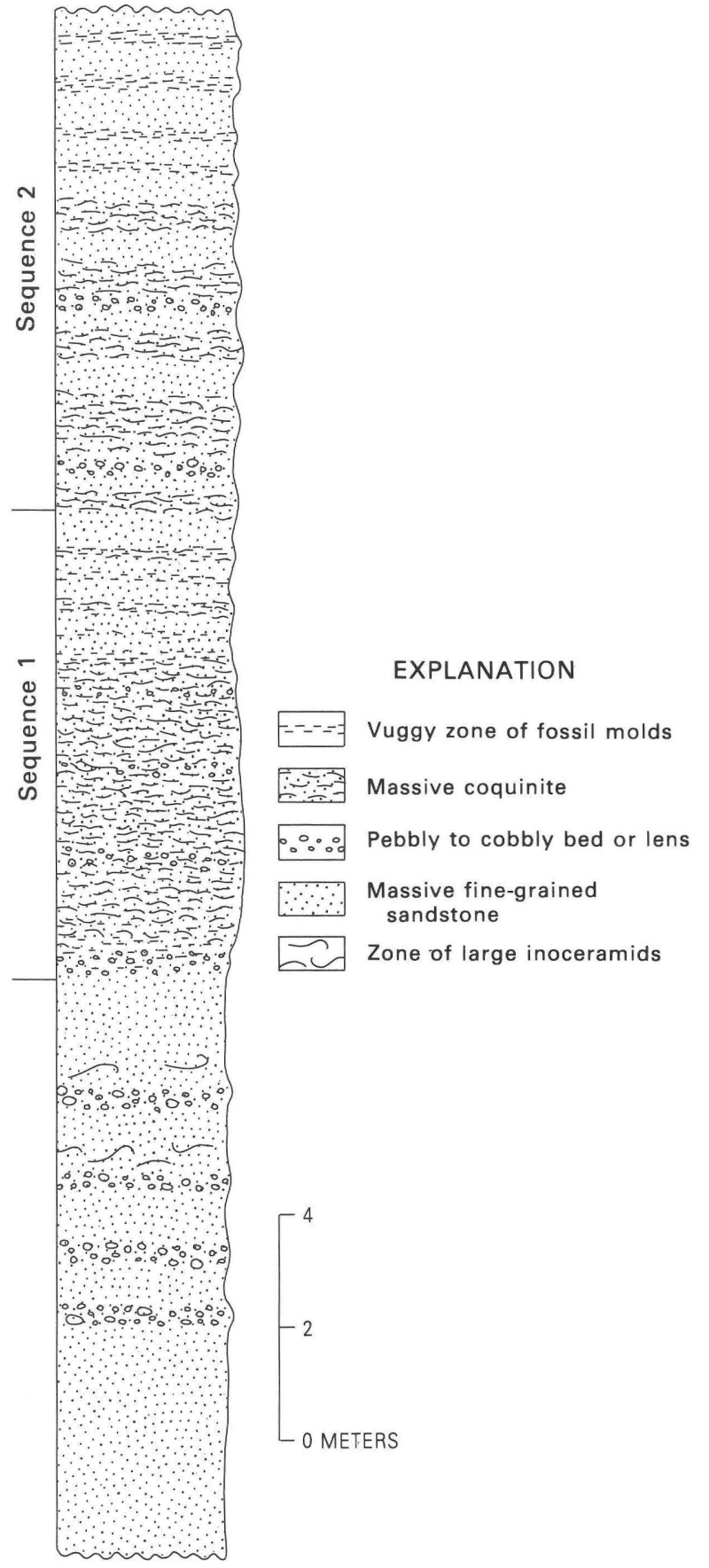

Figure 2. Oyster-rich zone at locality M8525 (text fig. 1, loc. 3 )

$1-3$ ) and may extend for at least another $6 \mathrm{~km}$ to the south, on the basis of the occurrence of several fossils near Sveadal (text fig. 1, loc. 4) that are associated with this bed at the other localities. At the one locality where the base of the oyster-rich interval is exposed, albeit poorly (text fig. 1, loc. 3), the basal part of the interval is a massive oyster coquinite containing pebbly to cobbly zones (text figs. 3,4 ) and is overlain by interbedded lenses of sandstone, pebbly

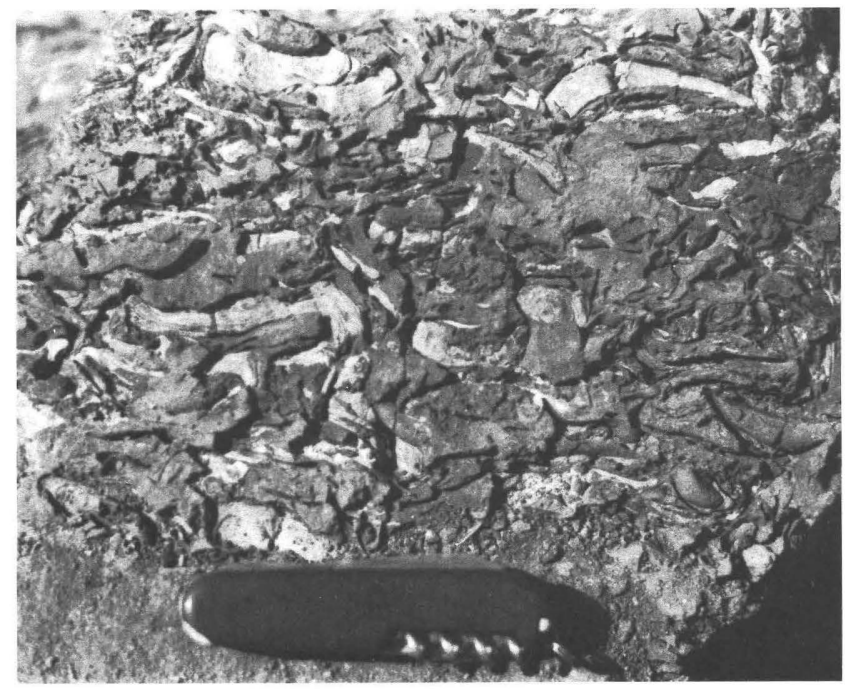

Figure 3. Cross-sectional view typical of the oyster-rich interval. Knife is $9 \mathrm{~cm}$ long.

sandstone containing rare cobble clasts, and coquinite or vuggy sandstone resulting from the dissolution of the shell material (text figs. 2, 5).

The repeated sandstone, pebbly sandstone, and faunally similar shell layers found through the interval shown in text figure 2 suggest that numerous turbidity flows deposited this unique oyster-rich zone, although it is possible that a single flow of fluctuating intensity also could have produced this depositional fabric. The fairly uniform assemblage in the oyster-rich zone is very different from the assemblages found in the overlying massive sandstone and argillite (although several species do occur in both of these facies) (see table 1) and thus reflects a change in source area, transport distance, or biofacies distribution between the facies. The mixing of abundant shell material into pebbly sandstone lenses in and above the generally massive oyster bed suggests that the shell material was not cemented at the time of transport. Although the disarticulation of all identifiable bivalve shells suggests that they were dead at the time of transport, the fact that many of the large thin-shelled Lima, Lyriochlamys, and "Mytilus" are unbroken implies minimal reworking before transport and little interaction between clasts entrained in the density flow.

\section{AGE AND CORRELATION}

Because the Upper Cretaceous rocks of the Sierra Azul have yielded no microfossils, macrofossils are the only source of age control presently available. Molluscan fossils associated with the oyster bed near the bottom of the Upper Cretaceous interval and the concretions present near the top of the sequence all indicate a late Campanian to early Maastrichtian age. The preponderance of molluscan fossils suggests a late Campanian age. 


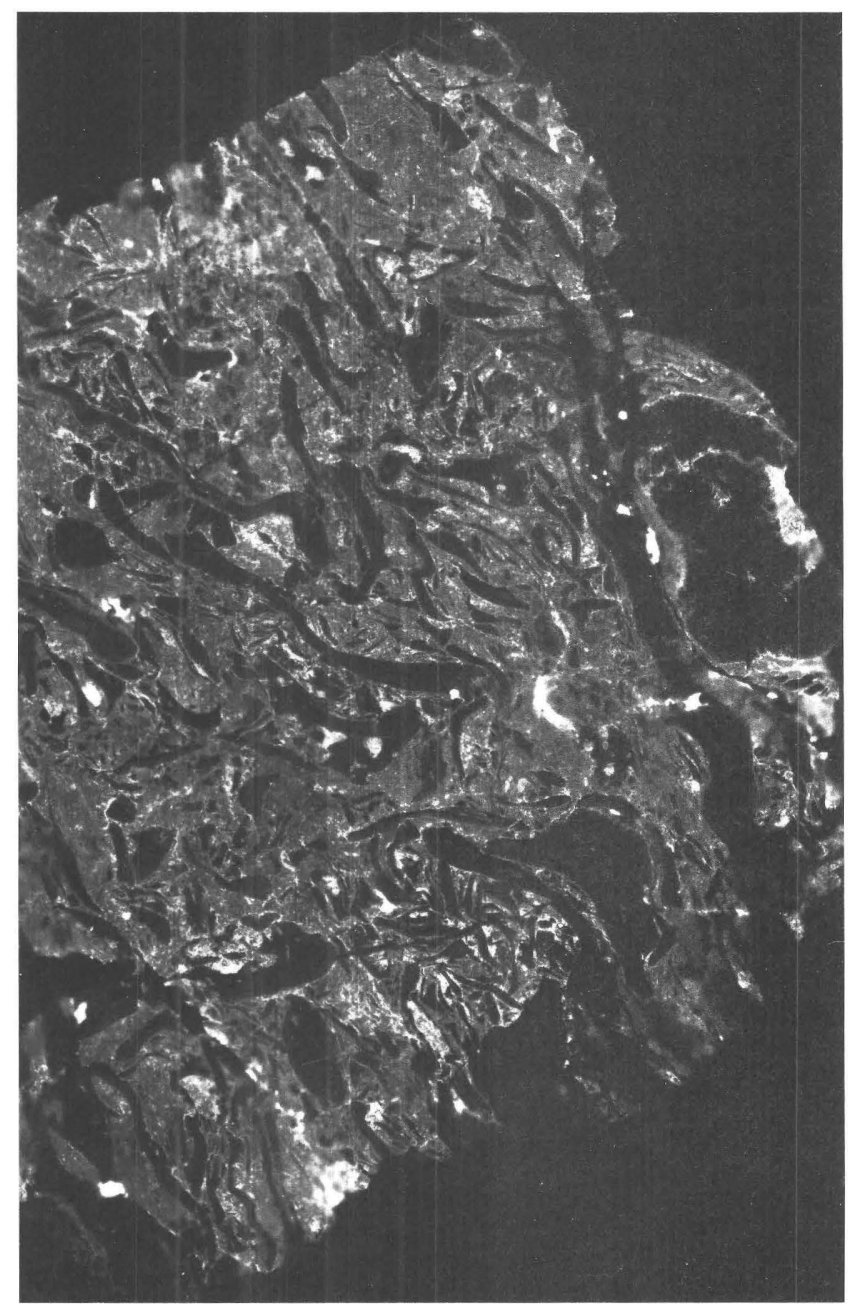

Figure 4. Print made from an acetate peel of the oyster coquinite showing the fabric of the bed. Dark areas are shell material (mostly Amphidonte shells). White areas are Calcispongea. Rounded, oblong, dark-gray area at right center is a Cyclostome bryozoan. The original upright orientation is unknown but probably was from the lower left to the upper right. Print is natural size.

Age information provided by fossils found in the oyster-rich interval is poorly constrained but is indicative of a late Campanian age. The component taxa Amphidonte (Amphidonte) parasitica (Gabb), Lyriochlamys traskii (Gabb), Hipponix dichotomus (Gabb), and poorly preserved Crassatella probably assignable to Crassatella conradiana (Gabb) all have their type locality at Texas Flat near Folsom, west of Sacramento, Calif. Matsumoto (1960) stated that the fossiliferous beds at this locality probably belong to the upper Campanian on the basis of the occurrence of Baculites inornatus Meek and $B$. occidentalis Meek in the Folsom area. Baculites inornatus also is found in concretions overlying the oyster-rich zone at Loma Prieta. Spondylus subnodosus (Packard) is a common element in the oyster beds and has its type locality in Packard's (1922) "Tellina" ooides zone of California's Santa Ana

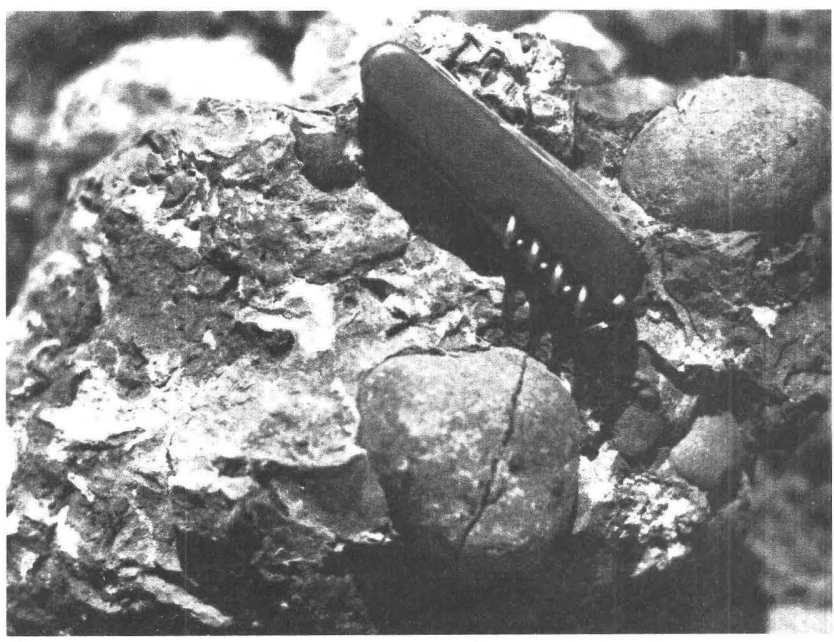

Figure 5. Pebbly to cobbly conglomeratic zone in the shell-bed interval. Knife is $9 \mathrm{~cm}$ long.

Mountains. This zone lies in the upper Campanian Metaplacenticeras pacificum ammonite zone (Popenoe, 1942; Matsumoto, 1960; Muller and Jeletzky, 1970).

A late Campanian age is suggested by other mollusks found both above and below the oyster beds. Inoceramus (Endocostea?) sp. aff. I. (E.?) cymbaeformis (Pergament) is found in sandstone immediately underlying the oyster-rich zone. Pergament $(1974,1978$, fig. 11) showed I. (E.?) cymbaeformis as occurring in the basal $I$. (E.) balticus zone in strata that probably lie in the uppermost Campanian of the eastern Soviet Union. In addition, the overlying massive sandstone unit contains Biplica obliqua (Gabb), Glycymeris (Glycymerita) anae Smith, and Clioscolus sp. cf. C. cordatus Whiteaves, all of which are characteristic of Campanian rocks (Popenoe, 1942, 1957; Smith, 1945; Bannon and others, 1989). Concretions in the overlying massive argillite unit contain Baculites rex Anderson, which is usually found in Maastrichtian strata but may range into the upper Campanian (Matsumoto, 1959). Inoceramus sp. aff. I. (E.) goldfussi (d'Orbigny) also is present in these concretions and is likewise indicative of a late Campanian to early Maastrichtian age. Baculites rex is found in some concretions of this interval with $B$. inornatus Meek and Baculites sp. aff. $B$. anceps Lamark, which are definitively known only from the upper Campanian in California (Matsumoto, 1959). Thus, the majority of biostratigraphic data indicates a late Campanian age for the Upper Cretaceous rocks at Loma Prieta. The 400 to $1,100 \mathrm{~m}$ of these rocks preserved in this region therefore appear to have been deposited in less than the approximately 7-m.y. late Campanian interval (Obradovich, 1988). On the basis of average sedimentation rates calculated for California Cretaceous deep-sea fan deposits by Ingersoll (1979), these strata may well have been deposited within a time interval of 2 to 4 m.y. 
Table 1. Checklist of macrofossils from the upper Campanian to lower Maastrichtian rocks near Loma Prieta, Calif. [X, present; -, not present; $c f$., comparable to; aff., affinities with; ?, questionable identification]

\begin{tabular}{|c|c|c|c|c|c|c|c|c|c|c|c|c|c|c|c|c|c|c|c|c|c|c|c|c|c|c|c|c|}
\hline Locality ${ }^{1}$ & $\begin{array}{c}\text { USGS } \\
\text { Mesozoic } \\
\text { locality }\end{array}$ & Quadrangle $^{2}$ & $\mathrm{Age}^{3}$ & $\begin{array}{l} \\
\\
\\
\\
\end{array}$ & 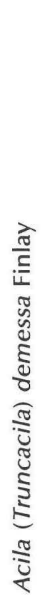 & 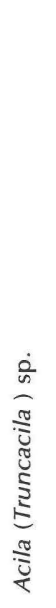 & 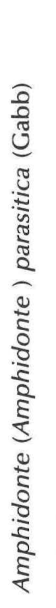 & 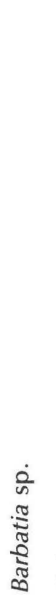 & $\begin{array}{l}0 \\
\frac{\dot{0}}{2} \\
\frac{\pi}{3}\end{array}$ & 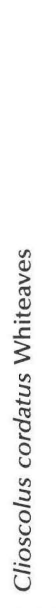 & 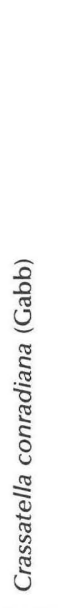 & . & 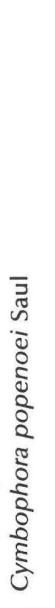 & $\begin{array}{l}\dot{0} \\
\text { n } \\
\frac{\pi}{0} \\
\frac{1}{2} \\
\vdots \\
\text { है }\end{array}$ & $\begin{array}{l} \\
\\
\dot{0} \\
\tilde{\Xi} \\
\tilde{\Xi}\end{array}$ & 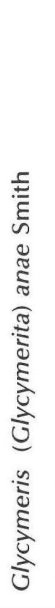 & $\begin{array}{l}0 \\
\dot{2} \\
0 \\
\vdots \\
\vdots \\
\vdots \\
\frac{0}{0} \\
0 \\
0\end{array}$ & 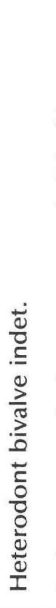 & 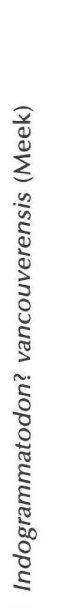 & 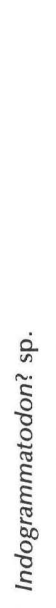 & 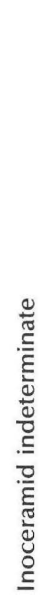 & 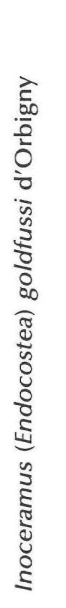 & 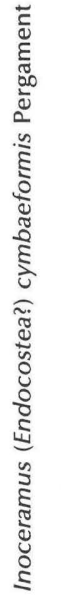 & $\begin{array}{l}\dot{0} \\
\omega \\
5 \\
\delta \\
\delta \\
\delta \\
50 \\
\delta \\
\infty\end{array}$ & $\begin{array}{l} \\
\\
< \\
\dot{0} \\
\dot{\omega} \\
\dot{\Sigma} \\
\tilde{\Xi} \\
\xi\end{array}$ & 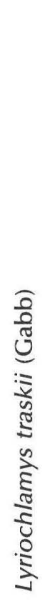 & 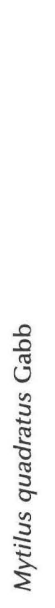 & $\begin{array}{l}\dot{0} \\
\tilde{D} \\
\stackrel{\Xi}{\Delta} \\
\tilde{n}\end{array}$ \\
\hline & M8575 & LG & C-M & $X$ & - & - & $X$ & - & - & - & - & $X$ & - & $X$ & - & - & $X$ & $X$ & - & - & - & - & - & - & - & - & - & - \\
\hline & M8576 & I & $-\mathrm{M}$ & $X$ & - & - & $\mathrm{x}$ & - & - & - & - & - & - & - & - & - & - & $X$ & - & - & $x$ & - & - & - & $X$ & $X$ & $c f$. & - \\
\hline & M8525 & LF & $-\mathrm{M}$ & $x$ & - & - & $\mathrm{X}$ & $\mathrm{X}$ & - & - & aff. & $\mathrm{X}$ & aff. & - & - & $x$ & - & - & - & $\mathrm{X}$ & - & aff. & aff. & $x$ & $X$ & $\mathrm{X}$ & - & $X$ \\
\hline \multirow[t]{9}{*}{$4 \ldots \ldots$} & M6781 & & & - & - & - & - & - & - & - & - & - & - & - & - & - & - & - & - & - & - & - & aff. & - & - & - & - & - \\
\hline & M8529 & LP & C-M & - & - & - & - & - & - & - & - & - & - & - & - & - & - & - & - & $\mathrm{X}$ & $x$ & - & - & - & - & - & - & $\mathrm{X}$ \\
\hline & & & & - & - & - & - & - & - & - & - & - & - & - & - & - & - & - & - & - & - & - & - & - & - & - & - & - \\
\hline & N & & & - & - & - & - & - & - & - & - & - & - & - & - & - & - & - & - & - & - & - & - & - & - & - & - & $X$ \\
\hline & M8554 & LP & C-M & - & - & $x$ & - & - & - & $c f$. & - & - & - & - & - & - & - & - & - & $X$ & - & $c f$. & - & - & - & - & - & $x$ \\
\hline & M8568 & LP & C-M & - & $X$ & - & - & - & $x$ & - & - & - & - & - & - & $X$ & - & - & $c f$. & - & - & - & - & - & - & - & - & - \\
\hline & M8524 & LP & C-M & - & $c f$. & - & - & - & $x$ & - & - & - & - & - & $?$ & $X$ & - & - & $c f$. & - & - & - & - & - & - & $x$ & - & - \\
\hline & & & & - & - & - & - & - & - & $c f$. & - & - & - & - & - & $X$ & - & - & - & - & - & - & - & - & - & - & - & - \\
\hline & M8540 & LP & C & - & - & - & - & - & - & - & $X$ & - & - & - & - & $X$ & - & - & aff. & - & - & - & - & - & - & - & - & \\
\hline
\end{tabular}

\footnotetext{
All locality data are listed in the appendix.

${ }^{2} \mathrm{LG}$, Los Gatos 71/2-min quadrangle; L, Laurel 71/2-min quadrangle; LP, Loma Prieta 71/2-min quadrangle.

${ }^{3} \mathrm{C}-\mathrm{M}$, Campanian to Maastrichtian; C, Campanian.
}

${ }^{1}$ Numbered localities are oyster-bed localities shown on text figure 1. Unnumbered localities are from the overlying sandy to argillaceous interval.

The nearest well-dated outcrops of rocks equivalent in age to the Upper Cretaceous rocks of the Sierra Azul are on the Stanford University campus and across the San Andreas fault at Pigeon Point (text fig. 1). A claystone cropping out near the Stanford campus contains foraminifers and macrofossils, including Baculites inornatus, of late Campanian age (Graham and Church, 1963). However, B. inornatus is apparently the only species to co-occur in the Stanford and Loma Prieta localities (Graham and Church (1963) have listed the Stanford macrofossils). Additionally, the claystone at Stanford contains much less sand and silt than the argillite at Loma Prieta does and is a light gray to gray green in color rather than the dark olive gray to olive black of the Loma Prieta rocks. These discrepancies imply different sediment source areas and depositional environments for the two localities and may be explained either by local changes in fan facies and feeder channel systems or by significant displacement on faults between these localities.

The age range of the Pigeon Point Formation is unclear (Saul, 1978, p. 50-52), but at least part of the formation is of late Campanian to early Maastrichtian age
(Hall and others, 1959; Saul, 1978, 1983). Although the lithologies of the Pigeon Point Formation and the Upper Cretaceous rocks of the Sierra Azul are similar, both largely reflecting a turbidite origin, the Pigeon Point Formation is much thicker (Howell and Joyce (1981) estimated a thickness of 3,300 m) and displays a regressive sequence ending in slope and, finally, shallow shelf deposits at the top of the preserved section (Howell and Joyce, 1981). This regressive sequence contrasts with the apparent transgression or shoreline retreat evident through the section near Loma Prieta. Macrofossils are typically rare in the Pigeon Point Formation but are locally abundant in the shelf facies. Of the approximately 66 species known from the Pigeon Point Formation and the 50 species known from the Upper Cretaceous rocks near Loma Prieta, only 8 to 10 species are common to both areas (Elder and Miller, 1989). Only one species is present at both areas but not known from elsewhere-the crab Archaeopus antennatus Rathbun, 1908.

The total amount of northward displacement of the Upper Cretaceous rocks of the Sierra Azul is uncertain, as 


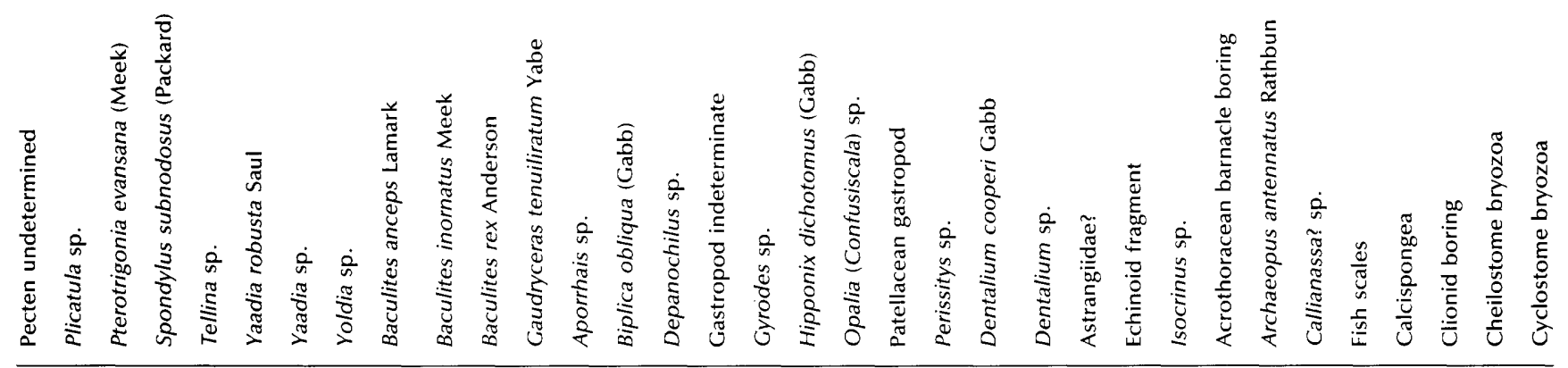

is the relative displacement between these strata and those to the west of the San Andreas fault in the Pigeon Point Formation. Paleomagnetic data for the Pigeon Point Formation imply $1,500 \mathrm{~km}$ or more of northward displacement before the suturing of the Salinian terrane to cratonal North America in the early Tertiary (Champion and others, 1984). McLaughlin and others (1988b) suggested more than 320 $\mathrm{km}$ of northward displacement for the Sierra Azul outlier between 60 and $52 \mathrm{Ma}$. In addition to these apparent Cretaceous to early Tertiary displacements, subsequent movement on the San Andreas and subsidiary faults has transported both the Pigeon Point Formation and the Upper Cretaceous rocks of the Sierra Azul northward relative to the North American craton. Graham and others (1989) have proposed between 300 and $330 \mathrm{~km}$ of post-Oligocene right-lateral displacement along the San Andreas fault in central California. In the San Francisco Bay area, this displacement has been distributed between the San Andreas fault and other faults to the west of Loma Prieta and subsidiary faults to the east, particularly the Calavaras and Hayward faults. Thus, it is difficult to determine not only the total displacement of the Upper Cretaceous rocks of the Sierra Azul but also the displacement of these strata relative to those of the Pigeon Point Formation to the west of the San Andreas fault.
One line of macrofaunal evidence suggests considerable displacement across the San Andreas fault, which lies between Loma Prieta and Pigeon Point. No specimens of the marginal Tethyan rudist, Coralliochama, have been found at Loma Prieta. This rudist is characteristic of upper Campanian to lower Maastrichtian strata to the west of the San Andreas fault from Punta Banda in northern Baja California to Gualala, near Point Arena, Calif., and has never been found to the east of the fault (Saul, 1986). Although the absence of Coralliochama at Loma Prieta is negative evidence and should not be relied upon too heavily, as the apparent absence of this rudist at Pigeon Point illustrates, this evidence nevertheless suggests considerable right-lateral displacement across the San Andreas fault to the west of Loma Prieta.

In addition, if significant right-lateral displacement has occurred to the east of Loma Prieta in the San Francisco Bay area, then the Upper Cretaceous rocks of the studied area should have been offset from those of the south-central to southern Diablo Range or points further south if there was significant pre-Eocene displacement along a pre-San Andreas transform. Rocks of late Campanian to early Maastrichtian age are widely distributed on the eastern side of the Diablo Range (Popenoe and others, 1960) and are locally present but poorly known on the western side of the 
range. Documentation of macrofossil assemblages from rocks of this age in the Diablo Range is outdated and sketchy, but the apparent lack of very near shore assemblages, like those present near Loma Prieta, in the turbidite facies flanking the Diablo Range suggests extensive transport of the Sierra Azul rocks from points further south, given the tectonic regime.

The assemblages at Loma Prieta do have a number of elements in common with those found in rocks of late Campanian to early Maastrichtian age from southern California (table 2). Strata of this age in the Simi Hills, the Santa Monica Mountains, and the Santa Ana Mountains share many common elements with the Loma Prieta molluscan fauna (Packard, 1916, 1922; Popenoe, 1937, 1942; Saul and Alderson, 1981), as does the basal part of the Point Loma Formation near San Diego (Sundberg, 1984; Sundberg and Riney, 1984; Bannon and others, 1989). However, a number of the species found at Loma Prieta also have been found in the Sacramento Valley and as far north as the Vancouver Island area in the upper Campanian to lower Maastrichtian Nanaimo Group (table 2) (Meek, 1876; Whiteaves, 1876-1903; White, 1889); this latter area also may have experienced some northward tectonic displacement (for example, McLaughlin and others, 1988b).

The most important influence on the oyster-bed assemblage near Loma Prieta appears to have been its near-shore proximity rather than its paleogeographic position on the Pacific coast. This influence is illustrated by a striking similarity between the Loma Prieta assemblage and one found near Folsom on the eastern side of the Sacramento Valley, as the co-occurring species mentioned earlier and several other probable co-occurring species indicate. The strata near Folsom consist of approximately $100 \mathrm{~m}$ of medium-grained sandstone deposited directly on granite (Popenoe and others, 1960) and apparently represent very near shore deposits. This near-shore depositional environment is supported by the reported presence of land snails mixed with the marine taxa (Anderson, 1958).

\section{CHARACTERISTIC MOLLUSCAN FOSSILS}

The oyster-rich assemblage is comprised of many bivalve taxa that are rare or previously unknown in California. The uncommon or unnamed bivalves include Isognomon sp., Lyriochlamys traskii (Gabb), Spondylus subnodosus (Packard), Acesta n.sp. A, Lima n.sp. A, Barbatia $\mathrm{sp}$., and Inoceramus (Endocostea?) sp. aff. I. (E.?) cymbaeformis Pergament. The taxonomies, occurrences, and ecologies of these and other molluscan taxa characteristic of this assemblage are discussed below.

\section{Barbatia sp.}

Plate 1, figures 2, 7, 9
At least one species of Barbatia is found in the oyster-rich interval. It is represented by four partial internal molds showing most of the hinge area but little of the cardinal area and three partial external molds showing ornamentation on the posterior half of shell. Barbatia sp. is a moderately large (the largest valve is about $75 \mathrm{~mm}$ long, $45 \mathrm{~mm}$ wide, and $17 \mathrm{~mm}$ thick), elongate, subquadrate form on which the beak is situated three-quarters of the way toward the anterior and on which the ventral margin is slightly to moderately incurved at midlength of the shell. The hingeline is slightly arcuate and has approximately 20 posterior and 8 anterior teeth that become moderately divergent at the distal ends. The external ornamentation consists of fine, slightly sinuous, radiating striae (every fifth to seventh being more deeply incised) and fine concentric growth lamellae; the intersection of these two features produces a reticulate, punctate appearance. The overall valve shape and orientation of the hinge teeth suggest that this species belongs to the subgenus Barbatia.

No Barbatia have been reported in rocks of this age on the Pacific slope or in Japan. Thus, this occurrence is probably a new species quite similar to Barbatia cochlearis Wade, 1926 and Barbatia fractura Wade, 1926, which are found in rocks of similar age on the gulf coast of the United States. The Loma Prieta species differs from these two species in having finer, less distinct radial ornamentation, primary and secondary radial striae, and a more broadly rounded anterior margin.

Barbatia species are byssate epifaunal nestlers that live in near-shore shallow-water environments (see Sundberg, 1980, fig. 21), where they may occupy exposed shallow depressions on firm substrates or attach to plants or rocks (Kauffman, 1969). The moderately concave ventral margin of the above species indicates a fairly large byssal gape and a strong byssal attachment, both of which imply adaptation to a relatively high energy environment.

\section{Mytilus sp. cf. M. quadratus Gabb, 1869}

Plate 1, figure 3

Mytilus sp. cf. M. quadratus is a moderately rare element in the oyster-rich interval. It is represented by one nearly complete internal mold and three incomplete external molds. Although several specimens of this species from Loma Prieta are considerably larger than the ones illustrated by Gabb (1869, pl. 31, fig. 87) and Stewart (1930, pl. 1, fig. 9), the Loma Prieta species is identical in shape and ornamentation to Mytilus quadratus (see Gabb (1869, p. 191) for description).

Although it is quite possible that several species have been attributed to Mytilus quadratus in the past, this species has been noted from Point Loma, near San Diego (Cooper, 1894), northward to the northern end of the Sacramento Valley near Horsetown (Diller, 1893) and throughout much 
Table 2. Geographic distribution of some selected taxa in the oyster beds near Loma Prieta, Calif.

[X, taxon present]

\begin{tabular}{|c|c|c|c|c|c|c|}
\hline Taxon $^{1}$ & $\begin{array}{l}\text { Vancouver } \\
\text { Island } \\
\text { area }\end{array}$ & Oregon & $\begin{array}{c}\text { Sacramento } \\
\text { Valley }\end{array}$ & $\begin{array}{l}\text { San Joaquin } \\
\text { Valley }\end{array}$ & $\begin{array}{l}\text { Santa Ana } \\
\text { Mountains }\end{array}$ & $\begin{array}{c}\text { San Diego } \\
\text { area }\end{array}$ \\
\hline Mytilus quadratus ................ & & & $X$ & $X$ & & $X$ \\
\hline 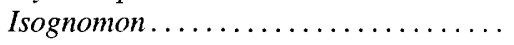 & $X$ & & $X$ & & & \\
\hline Lyriochlamys traskii .............. & $x$ & & $X$ & & & \\
\hline Spondylus subnodosus ............. & & & & $X$ & $X$ & $X$ \\
\hline Amphidonte parasitica $\ldots \ldots \ldots \ldots \ldots$ & $X$ & $X$ & $X$ & & & \\
\hline
\end{tabular}

'The following taxa are known only from the oyster-rich interval near Loma Prieta: Barbatia sp., Acesta n.sp. A, Lima n.sp. A, Inoceramus (Endocostea?) sp. aff. I. (E.?) cymbaeformis, and Astrangiidae? sp.

of the Diablo Range. Mytilus quadratus is most often associated with fossils of Campanian to Maastrichtian age but has been reported with fossils suggesting an age as old as Albian to Cenomanian (Diller, 1893).

Mytilus is an epifaunal, byssally attached bivalve. The broad, quadrate morphology and the orientation of the posterior adductor muscle on Mytilus sp. cf. M. quadratus is indicative of this epifaunal lifestyle (Stanley, 1970). Byssate, closely attached bivalves such as Mytilus and Modiolus most often inhabit the shallow sublittoral to littoral zones (see Sundberg, 1980, fig. 20) in areas of strong wave and current action (Kauffman, 1969).

\section{Isognomon sp.}

Plate 1, figures 1, 5

Isognomon sp. is a moderately rare element in the oyster-rich interval. It is represented by two nearly complete internal molds and one nearly complete external mold, as well as four other partial molds. This species is similar to I. excavata (White, 1889) in size and excavation of the anterior margin but appears to be less erect than the latter. It is unfortunate that neither growth lines nor the posterioventral margin is preserved on any of the Loma Prieta specimens; thus, detection of the posterioventral angulation and the flattening of the ventral margin noted by White (1889) on I. excavata is prevented. Specimens from Loma Prieta have long, straight hinges characterized by about 10 nearly equally spaced ligament pits about half as wide as the interspaces. The exterior of the valves was apparently nearly smooth.

Isognomon is a rare taxon in the Upper Cretaceous of the North American Pacific coast. It is represented by $I$. excavata on Vancouver Island (White, 1889) and from near Folsom, Calif. (Popenoe and others, 1960).

Isognomon is a byssate epifaunal bivalve that inhabits a range of shallow-water habitats, from exposed hard surfaces, such as plants or corals, to depressions or fissures in hard substrates (Kauffman, 1969; Stanley, 1970). More rounded or quadrate forms, like the species from Loma Prieta, tend to be fissure dwellers (Kauffman, 1969).
Inoceramus (Endocostea?) sp. aff. I. (E.?) cymbaeformis Pergament, 1974

Plate 1, figure 10; plate 2, figures $6,7,11$

Inoceramus (Endocostea?) sp. aff. I. (E.?) cymbaeformis is apparently a moderately common species in the sandstone and pebbly conglomerate interval developed immediately below the oyster-rich zone. Several partial to nearly whole molds of this species have been found at localities M8525 and M6781 (text fig. 1, appendix), and several specimens were illustrated by Bailey and Everhart (1964, fig. 49) from the southern branch of Almaden Canyon at an altitude of $700 \mathrm{~m}$. This species is characterized by the following: large size (exceeding $150 \mathrm{~mm}$ in height and $180 \mathrm{~mm}$ in width); a broad, enrolled umbo projecting $20 \mathrm{~mm}$ or more above the hinge of adult specimens; a long posterior wing having a broad flexure of the posterior margin and separated from the disc by a broad, shallow sulcus; surface ornament of subregular rugae near the umbo and irregular rugae and growth lamellae on the disc; and adult forms that are subquadrate in outline and that have nearly flat anterior and posteriodorsal margins separated from a very broadly convex to nearly straight ventral margin by moderate angulations. The inner rib characteristic of Endocostea has not been observed on any specimens.

These features are very distinctive and unlike those found on other inoceramids in the U.S. Geological Survey (USGS) collections at Menlo Park, Calif., or described for the Pacific Northwest, with the exception of Inoceramus-? illustrated by Meek (1876) from Vancouver Island. The Loma Prieta species has close affinities to Inoceramus cymbaeformis (see Pergament, 1974, pl. 45, figs. 9a, 9b) from the upper Campanian of the Bering Sea coastal region of the Soviet Union. It differs, however, in having neither as abrupt a change in growth direction nor the development of a pronounced pedestal at the change from early to late developmental stages and in having a flexure of the posterior margin that was not noted by Pergament (1974). The latter characteristic is similar to a characteristic of $I$. (Endocostea) cymba Böhm 1909, from the lower Campanian of northwestern Germany and the Black Hills of the 
United States (see Seitz, 1967), with which Pergament (1974) questioned the synonymy of his species. Thus, the species at Loma Prieta displays morphologic characteristics somewhat intermediate between these two taxa, suggestive of close taxonomic relations to both.

Inoceramids were byssally attached or free-living, epifaunal to semi-infaunal reclining bivalves that lived in a wide variety of environments (Kauffman, 1967; Stanley, 1970). The large lunule developed on the Loma Prieta specimens suggests that this species was byssally attached and rested on its anterior face, the commissure being in a nearly vertical position.

\section{Lyriochlamys traskii (Gabb), 1864}

Plate 1, figures 4, 6, 8: plate 2, figures 5, 8-10

Lyriochlamys traskii is a moderately common component of the oyster-rich interval and also has been found at one locality in the massive sandstone facies. It is represented by numerous partial internal and external molds. This moderately large pectinid (up to $90 \mathrm{~mm}$ in height and $70 \mathrm{~mm}$ in width) is characterized by numerous radiating squamous ribs and occasional interribs extending to the margins of the disc and onto the auricles and by Camptonectes-like divaricate striae between the ribs. Growth lamellae may be prominent on large specimens, forming squamae at their intersections with the radial ribs. The degree of ornamentation and the roundness of the disc are quite variable (see Gabb $(1864,1869)$ for additional description).

This species has been listed from as far south as San Diego (Cooper, 1894) and the Santa Ana Mountains (Sundberg, 1980) to as far north as the Vancouver Island area (Whiteaves, 1903), as well as at several localities in the Sacramento Valley (Gabb, 1864; Stanton, 1893). It generally is associated with faunas indicative of Campanian to early Maastrichtian age but may be present in midCretaceous strata of the Hornbrook Formation of northern California (Anderson, 1902). Lyriochlamys traskii is typically a rare faunal element where it has been found.

The deep byssal notch developed on the right valve of this species indicates strong byssal attachment, probably to a hard substrate. The squamose ribs suggest that it has adapted to a fissure-dwelling lifestyle, as many bivalves having a Chlamys-like morphology have done (Kauffman, 1969), although the generally undeformed morphology of the specimens suggests growth in an unconfined habitat.

\section{Spondylus subnodosus (Packard), 1922}

Plate 2, figures 1-4; plate 3, figures 8, 13

Spondylus subnodosus is a common faunal element in the oyster-rich beds. It is represented by numerous shells and molds. This species is characterized by large, inequivalve shells (specimens up to $100 \mathrm{~mm}$ high and $70 \mathrm{~mm}$ wide) having numerous radiating, flat-topped ribs. On some specimens, every fifth to seventh rib is more strongly developed and has small nodes. The radials are evident on the internal surfaces of small- to medium-sized specimens, becoming visible only on the peripheral regions of large shells. Broad rugae are present on the one right valve collected at Loma Prieta, and narrow, sharp rugae are present on the periphery of large left valves. Packard (1922) described this species as both Spondylus striatus Packard, 1922 and Lima subnodosa Packard, 1922 (see Packard (1922) for further description). Hanna (1924) pointed out that $S$. striatus Packard is a junior homonym but apparently failed to recognize $L$. subnodosa as a synonym for the above and replaced $S$. striatus Packard with $S$. fucatus Hanna, 1924. In accord with the International Code of Zoological Nomenclature (1985, article 60b), the name $S$. subnodosus is adopted for this species, and $S$. fucatus Hanna, 1924 becomes a junior synonym.

In addition to the Santa Ana Mountains where the type locality of Spondylus subnodosus is found, it has been recorded from near San Diego (Sundberg, 1984; Sundberg and Riney, 1984). Spondylus probably attributable to this species also have been found in rocks of the lower Maastrichtian Rosario Formation in Baja California (Anderson and Hanna, 1935; Anderson, 1958). Spondylus fragments are rare elements in several Menlo Park USGS collections from Campanian rocks of the San Joaquin Valley.

Spondylus are cementing epifaunal bivalves that attach to hard substrates by their larger right valves. Cretaceous as well as modern Spondylus typify high-energy wave- or current-dominated environments, as their occurrence in the Cretaceous on the upper surfaces of boulders on a rocky coast and on reef tops illustrates (Surlyk and Christensen, 1974). The much greater number of left valves relative to right valves found at Loma Prieta suggests that the more robust right valves tended to remain cemented to near-shore rocks after death, whereas the left valves became detached after breakdown of the ligaments and were transported offshore and downslope by turbidity currents.

\section{Acesta n.sp. A}

Plate 3, figures $1-4,7,11,12$

Acesta n.sp. A is a common component of the oyster-rich interval and is represented by numerous specimens. This species is characterized by the following: a large (to over $120 \mathrm{~mm}$ high and $60 \mathrm{~mm}$ wide), thin, elongate, equivalve shell that is smooth for the first 10 to $20 \mathrm{~mm}$ and then has numerous slightly wavy, radiating ribs (typically 45 to 55) and concentric growth lamellae that form a squamose texture at their intersections; a nearly straight anterior face extending down three-quarters or more of the anterior margin and separated from the disc by a strong umbonal angulation and from a narrow, long, anterior auricle by a moderately sharp sulcus; a broad posterior auricle not distinctly separated from the disc; a moderately oblique resilifer immediately posterior to the beak; and 
growth lamellae but no radials visible on the internal surface of the shell. The broad, oblique ligamental pit and inequilateral shape of this species strongly suggest that it should by placed in the limiid genus Acesta. However, the ornament is unlike that characteristic of any subgenus of Acesta (see Moore, 1969; Vokes, 1963; Kauffman, 1964) and thus indicates the need for a new subgenus to be erected for this species. Acesta n.sp. A is similar in many respects to $A$. longa (Römer) 1841 from the Lower Cretaceous of Europe (Woods, 1904-13), as well as to "Lima" multiradiata Gabb, 1869 from the Paleocene of Lake County, California (Stewart, 1930). The Loma Prieta species apparently differs from " $L$." multiradiata in having fewer ribs and in developing a squamose texture at an earlier stage than the specimen illustrated by Stewart (1930, fig. 2) and is more elongate and erect than the specimens illustrated by Dickerson (1914, pl. 8, fig. 1) or Stanton (1896, pl. 43, figs. 7 , $8)$.

The Limidae are byssally attached, epifaunal bivalves that are typically nestlers or fissure dwellers, but many also have the ability to swim for short periods (Kauffman, 1969; Stanley, 1970). Most Acesta in modern oceans are found in cool, deep- water environments, and little is known of their life habits (Vokes, 1963; Kauffman, 1964). However, Kauffman (1964) described three species of Acesta (Costellacesta) from Maastrichtian deposits of the Atlantic and gulf coasts of North America that contain a temperate shallow-water fauna, suggesting that at least some of this group may have had different habitat preferences in the past.

\section{Lima n.sp. A}

Plate 3, figures 5, 9

Lima n.sp. A is a moderately rare component of the oyster-rich beds and has been found only at locality M8576, where four specimens were collected. This species is characterized by a moderately small (to $27 \mathrm{~mm}$ high and 16 $\mathrm{mm}$ wide), trigonal, inequilateral shell having very fine, subsquamose radiating ribs extending to the beak and occasionally becoming dichotomous at distances greater than $10 \mathrm{~mm}$ from the beak on some specimens; this latter characteristic appears quite variable. A small anterior auricle is suggested on one specimen, and the posterior auricle apparently is not differentiated from the disc. However, the auricular region is poorly preserved on all specimens. This species is similar to Lima n.sp. illustrated by Sundberg (1984, pl. 1, fig. 2) from the Point Loma Formation but is apparently somewhat narrower and smaller and shows no indication of growth constrictions, as the latter specimen does. As noted above, this small Lima may have had a nestling or fissure-dwelling lifestyle.

\section{Amphidonte (Amphidonte) parasitica (Gabb), 1864}

Plate 3, figures 6,10 ; plate 4 , figures $9,17-23$

Amphidonte (A.) parasitica comprises the bulk of the fossils found in the oyster-rich interval, where it may represent over 90 percent of the bioclasts and forms a coquinite at places. Although this species is exceedingly abundant, very few decent specimens have been collected owing to characteristic fracturing and exfoliation of shell material. Good internal molds are reasonably common, but a good external mold has yet to be found. This species is characterized by a large (to $100 \mathrm{~m}$ high, $70 \mathrm{~mm}$ wide, and $10 \mathrm{~mm}$ thick), elongate, moderately inflated left valve having a low, strongly opisthocline beak, a large attachment area, a prominent spiral keel, and a lamellar surface. The right valve is nearly flat and displays concentric lamellae to squamae on the outer surface: one specimen shows faint radial striae on the posterioventral surface. Numerous chomata are developed along the entire anterior to ventral margin of both valves. Gabb (1864) and Stewart (1930) have provided further description.

This exogyrine bivalve is extremely variable in shape at Loma Prieta, as is characteristic of many oysters. This ecophenotypic variability of the oysters makes earlier reports of Amphidonte (A.) parasitica somewhat suspect. However, it has been cited as occurring at several localities in the Sacramento Valley and northward to the Vancouver Island area (see Anderson, 1958), most often in strata of late Campanian age.

Most cementing bivalves are found in shallow-water environments having depths of less than $35 \mathrm{~m}$ (Kauffman, 1969). The low profile and the robust shell and large attachment surface of Amphidonte (A.) parasitica imply that it was adapted to relatively shallow water, high-energy environments.

\section{Crassatella spp.}

Crassatella is a moderately rare element in the oyster-rich zone, where it is represented by eight specimens of at least two and probably three species. The specimens are all very poorly preserved molds that do not allow identification to the species level. The broad, protruding anterior margin and the broad, rounded posterior margin, as well as the hinge of some specimens (pl. 4, fig. 10), suggest that they belong to the $C$. conradiana group of Saul and Alderson (1981). However, the crenulated margin characteristic of this group is not evident on any of these specimens. In addition to the above species, a slightly inflated, elongate form having a crenulated margin is present.

The ecologic implications of these Crassatella are unclear. The elongate, slightly inflated form indicates adaptation for deeper and more rapid burrowing than the form of the $C$. conradiana group (see Kauffman, 1969, fig. 90 ) and thus suggests a more shallow water habitat for the former relative to the latter species. This interpretation is consistent with Saul and Alderson's (1981) observations that the slightly inflated, elongate $C$. saulae group is typically associated with a more shallow water fauna than the more inflated $C$. conradiana group, although the two 
may be found together. On the whole, Crassatella apparently suggests a source area of slightly greater water depth than do most of the other faunal elements present in the oyster beds: Saul (1982) suggested that this genus is an indicator of moderate shelf depth in late Campanian molluscan assemblages of the Santa Ana Mountains.

\section{OTHER FAUNAL COMPONENTS}

In addition to the bivalve species noted above, several gastropod species are present, although all are represented by only one or two specimens. This rarity of gastropods seems unusual for the near-shore aspect of the fauna and may reflect only the extremely poor preservation of aragonitic shell material. In addition to a poorly preserved specimen resembling Margarites ornatissimus (Gabb), 1864 , the presence of two moderately well preserved patelliform gastropod species is worthy of note. One species appears to be referable to the Mesogastropoda species Hipponix dichotomus (Gabb), 1864, (pl. 4, figs. 7, 8). The other species probably belongs to the Archeogastropoda superfamily Patellacea (pl. 4, figs. 4, 5). As with many of the bivalve taxa, the type locality for $H$. dichotomus is Texas Flat. This species also has been reported from the Point Loma Formation near San Diego (Cooper, 1894). The presence of Patellacea suggests a rocky, near-shore habitat within the photic zone, because modern patelliform Archeogastropoda feed on seaweeds on rocky surfaces (Kanie, 1975).

The oyster-rich assemblage also contains several unusual nonmolluscan components. One important member of this assemblage is a ramus sponge (pl. 4, figs. 11-15) probably belonging to the Calcispongea (J. Keith Rigby, oral commun., 1989), given the presence on some specimens of acrothoracian barnacle borings (pl. 4, fig. 13), which are known only from carbonate substrates (Seilacher, 1969). This sponge may account for up to 30 percent of the bioclasts in some portions of the oyster-rich zone. Calcispongea are associated with shallow-water beds and reefy beds throughout the fossil record but are particularly characteristic of greensand facies in the Cretaceous; they are also common in chalky rocks of this age (Finks, 1983). These sponges are indicative of clear water, full oceanic salinity, and depths of probably less than $100 \mathrm{~m}$ and more likely less than $30 \mathrm{~m}$; modern species are most common at depths of less than $10 \mathrm{~m}$ (deLaubenfels, 1957a, b). Growth of this fairly delicate ramus sponge probably could not have occurred in highly turbulent conditions, and occasional flabellate morphology (pl. 4, fig. 15) suggests uniform current conditions (Bidder, 1923).

In addition to the Calcispongea, one or more species of boring clionid sponge are indicated in the oyster beds by the abundant occurrence of several species of the ichnogenus Entobia (pl. 5, figs. 13, 14, 18; also probably fig. 6).
These sponge borings were most common in the Amphidonte and Spondylus shells, which were thicker than other shells present in these beds.

Another unusual component in these beds is an encrusting colonial coral, probably referable to the Astrangiidae. Three specimens of this species have been found (pl. 5, figs. 1, 2). This coral has not been previously described or illustrated in California. The Astrangiidae are ahermatypic corals that are widely distributed in littoral to neritic zones in temperate to tropical seas (Vaughn and Wells, 1943). Also, an encrusting Cheilostome bryozoan is commonly found on shells in these beds, particularly on the inside of Amphidonte shells (pl. 4, fig. 16), and several specimens of a Cyclostome bryozoan have been found. The presence of these typically stenohaline, encrusting organisms is indicative of full marine salinity and sedimentation rates low enough for their establishment and survival before burial and (or) downslope transport.

Another stenohaline group, the Echinodermata, is represented in the oyster-rich interval by rare occurrences of poorly preserved Isocrinus columnal plates and by fragments of several echinoid taxa. One of the latter species belongs to a cidaroid genus, as its large, stout spines indicate (pl. 4, figs. 1-3).

The Crustacea are represented in the oyster-rich zone by acrothoracian barnacle borings, mostly assignable to the ichnogenus Rogerella (pl. 5, figs. 15, 17). These borings are common and may be found on almost every bivalve species present, as well as on some calcisponge specimens. One fragmentary crustacean manus, probably assignable to Callianassa, also has been found in this zone (pl. 4, fig. 6). The shape and ornamentation of this manus are very similar to those shown for C. stimpsonii Gabb, 1864, (Gabb, 1864, pl. 9, fig. 1).

In addition to the groups noted above, the molds of several small, coiled tubes attached to the surface of shells for nearly their entire length apparently reflect the presence of a Spirorbis-like serpulid worm (pl. 5, figs. 7, 11). The Annelida also may be represented by boring polychaete worms. Their presence is reflected by rare meandering and U-shaped borings running parallel to shell surfaces and resembling Maeandropolydora (pl. 5, figs. 10, 12, 16).

Several other borings and traces of unknown affinities are found in voids created by the dissolution of shells in the oyster beds. Long, deep sac-shaped or arcuate borings that penetrate the entire thickness of Spondylus? or possibly wood molds and that have oblique constrictions may be the result of boring bivalves (Gastrochaenolites?) (pl. 5, figs. $5,8,9$ ). One possible example of algal microboring (pl. 5 , fig. 3) indicates, if correct, that the shell fragment was in the photic zone at the time of boring. Also, a rasplike trace of possible isopod or gastropod origin was found on the internal surface of a Spondylus shell (pl. 5, fig. 4), and an unusual dendritic pattern developed on the surface of a shell mold (pl. 5, fig. 11) may reflect another type of bryozoan. 


\section{PALEOECOLOGIC AND PALEOBIOGEOGRAPHIC CONCLUSIONS}

The degree of community mixing within the oysterrich assemblage is unknown, but it is not unreasonable to assume that most or all of the component taxa lived in close proximity to one another. This assemblage is characterized by molluscan taxa that are indicative of near-shore, relatively high energy environments. Many of the components suggest a rocky near-shore setting inhabited by cementing bivalves and nestling to fissure-dwelling byssate bivalves. Taxa indicative of this environment include Spondylus, Mytilus, Barbatia, Lima, Lyriochlamys, Isognomon, and the patelliform gastropods. Other elements suggest a relatively near shore habitat having a sandy to gravelly substrate. Taxa in this group include Amphidonte, Yaadia. Crassatella, and Glycymeris. The presence of the delicate ramus sponges, which grew on hard objects on the substrate, suggests a sublittoral environment having moderate wave or current energy. It is possible that Amphidonte "oyster reefs" were developed on a relatively fine grained substrate and thereby facilitated habitation of the many component taxa that required hard substrates for attachment. Alternatively, the assemblage may reflect a broad source area of mixed rocky and sandy coastal habitats having water depths below the breaker line but probably near or above wave base. Either of the above hypotheses implies extensive offshore transport by density currents to the probable continental rise setting characteristic of turbidite deposition.

The absence of many of the near-shore taxa noted above, plus the common to abundant occurrence of $\mathrm{BaCu}$ lites and other rare ammonites, Acila, Indogrammatodon?, and Inoceramus in the massive sandstone and argillite facies overlying the oyster beds (table 1), suggests a more offshore source environment for those facies than for the oyster-rich zone. Saul and Alderson (1981) have noted that the above assemblage is characteristic of fine-grained sediments throughout California and is thus probably indicative of low-energy, relatively offshore environments. These taxa, with the exception of Acila, also form the core of Russell and others' (1986) assemblage characteristic of Upper Cretaceous outer shelf to slope deposits in California.

Unfortunately, the full paleoecologic and paleobiogeographic implications of the taxa present in the oysterrich beds at Loma Prieta are difficult to ascertain because of their transported nature and their scattered distribution and rare occurrences elsewhere (table 2 lists the west coast distributions of some taxa). Many of the species present have ranges from southern California, through the Central Valley, and extending to the Vancouver Island area of British Columbia; species in the latter area may have experienced some northward tectonic transport since the late Campanian (for example, McLaughlin and others, 1988b). Exceptions are Spondylus subnodosus, which has been reported only in southern California, and Amphidonte parasitica, which has been noted only from northern California to British Columbia.

On the whole, the taxa present in the Upper Cretaceous rocks of the Sierra Azul imply temperate to warmtemperate oceanic conditions. Species indicative of a Tethyan influence, such as the rudists that are found in rocks of this age west of the San Andreas fault, are yet to be found at Loma Prieta. Given the strong near-shore aspect of the oyster-rich assemblage, rudist fragments would be a likely component if they were living commonly at the paleolatitude of the source area. Their absence suggests the aforementioned extensive northward transport of the rocks west of the San Andreas fault relative to Loma Prieta but does not negate considerable northward displacement of Loma Prieta since the Late Cretaceous. Indeed, extensive tectonic displacement of Loma Prieta is strongly suggested by the very near shore oyster-rich assemblage found there but not known from turbidite facies of the Diablo Range. Although the latter should have been more proximal to near-shore source areas, their assemblages appear to be more offshore than those present in the oyster-rich interval near Loma Prieta.

In conclusion, the overriding influence on the composition of the oyster-rich assemblage at Loma Prieta appears to be its near-shore origin. The rarity of near-shore deposits of late Campanian to early Maastrichtian age in California may account for the fact that this assemblage is not widely developed in the State. The marked similarity of the Loma Prieta assemblage to the assemblage found in near-shore deposits near Folsom, Calif., suggests that this assemblage may have been present in similar habitats throughout California but was rarely preserved in the rock record. Additional documentation of complete fossil assemblages from the entire Pacific Northwest will allow a more complete analysis of the paleobiogeographic and paleoecologic information contained in the Upper Cretaceous rocks of the Sierra Azul and elsewhere.

\section{REFERENCES CITED}

Anderson, F.M., 1902, Cretaceous deposits of the Pacific coast: Proceedings of the California Academy of Sciences, $3 \mathrm{~d}$ ser., v. 2, no. 1,155 p., 12 pls.

1958, Upper Cretaceous of the Pacific Coast: Geological Society of America Memoir 71, 378 p., 75 pls.

Anderson, F.M., and Hanna, G.D., 1935, Cretaceous geology of lower California: Proceedings of the California Academy of Sciences, 4th ser., v. 23, p. 1-34, 11 pls.

Arnold, R., 1908, Descriptions of new Cretaceous and Tertiary fossils from the Santa Cruz Mountains, California: Proceedings of the U.S. National Museum, v. 34, no. 1617, p. $345-359,6$ pls.

Bailey, E.H., and Everhart, D.L., 1964, Geology and quicksilver deposits of the New Almaden District, Santa Clara County, 
California: U.S. Geological Survey Professional Paper 360 , 206 p., 18 pls.

Bailey, E.H., Irwin, W.P., and Jones, D.L., 1964, Franciscan and related rocks, and their significance in the geology of western California: California Division of Mines and Geology Bulletin 183, 177 p.

Bannon, J.L., Bottjer, D.J., Lund, S.P., and Saul, L.R., 1989, Campanian/Maastrichtian stage boundary in southern California: Resolution and implications for large-scale depositional patterns: Geology, v. 17, p. 80-83.

Bidder, G., 1923, Relation of the form of a sponge to its currents: Quarterly Journal of Microscopic Sciences, v. 67, pt. 2, p. 293-323.

Böhm, J., 1909, Über Inoceramus Cripsi auctorum, in Schroeder, H., and Böhm J., eds., Geologie und Paläontologie der subhercynen Kreidemulde: Abhandlungen der Königlich Preussischen Geologischen Landesanstalt, neue folge, v. 56, p. 39-58, 6 pls.

Bottjer, D.J., and Link, M.H., 1984, A synthesis of Late Cretaceous southern California and northern Baja California paleogeography, in Crouch, J.K., and Bachman, S.B., eds., Tectonics and sedimentation along the California margin: Society of Economic Paleontologists and Mineralogists, Pacific Section, Book 38, p. 171-188.

Champion, D.E., Howell, D.G., and Gromme, C.S., 1984, Paleomagnetic and geologic data indicating $2500 \mathrm{~km}$ of northward displacement for the Salinian and related terranes, California: Journal of Geophysical Research, v. 89, no. B9, p. $7736-7752$.

Cooper, J.G., 1894, Catalogue of Californian fossils, pts. 2-5: California State Mining Bureau Bulletin 4, 65 p., 6 pls.

deLaubenfels, M.W., 1957a, Marine sponges: Geological Society of America Memoir 67, v. 1, p. 1083-1086.

1957b, Sponges of the post-Paleozoic: Geological Society of America Memoir 67, v. 2, p. 771-772.

Dibblee, T.W., Jr., and Brabb, E.E., 1978, Preliminary geologic map of the Chittenden, Los Gatos, and Watsonville East quadrangles, California: U.S. Geological Survey Open-File Report 78-453, 3 sheets, scale 1:24,000.

Dickerson, R.E., 1914, Fauna of the Martinez Eocene of California: University of California Publications in Geological Sciences, v. 8, p. 61-180.

Diller, J.S., 1893, Cretaceous and Early Tertiary of northern California and Oregon: Geological Society of America Bulletin, v. 4, p. 205-225.

Elder, W.P., and Miller, J.W., 1989, Checklist of Mesozoic macrofossil localities in the Santa Cruz Mountains and vicinity: U.S. Geological Survey Open-File Report 89-543, 8 p., 1 pl., 3 tables.

Finks, R.M., 1983, Pharetronida: Inozoa and Sphinctozoa, in Broadhead, T.W., ed., Sponges and spongiomorphs, notes for a short course organized by J.K. Rigby and C.W. Stearn: University of Tennessee Department of Geological Sciences Studies in Geology 7, p. 55-69.

Gabb, W.M., 1864, Descriptions of the Cretaceous fossils, in Paleontology of California: Sacramento, California Geological Survey, v. 1, p. 57-243, 24 pls.

1869, Cretaceous and Tertiary fossils, in Paleontology of California: Sacramento, California Geological Survey, v. 2, sec. 2, p. 127-205, 17 pls.
Graham, J.J., and Church, C.C., 1963, Campanian foraminifera from the Stanford University campus, California: Stanford University Publications, Geological Sciences, v. 8, no. 1, 107 p., 8 pls.

Graham, S.A., Stanley, R.G., Bent, J.V., and Carter, J.B., 1989 , Oligocene and Miocene paleogeography of central California and displacement along the San Andreas fault: Geological Society of America Bulletin, v. 101, p. 711-730.

Hall, C.A., Jones, D.L., and Brooks, S.A., 1959, Pigeon Point Formation of Late Cretaceous age, San Mateo County, California: American Association of Petroleum Geologists Bulletin, v. 43, p. 2855-2865.

Hanna, G.D., 1924, Rectifications of nomenclature: Proceedings of the California Academy of Sciences, 4th ser., v. 13, no. 10 , p. 151-186.

Howell, D.G., and Joyce, J.M., 1981, Field guide to the Upper Cretaceous Pigeon Point Formation, in Howell, D.G., and McDougall, K.A., eds., Cretaceous geology of the California Coast Ranges, west of the San Andreas fault: Society of Economic Paleontologists and Mineralogists, Pacific Section, p. $61-70$.

International Code of Zoological Nomenclature, 1985: Berkeley and Los Angeles, University of California Press, 338 p.

Ingersoll, R.V., 1978, Submarine fan facies of the Upper Cretaceous Great Valley Sequence, northern and central California: Sedimentary Geology, v. 21, p. 205-230.

1979, Evolution of the Late Cretaceous forearc basin, northern and central California: Geological Society of America Bulletin, v. 90, p. 813-826.

Kanie, Y., 1975, Some Cretaceous patelliform gastropods from the northern Pacific region: Science Report of the Yokosuka City Museum, no. 21, 44 p., 20 pls.

Kauffman, E.G., 1964, Costellacesta, a new subgenus of Lima from the Cretaceous of the Gulf and Atlantic Coast Province: Tulane Studies in Geology and Paleontology, v. 2, p. 69-101, 1 pl.

1967, Coloradoan macroinvertebrate assemblages, central Western Interior, United States, in Kauffman, E.G., and Kent, H.E., eds., Paleoenvironments of the Cretaceous seaway in the Western Interior-A symposium: Golden, Colorado School of Mines, p. 67-143.

1969, Form, function and evolution, in Moore, R.C., ed., Treatise on invertebrate paleontology, pt. N, v. 1, Mollusca 6, Bivalvia: Boulder, Colo., Geological Society of America and University of Kansas Press, p. N129-N205.

Matsumoto, T., 1959, Upper Cretaceous ammonites of California, pt. I: Memoirs of the Faculty of Science, Kyushu University, ser. D, Geology, v. 8, no. 4, p. 91-171, 15 pls.

-1960, Upper Cretaceous ammonites of California, pt.III: Memoirs of the Faculty of Science, Kyushu University, ser. D, Geology, Special Volume II, 204 p., 2 pls.

McLaughlin, R.J., Clark, J.C., and Brabb, E.E., 1988a, Geologic map and structure sections of the Loma Prieta 71/2' quadrangle, Santa Clara and Santa Cruz Counties, California: U.S. Geological Survey Open-File Report 88-752, 32 p., 2 sheets, scale $1: 24,000$.

McLaughlin, R.J., Blake, M.C., Jr., Griscom, A., Blome, C.D., and Murchey, B., 1988b, Tectonics of formation, translation, and dispersal of the Coast Range ophiolite of California: Tectonics, v. 7, p. 1033-1056. 
Meek, F.B., 1876, Descriptions and illustrations of fossils from Vancouver's and Sucia Islands, and other northwestern localities: U.S. Geological and Geographical Survey of the Territories Bulletin, v. 2, p. 351-374, 6 pls.

Moore, R.C., 1969, ed., Treatise on invertebrate paleontology, pt. N., v. 1, Mollusca 6, Bivalvia: Boulder, Colo., Geological Society of America and University of Kansas Press, p. N1-N489.

Muller, J., and Jeletzky, J., 1970, Geology of the Upper Cretaceous Nanaimo Group, Vancouver and Gulf Islands, British Columbia: Geological Survey of Canada Paper 69-25, 77 p.

Nilsen, T.H., 1980, Modern and ancient submarine fans: Discussion of papers by R.G. Walker and W.R. Normark: American Association of Petroleum Geologists Bulletin, v. 64, p. 1094-1101.

Normark, W.R., 1978, Fan-valleys, channels and depositional lobes on modern submarine fans: Characters for the recognition of sandy turbidite environments: American Association of Petroleum Geologists Bulletin, v. 62, p. 912-931.

Obradovich, J.D., 1988, A different perspective on glauconite as a chronometer for geologic time scale studies: Paleoceanography, v. 3, p. 757-770.

Packard, E.L., 1916, Faunal studies in the Cretaceous of the Santa Ana Mountains of southern California: University of California Publications, Bulletin of the Department of Geology, v. 9. no. 12, p. 137-159.

1922, New species from the Cretaceous of the Santa Ana Mountains, California: University of California Publications in Geological Sciences, v. 13, no. 10, p. 413-462, 15 pls.

Pergament, M.A., 1974, Biostratigraphy and inocerams of Senonian (Santonian-Maastrichtian) of the USSR Pacific regions [in Russian]: Transactions of the Geological Institute of the USSR Academy of Sciences, Trudy, v. 260, 211 p., 46 pls.

1978, Upper Cretaceous stratigraphy and inocerami of the northern hemisphere [in Russian]: Transactions of the Geological Institute of the USSR Academy of Sciences, Trudy, no. $322,200 \mathrm{p}$.

Popenoe, W.P., 1937, Upper Cretaceous mollusca from southern California: Journal of Paleontology, v. 11, p. 379-402, 5 pls.

1942, Upper Cretaceous formations and faunas of southern California: American Association of Petroleum Geologists Bulletin, v. 26, p. 162-187.

1957, The Cretaceous gastropod genus Biplica: University of California Publications in Geological Sciences, v. 30, p. 425-454, 2 pls.

Popenoe, W.P., Imlay, R.W., and Murphy, M.A.. 1960, Correlation of the Cretaceous formations of the Pacific coast (United States and northwestern Mexico): Geological Society of America Bulletin, v. 71, p. 1491-1540.

Rathbun, M.J., 1908, Descriptions of fossil crabs from California: Proceedings of the U.S. National Museum, v. 35, p. 341-349, pls. $45-49$.

Rogers, T.H., 1966, Geologic map of California, San Jose sheet: San Francisco, California Division of Mines and Geology, scale 1:250,000.

Römer, F.A., 1841, Die Versteinerungen des norddeutschen Kreidegebirges: Hannover, 146 p.

Russell, J.S., Baum, S.L., and Watkins, R., 1986, Late Coniacian to early Campanian clastic shelf deposits and molluscan assemblages of the northeastern Sacramento Valley, California, in Abbott, P.L., ed., Cretaceous stratigraphy, western North America: Society of Economic Paleontologists and Mineralogists, Pacific Section, Book 46, p. 179-196.

Saul, L.R., 1978, The North Pacific Cretaceous trigoniid genus Yaadia: University of California Publications in Geological Sciences, v. 119,65 p., 12 pls.

1982, Water depth indications from Late Cretaceous mollusks. Santa Ana Mountains, California, in Bottjer, D.J., Colburn, I.P., and Cooper, J.D., eds., Late Cretaceous depositional environments and paleogeography, Santa Ana Mountains, southern California: Society of Economic Paleontologists and Mineralogists, Pacific Section, Book 24, p. 69-76.

1983, Turritella zonation across the Cretaceous-Tertiary boundary, California: University of California Publications in Geological Sciences, v. 125, 165 p., 7 pls.

1986, Pacific Coast Cretaceous molluscan faunas: Time and aspect of changes, in Abbott, P.L., ed., Cretaceous stratigraphy, western North America: Society of Economic Paleontologists and Mineralogists, Pacific Section, Guidebook, p. 131-136.

Saul, L.R., and Alderson, J.M., 1981, Late Cretaceous mollusca of the Simi Hills: An introduction, in Link, M.H., Squires, R.L., and Colburn, I.P., eds., Simi Hills Cretaceous turbidites, southern California: Society of Economic Paleontologists and Mineralogists, Pacific Section, Fall Field Trip Guidebook, p. 29-41.

Seilacher. A., 1969, Paleoecology of boring barnacles: American Zoologist, v. 9, p. 705-719.

Seitz, O., 1967, Die Inoceramen des Santon und Unter-Campan von Nordwestdeutschland, pt. 3: Geologisches Jahrbuch, v. 75 , p. 171 p., 27 pls.

Simoni, T.R., Jr., 1974, Geology of the Loma Prieta area, Santa Clara and Santa Cruz Counties, California: San Jose, California State University, unpublished M.Sci. thesis, 75 p.

Smith, C.T., 1945. The biostratigraphy of Glycymeris veatchii in California: Journal of Paleontology, v. 19, p. 35-44.

Stanley, S.M., 1970, Relation of shell form to life habits of the Bivalvia (Mollusca): Geological Society of America Memoir 125, 296 p., pls. $1-40$.

Stanton, T.W., 1893, The fauna of the Shasta and Chico formations: Geological Society of America Bulletin, v. 4, p. 245-256.

1896, The faunal relations of the Eocene and Upper Cretaceous on the Pacific coast: U.S. Geological Survey 17th annual report, pt. 1, p. 1005-1060, pls. 63-67.

Stewart, R.B., 1930, Gabb's California Cretaceous and Tertiary type Lamellibranchs: Academy of Natural Sciences of Philadelphia Special Publication 3, 314 p., 17 pls.

Sundberg, F.A., 1980, Late Cretaceous paleoecology of the Holz Shale, Orange County, California: Journal of Paleontology, v. 54, p. $840-857$.

1984, Upper Cretaceous macro-fossils of San Diego, in Abbott, P.L., ed., Upper Cretaceous depositional systems, southern California, northern Baja California: Society of Economic Paleontologists and Mineralogists, Pacific Section, Book 36, p. 37-40.

Sundberg, F.A., and Riney, B., 1984, Preliminary report on the Upper Cretaceous macro-invertebrate faunas near Carlsbad, 
California, in Abbott, P.L., ed., Upper Cretaceous depositional systems, southern California, northern Baja California: Society of Economic Paleontologists and Mineralogists, Pacific Section, Book 36, p. 103-107.

Surlyk, F., and Christensen, W.K., 1974, Epifaunal zonation on an Upper Cretaceous rocky coast: Geology, v. 2, p. 529-534.

Vaughn, T.W., and Wells, J.W., 1943, Revision of the suborders, families, and genera of the Scleractinia: Geological Society of America Special Paper 44, 363 p., 51 pls.

Vokes, H.E., 1963, Studies on Tertiary and Recent giant Limidae: Tulane Studies in Geology, v. 1, p. 75-92, 2 pls.

Wade, B., 1926, The fauna of the Ripley Formation on Coon Creek, Tennessee: U.S. Geological Survey Professional Paper 137, 272 p., 72 pls.

Walker, R.G., 1978, Deep water sandstone facies and ancient submarine fans: Models for exploration for stratigraphic traps: American Association of Petroleum Geologists Bulletin, v. 62 , p. $932-966$

1984, Turbidites and associated coarse clastic deposits, in Walker, R.G., ed., Facies models ( 2 d ed.): Geoscience Canada Reprint Series 1, p. 171-188.

White, C.A., 1889, On invertebrate fossils from the Pacific coast: U.S. Geological Survey Bulletin 51, 102 p., 14 pls.

Whiteaves, J.F., 1876-1903, Mesozoic fossils: Ottawa, Ont., Geological Survey of Canada, v. 1, pts. 1-5, 415 p., 51 pls. -1903, Mesozoic fossils, pt. 5, On some additional fossils from the Vancouver Cretaceous, with a revised list of species therefrom: Ottawa, Ont., Geological Survey of Canada, v. 1, p. $310-415$, pls. $40-51$.

Woods, H., 1904-13, A monograph of the Cretaceous Lamellibranchia of England: London, Palaeontographical Society, v. 2, 473 p., 67 pls. 


\section{LOCALITY INFORMATION FOR FOSSIL LOCATIONS MENTIONED IN TEXT AND TABLE 1}


USGS Mesozoic locality: M5368

Field identifier: 69-JLP-1

Collector: D.L. Jones

Loma Prieta Road

Latitude: $37^{\circ} 5.95^{\prime} \mathrm{N}$.

Longitude: $121^{\circ} 51.44^{\prime} \mathrm{W}$.

Elevation: $2,950 \mathrm{ft}(899 \mathrm{~m})$

Township: $10 \mathrm{~S}$.

Range: $1 \mathrm{E}$.

Section: $4, \mathrm{NE}^{1 / 4} \mathrm{NE}^{1 / 4}$

Santa Cruz County, California, Loma Prieta 71/2-min quadrangle

USGS Mesozoic locality: M5890

Field identifier: 71-LP-597

Collector: T. Simoni

Mt. Madonna Road north of Maymens Flat

Latitude: $37^{\circ} 5.15^{\prime} \mathrm{N}$.

Longitude: $121^{\circ} 49.27^{\prime} \mathrm{W}$.

Elevation: $2,940 \mathrm{ft}(896 \mathrm{~m})$

Township: $10 \mathrm{~S}$.

Range: $1 \mathrm{E}$.

Section: $2, \mathrm{SW}^{1 / 4} / 4 \mathrm{SE}^{1 / 4} \mathrm{SE}^{1 / 4}$

Santa Clara County, California, Loma Prieta 71/2-min quadrangle

USGS Mesozoic locality: M6781

Field identifier: 77-CB-1804

Collector: M.C. Blake

Uvas Creek at Swanson Canyon

Latitude: $37^{\circ} 05.20^{\prime} \mathrm{N}$.

Longitude: $121^{\circ} 47.50^{\prime} \mathrm{W}$.

Elevation: $1,000 \mathrm{ft}(305 \mathrm{~m})$

Township: $10 \mathrm{~S}$.

Range: 2 E.

Section: 6, NE1/4 SE1/4SW1/4

Santa Clara County, California, Loma Prieta 71/2-min quadrangle

USGS Mesozoic locality: M8524

Field identifier: 88-E-1

Collector: W.P. Elder

Northern side of Loma Prieta Road

Latitude: $37^{\circ} 05.95^{\prime} \mathrm{N}$.

Longitude: $121^{\circ} 51.45^{\prime} \mathrm{W}$.

Elevation: $2,950 \mathrm{ft}(899 \mathrm{~m})$

Santa Cruz County, California, Loma Prieta 71/2-min quadrangle

USGS Mesozoic locality: M8525

Field identifier: 88-E-2

Collector: W.P. Elder

Northern side of Loma Prieta Road

Latitude: $37^{\circ} 05.91^{\prime} \mathrm{N}$.

Longitude: $121^{\circ} 51.20^{\prime} \mathrm{W}$.

Elevation: $2,950 \mathrm{ft}(899 \mathrm{~m})$

Santa Clara County, California, Loma Prieta 71/2-min quadrangle

USGS Mesozoic locality: M8529

Field identifier: 88-E-5

Collector: W.P. Elder

Steep bank east of Loma Prieta

Latitude: $37^{\circ} 06.68^{\prime} \mathrm{N}$.

Longitude: $121^{\circ} 50.04^{\prime} \mathrm{W}$.

Elevation: $3,200 \mathrm{ft}(976 \mathrm{~m})$

Township: $9 \mathrm{~S}$.

Range: $1 \mathrm{E}$.

Section: $35, \mathrm{NW}^{1 / 4}$

Santa Clara County, California, Loma Prieta 71/2-min quadrangle
USGS Mesozoic locality: M8535

Field identifier: $88-\mathrm{E}-6$

Collector: W.P. Elder

Concretions in talus on northeastern side of road

Latitude: $37^{\circ} 06.58^{\prime} \mathrm{N}$.

Longitude: $121^{\circ} 50.04^{\prime} \mathrm{W}$.

Elevation: $2,940 \mathrm{ft}(896 \mathrm{~m})$

Township: $9 \mathrm{~S}$.

Range: $1 \mathrm{E}$.

Section: $35, \mathrm{NW}^{1 / 4}$

Santa Clara County, California, Loma Prieta 71/2-min quadrangle

USGS Mesozoic locality: M8539

Field identifier: $88-\mathrm{MSJ}-220$

Collector: R.J. McLaughlin

Concretion on southwestern side of road on ridgetop

Latitude: $37^{\circ} 06.66^{\prime} \mathrm{N}$.

Longitude: $121^{\circ} 49.99^{\prime} \mathrm{W}$.

Elevation: $3,240 \mathrm{ft}(988 \mathrm{~m})$

Township: $9 \mathrm{~S}$.

Range: $1 \mathrm{E}$.

Section: $35, \mathrm{SE}^{1 / 4} \mathrm{NW} 1 / 4 \mathrm{NW}^{1 / 4}$

Santa Clara County, California, Loma Prieta 71/2-min quadrangle

USGS Mesozoic locality: M8540

Field identifier: $88-$ MSJ-890

Collector: R.J. McLaughlin

Sandstone on southwestern side of Mt. Madonna Road

Latitude: $37^{\circ} 05.15^{\prime} \mathrm{N}$.

Longitude: $121^{\circ} 49.27^{\prime} \mathrm{W}$.

Elevation: $2,940 \mathrm{ft}(896 \mathrm{~m})$

Township: $10 \mathrm{~S}$.

Range: $1 \mathrm{E}$.

Section: 2, SWl1/4SE1/4SE1/4

Santa Clara County, California, Loma Prieta 71/2-min quadrangle

USGS Mesozoic locality: M8554

Field identifier: None

Collector: W.P. Elder

On intermittent creek crossing Loma Chiquita Road

Latitude: $37^{\circ} 06.65^{\prime} \mathrm{N}$.

Longitude: $121^{\circ} 50.10^{\prime} \mathrm{W}$.

Elevation: $3,000 \mathrm{ft}(915 \mathrm{~m})$

Township: $9 \mathrm{~S}$.

Range: 1 E.

Section: $35, \mathrm{SE}^{1 / 4 \mathrm{NW}^{1 / 4}} \mathrm{NW}^{1 / 4}$

Santa Clara County. California, Loma Prieta $7 \frac{1}{2} 2-$ min quadrangle

USGS Mesozoic locality: M8575

Field identifier: $89-\mathrm{E}-28$

Collector: W.P. Elder

Southern bank of Lake Elsman east of dam

Latitude: $37^{\circ} 07.79^{\prime} \mathrm{N}$.

Longitude: $121^{\circ} 55.73^{\prime} \mathrm{W}$.

Elevation: $1,200 \mathrm{ft}(366 \mathrm{~m})$

Township: $9 \mathrm{~S}$.

Range: $1 \mathrm{~W}$.

Section: $24, \mathrm{SW}^{1 / 4} \mathrm{SW} 1 / 4 \mathrm{SW}^{1 / 4}$

Santa Clara County, California, Los Gatos 71/2-min quadrangle

USGS Mesozoic locality: M8576

Field identifier: 89-E-29

Collector: W.P. Elder

Southern side of Williams Reservoir

Latitude: $37^{\circ} 07.17^{\prime} \mathrm{N}$.

Longitude: $121^{\circ} 54.22^{\prime} \mathrm{W}$.

Elevation: $1,400 \mathrm{ft}(427 \mathrm{~m})$

Santa Clara County, California, Laurel 71/2-min quadrangle 


\section{PLATES 1-5}

Contact photographs of the plates in this report are available, at cost, from the U.S. Geological Survey Photographic Library, Federal Center, Denver, CO 80225. 


\section{PLATE 1}

\section{Late Cretaceous Mollusks}

[All figures natural size and from U.S. Geological Survey (USGS) Mesozoic locality M8525 except as indicated. Localities shown in text fig. 1. All specimens are reposited in the U.S. Museum of Natural History (USNM), Washington, D.C.]

Figures 1, 5. Isognomon sp.

1. Latex cast of hinge and internal mold of right valve. USNM 444989.

5. Latex cast of hinge and internal mold of left valve. USNM 444990.

2, 7, 9. Barbatia sp.

2. Latex cast of hinge and internal mold of right valve. USNM 444991.

7. Internal mold of right valve. USNM 444992.

9. Latex cast of external mold of left valve. USNM $444993(\times 1.25)$.

3. Mytilus sp. cf. M. quadratus Gabb, 1869. Internal mold of left valve from USGS Mesozoic locality M8576 showing posterior adductor muscle scar on upper right. External mold shows ornament consisting of lamellar growth lines similar to those visible on internal mold. USNM 444994.

4, 6, 8. Lyriochlamys traskii (Gabb), 1864

4. Latex cast of external mold of a specimen having numerous squamose radial ribs; valve unknown. USNM 444995.

6. Latex cast of external mold of right valve having complete posterior and partial anterior auricle. USNM 444996.

8. Latex cast of right valve having complete anterior auricle. USNM $444997(\times 1.5)$.

10. Inoceramus (Endocostea?) sp. aff. I. (E.?) cymbaeformis Pergament, 1974. Internal mold of right valve. USNM 444998 $(\times 0.75)$. 

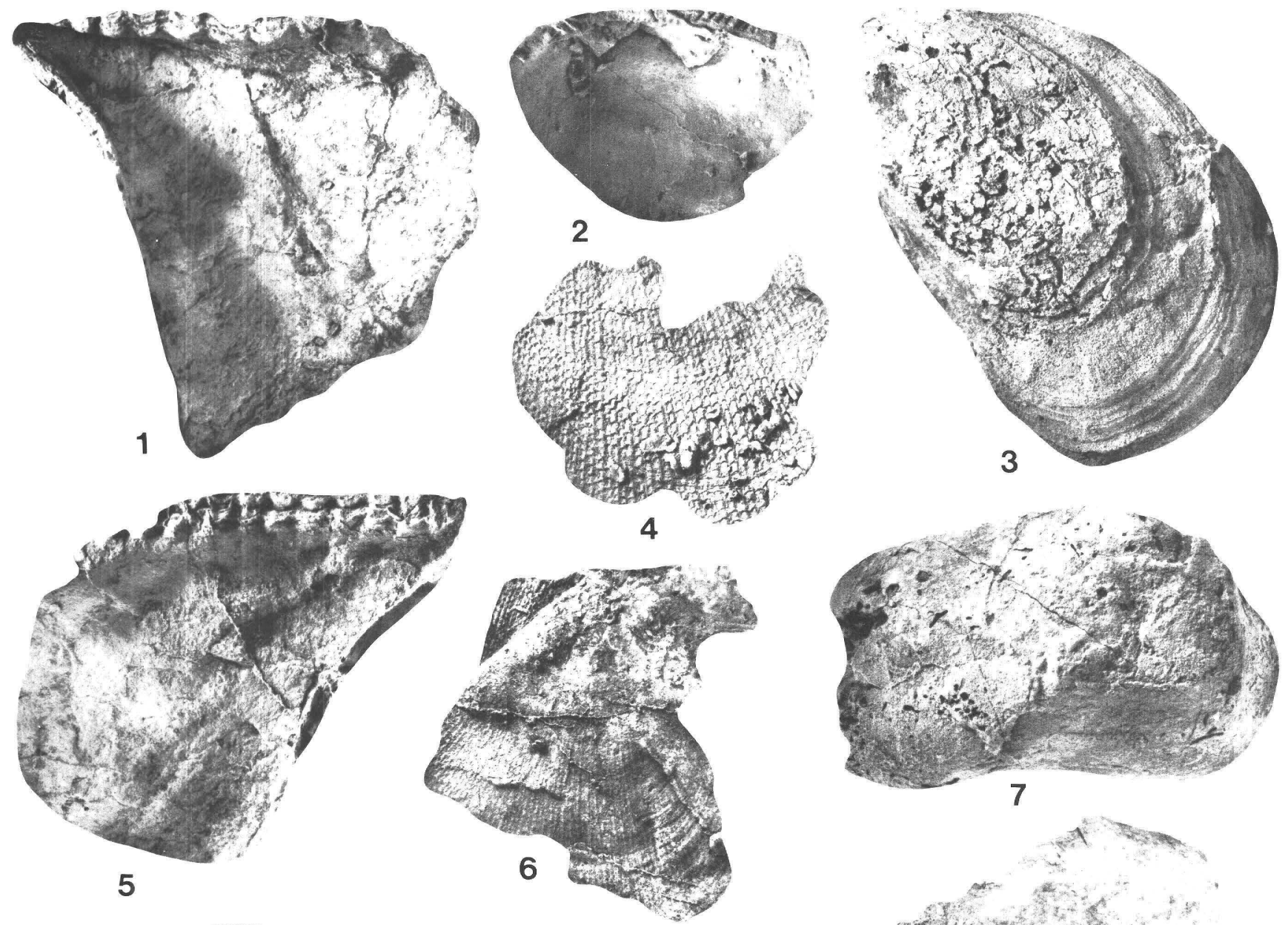

5
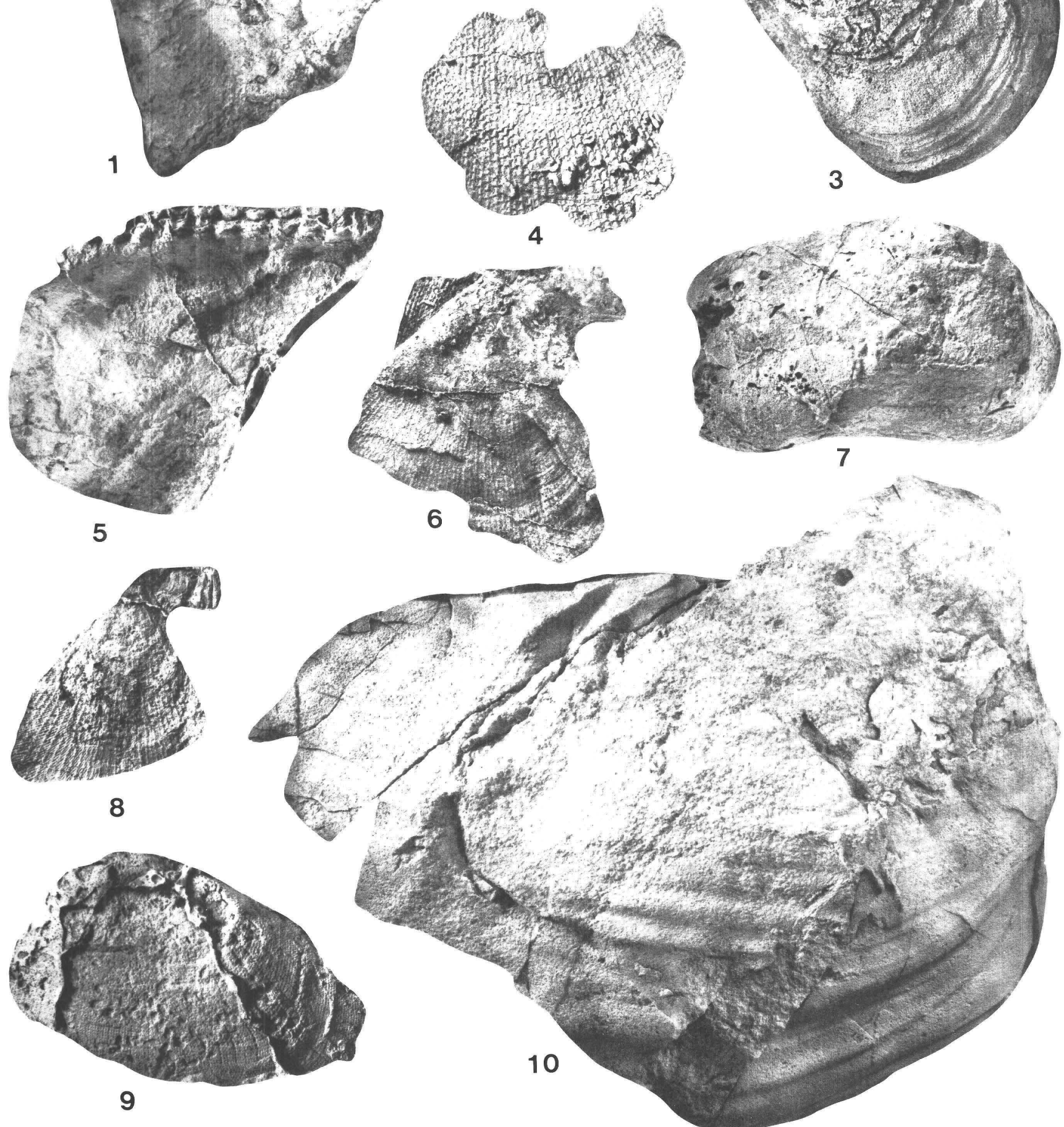

LATE CRETACEOUS MOLLUSKS 


\section{PLATE 2}

\section{Late Cretaceous Mollusks}

[All figures natural size and from U.S. Geological Survey (USGS) Mesozoic locality M8525 except as indicated. Localities shown in text fig. 1. All specimens are reposited in the U.S. Museum of Natural History (USNM), Washington, D.C.]

Figures 1-4. Spondylus subnodosus (Packard), 1922

1. Latex cast of hinge and internal mold of left valve. USNM 444999.

2. Latex cast of composite internal-external mold of left valve. USNM 445000.

3. Latex cast of partial external mold of left valve(?). Primary ribs showing small nodes and secondary radiating ribs are evident. USNM $445001(\times 1.5)$.

4. Latex cast of external mold of left valve showing primary and secondary ribs and small nodes. USNM 445002 $(\times 1.5)$.

5, 8-10. Lyriochlamys traskii (Gabb), 1864

5. Latex cast of external mold of partial left valve of juvenile from USGS Mesozoic locality M8576. USNM 445003 $(\times 2)$.

8. Latex cast of external mold of unknown partial valve of juvenile. USNM $445004(\times 2)$.

9. Latex cast of external mold of unknown partial valve of adult showing squamose radial ribs and divaricate ribs in interspaces. USNM $445005(\times 2)$.

10. Latex cast of external mold of unknown partial valve showing squamose radial ribs and divaricate ribs in interspaces and lamellar growth lines. USNM $445006(\times 1.5)$.

6, 7, 11. Inoceramus (Endocostea?) sp. aff. I. (E.?) cymbaeformis Pergament, 1974.

6. Dorsal view of latex cast of internal mold of right valve. USNM $445007(\times 0.75)$.

7. Posterior view of latex cast of internal mold of right valve showing flexure of posterior margin. USNM 445007 $(\times 0.75)$.

11. Latex cast of internal mold of right valve. USNM $445007(\times 0.75)$. 

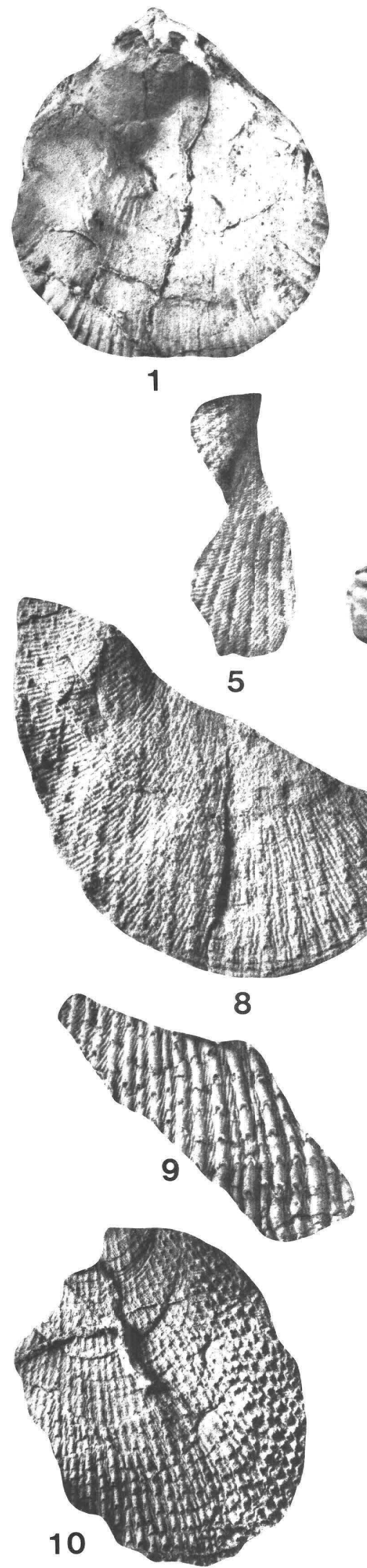
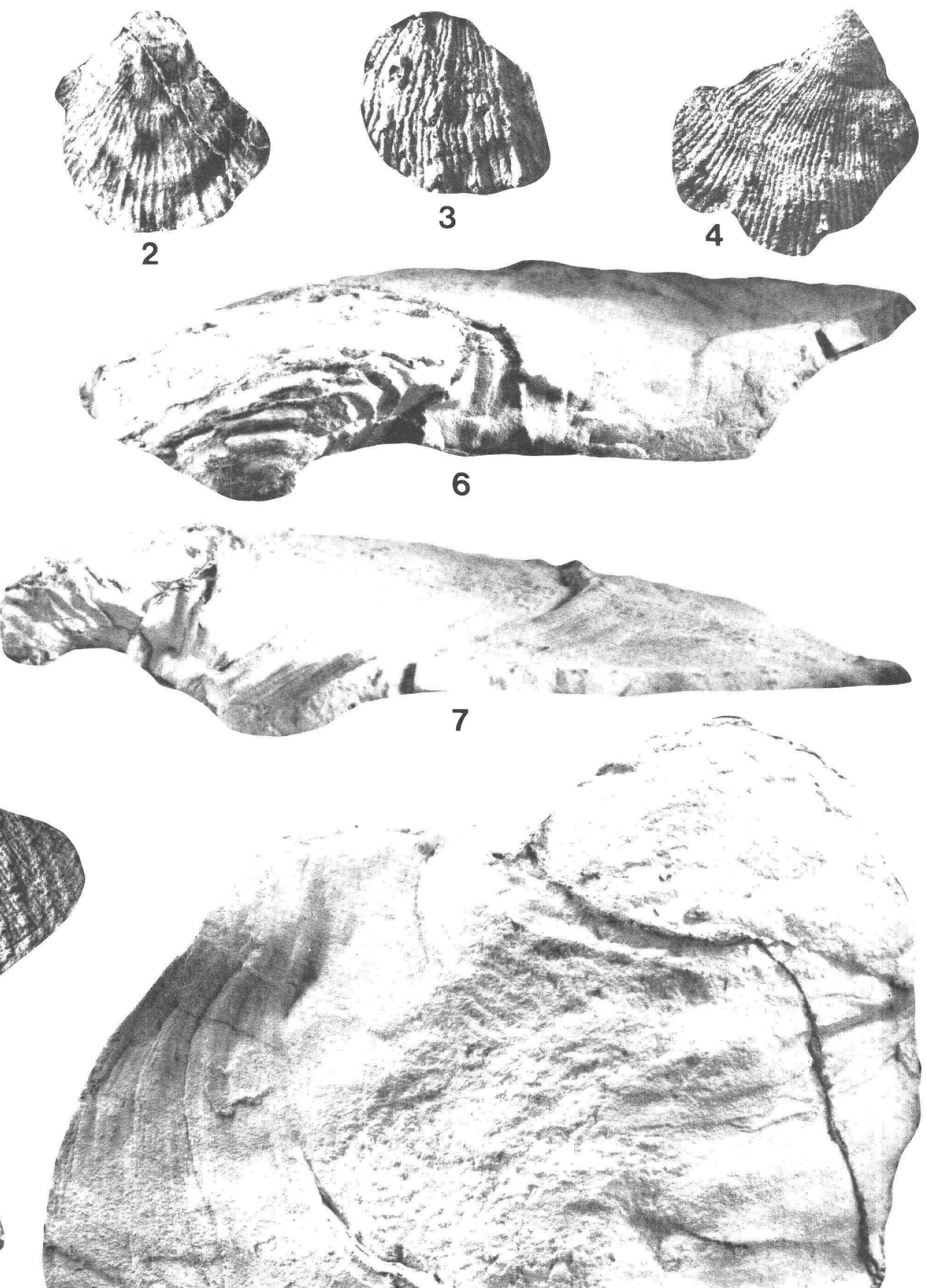


\section{PLATE 3}

\section{Late Cretaceous Mollusks}

[All figures natural size and from U.S. Geological Survey (USGS) Mesozoic locality M8525 except as indicated. Localities shown in text fig. 1. All specimens are reposited in the U.S. Museum of Natural History (USNM), Washington, D.C.]

Figures $1-4,7,11,12$. Acesta n.sp. A

1. Latex cast of hinge and internal mold of left valve showing oblique, posteriorly located resilifer. USNM 445008.

2. Latex cast of external mold of left valve. USNM 445008.

3. Latex cast of external mold of left valve. USNM 445009.

4. Latex cast of external mold of right valve showing squamose ribbing on adult. USNM 445010 .

7. Latex cast of external mold of left valve showing squamose ribbing on adult and deformation of posterior side, probably reflecting contact with a foreign object during growth. USNM 445011.

11. Latex cast of external mold of left valve from USGS Mesozoic locality M8576 showing elongate anterior auricle and anterior sulcus. USNM 445012.

12. Latex cast of external mold of posterior portion of left valve of a large specimen. Note flange around posterior margin. USNM 445013.

5, 9. Lima n.sp. A

5. Latex cast of external mold of right valve from USGS Mesozoic locality M8576. USNM $445014(\times 2)$.

9. Latex cast of external mold of right valve from USGS Mesozoic locality M8576. USNM $445015(\times 2)$.

6, 10. Amphidonte (Amphidonte) parasitica (Gabb), 1864

6. Latex cast of external mold of juvenile right valve. USNM $445016(\times 2)$.

10. Exterior of right valve. Note faint radial striae on posterioventral surface. USNM 445017.

8, 13. Spondylus subnodosus (Packard), 1922

8. Latex cast of external mold of left valve. USNM 445018.

13. Latex cast of external mold of two left valves from USGS Mesozoic locality M8576. USNM 445019. 

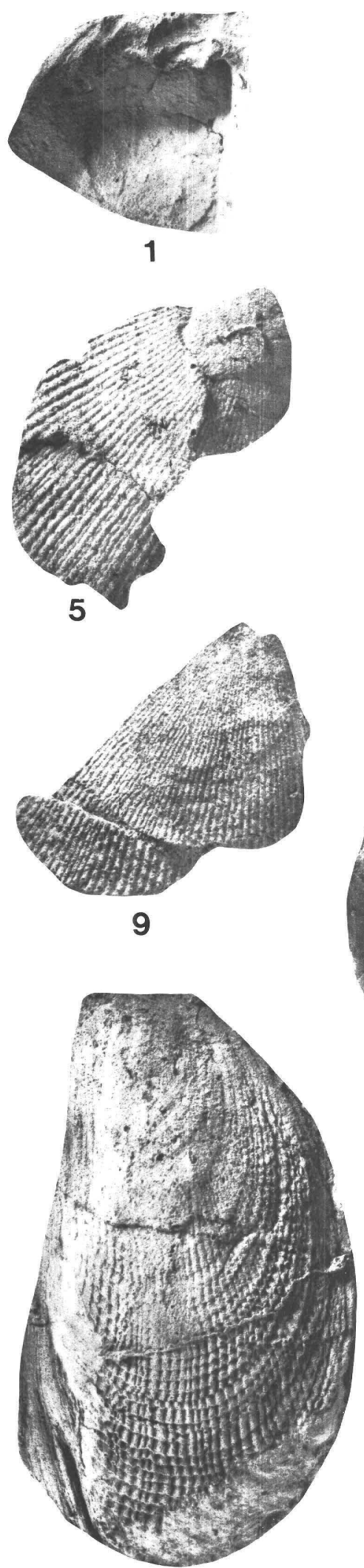

11
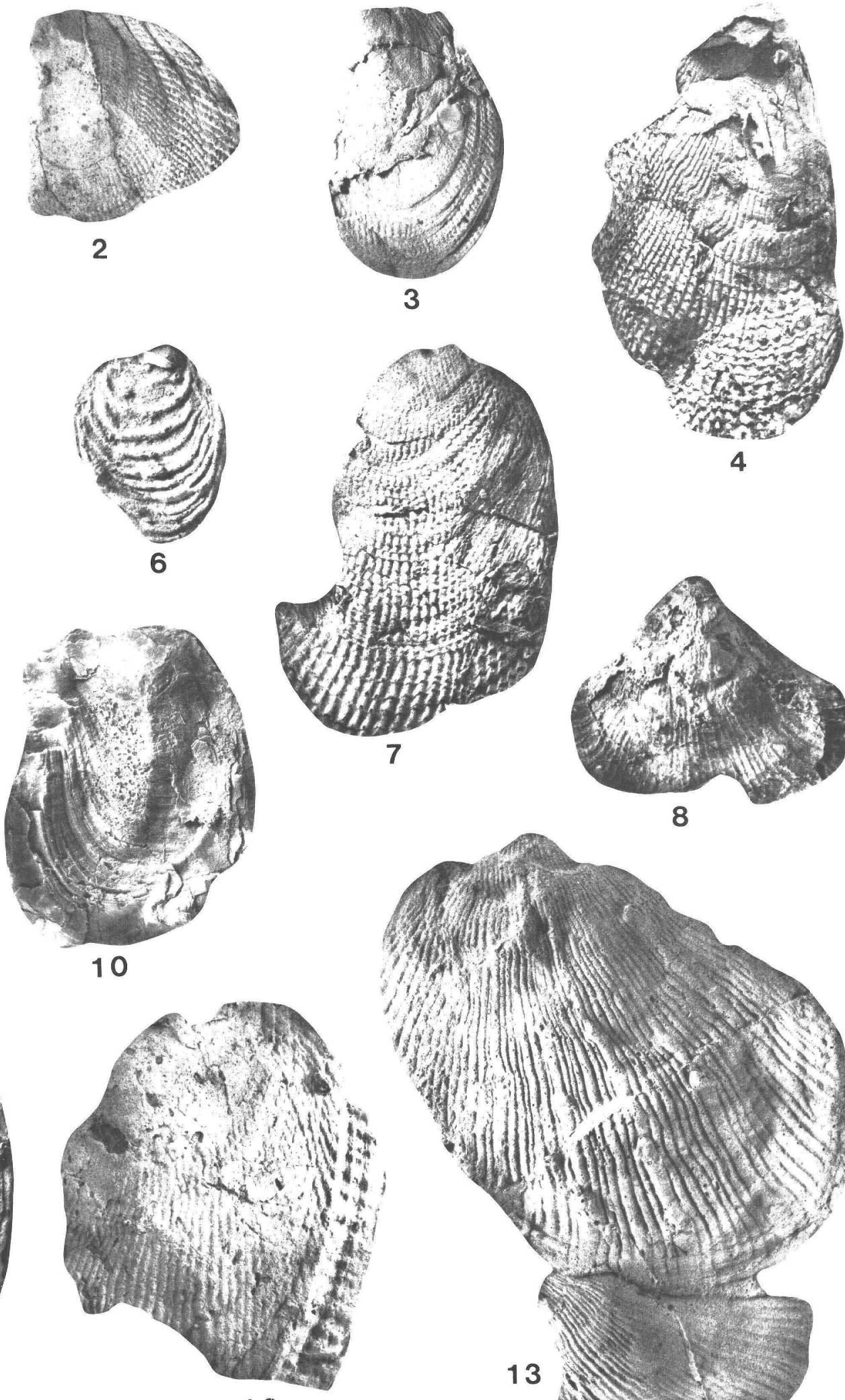

12
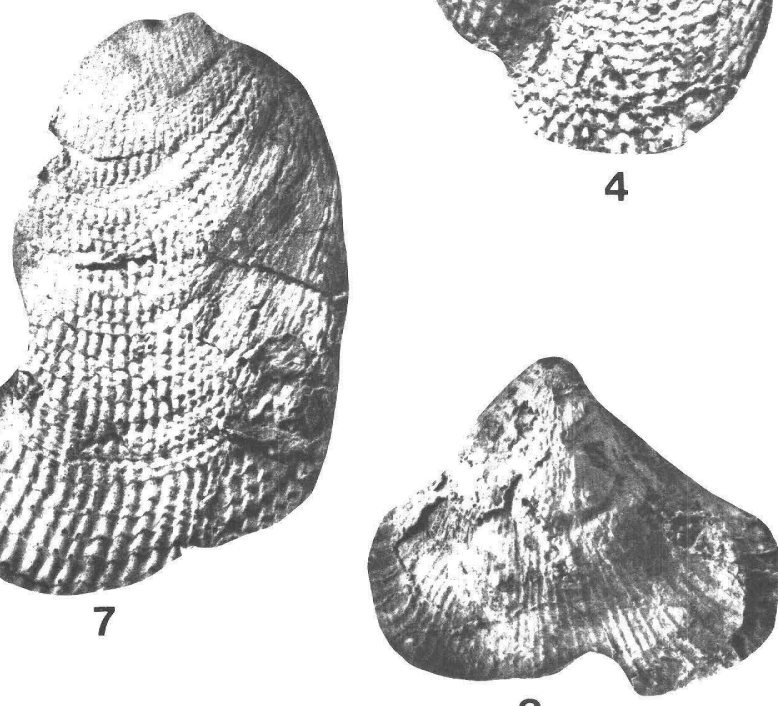

8

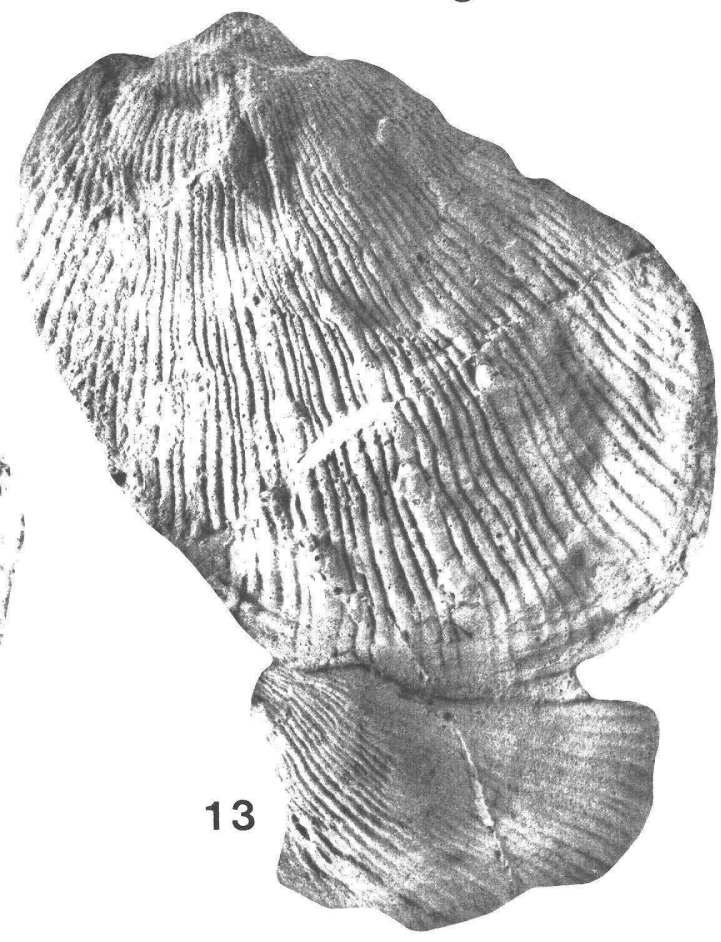

LATE CRETACEOUS MOLLUSKS 


\section{PLATE 4}

\section{Late Cretaceous Invertebrates}

[All figures natural size and from U.S. Geological Survey (USGS) Mesozoic locality M8525 except as indicated. Localities shown in text fig. 1. All specimens are reposited in the U.S. Museum of Natural History (USNM), Washington, D.C.]

Figures 1-3. Cidaroid echinoid spines

1. Latex cast of external mold of basal part of spine. USNM $445020(\times 2)$.

2. Latex cast of external mold of midportion of spine. USNM $445021(\times 1.5)$.

3. Latex cast of external mold of spine near apex. USNM $445022(\times 2)$.

4, 5. Patellacean gastropod

4. Top view of latex cast of external mold from USGS Mesozoic locality M8576. USNM $445023(\times 2)$.

5. Side view of latex cast of external mold from USGS Mesozoic locality M8576. USNM $445023(\times 2)$.

6. Callianassa? sp. Latex cast of external mold of manus. USNM $445024(\times 2)$.

7, 8. Hipponix dichotomus (Gabb), 1864

7. Top view of internal mold from USGS Mesozoic locality M8576. Fragmented external mold shows ornament like that developed on figured internal mold. USNM $445025(\times 2)$.

8. Side view of internal mold from USGS Mesozoic locality M8576. Fragmented external mold shows ornament like that developed on figured internal mold. USNM $445025(\times 2)$.

9, 17-23. Amphidonte (Amphidonte) parasitica (Gabb), 1864

9. Top view of left valve of elongate morphotype. USNM 445026.

17. Top view of left valve of ovate morphotype. USNM 445027.

18. Anteroventral view of left valve of typical morphotype. USNM 445028.

19. Anterior view of left valve of typical morphotype. USNM 445029.

20. Anterior view of left valve of ovate morphotype having a carinate umbilical ridge. USNM 445027.

21. Internal mold of left valve of ovate morphotype showing adductor muscle scar and chomata along anterior and ventral margins. USNM 445030.

22. Bottom view of left valve of typical morphotype. USNM 445028.

23. Bottom view of left valve of typical morphotype. USNM 445029.

10. Crassatella sp. cf. C. conradiana (Gabb), 1864. Latex cast of hinge and internal mold. USNM 445031.

11-15. Calcispongea

11. Latex cast of external mold of ramous morphotype from USGS Mesozoic locality M8576. USNM $445032(\times 2)$.

12. Latex cast of external mold of ramous morphotype. USNM $445033(\times 2)$.

13. Latex cast of external mold of ramous morphotype from USGS Mesozoic locality M8576. Note acrothoracian barnacle borings on upper third of specimen. USNM 445034.

14. Latex cast of external mold of encrusting morphotype. USNM $445035(\times 1.5)$.

15. Replaced branch of flabellate morphotype. USNM 445036.

16. External mold of encrusting Cheilostome bryozoan. USNM $445037(\times 2)$. 

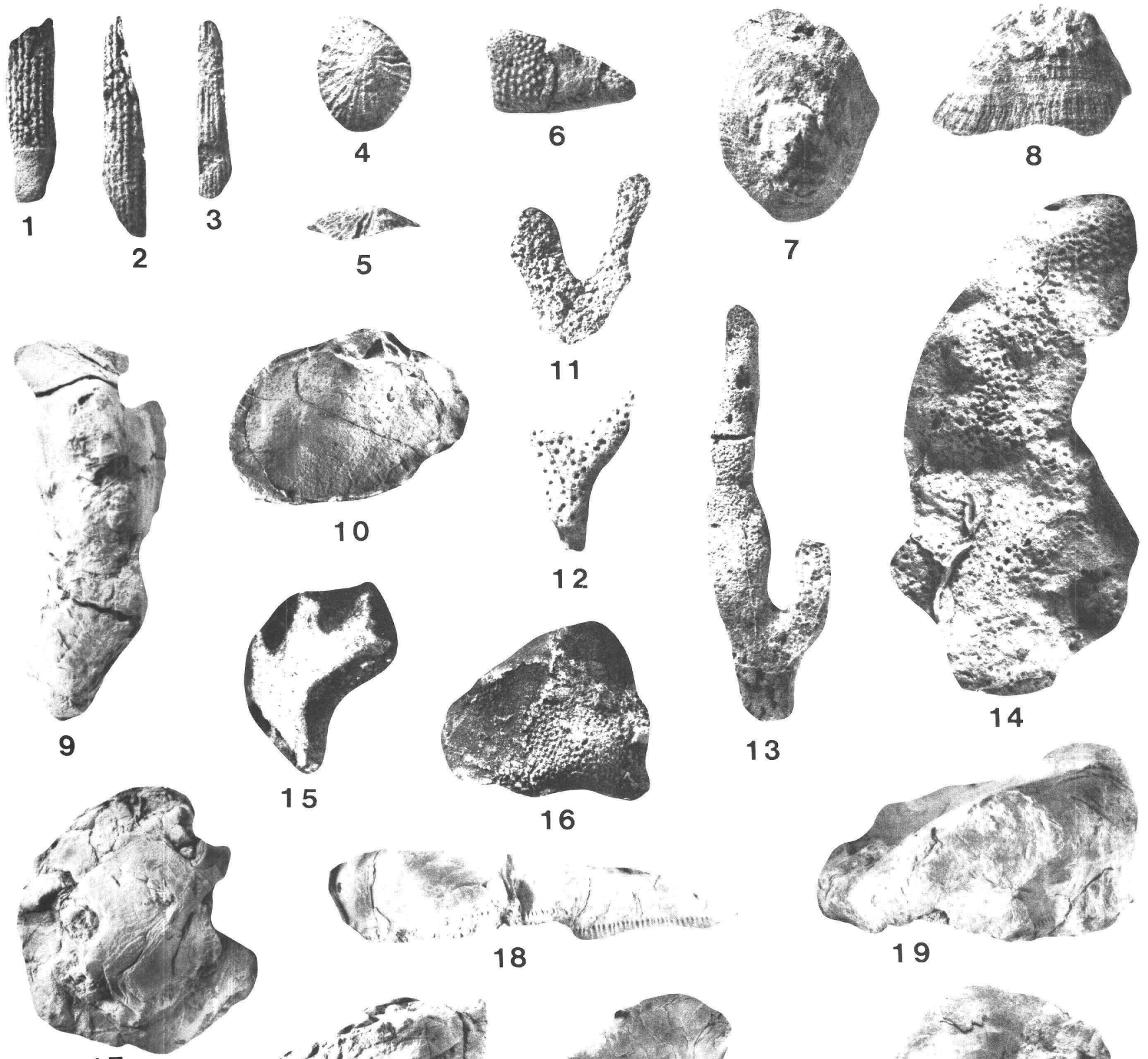

15

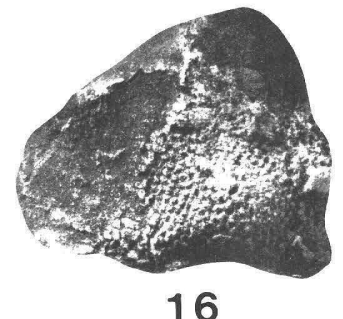

13

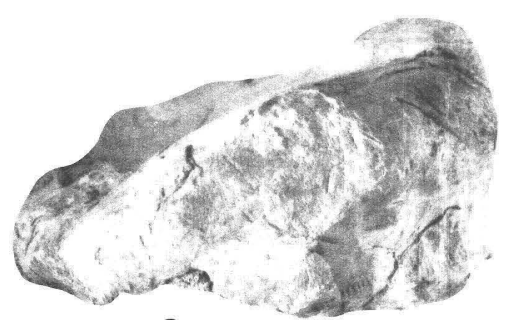

18

19
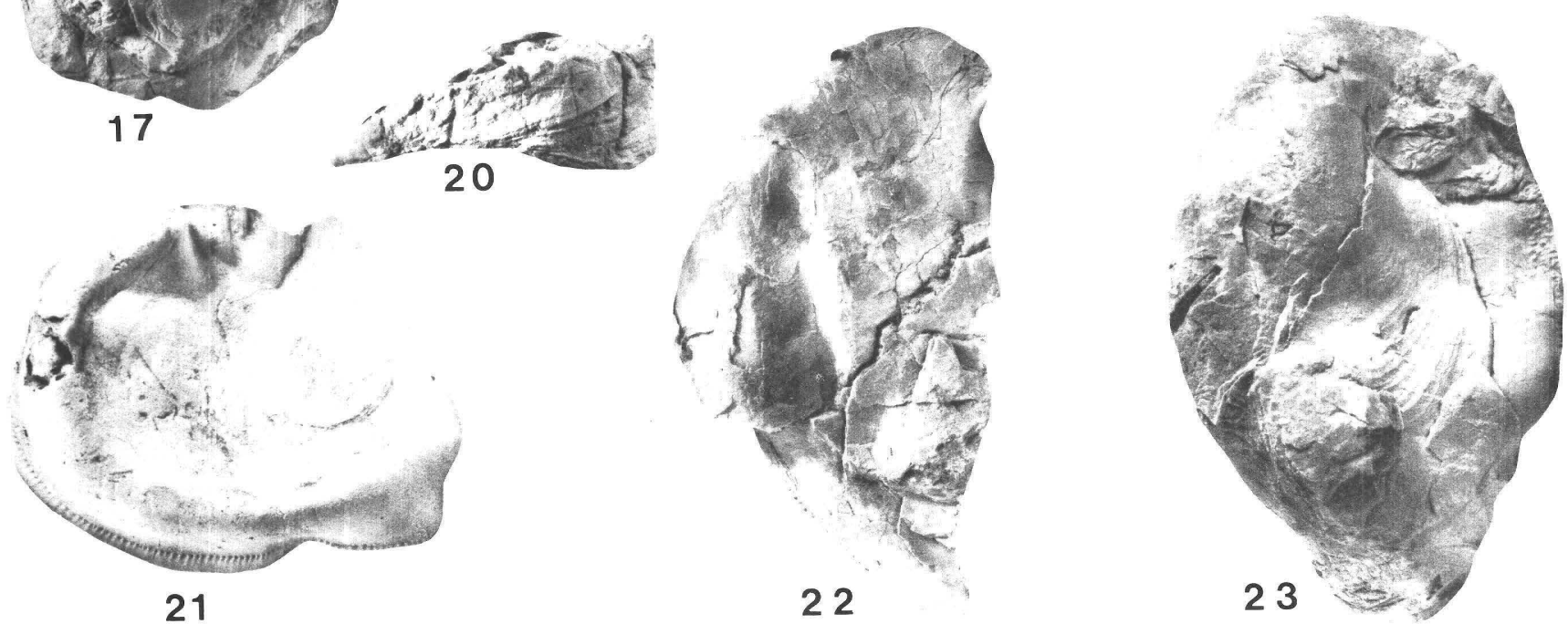


\section{PLATE 5}

\section{Late Cretaceous Coral and Ichnofossils}

[All figures natural size and from U.S. Geological Survey (USGS) Mesozoic locality M8525 except as indicated. Localities shown in text fig. 1. All specimens are reposited in the U.S. Museum of Natural History (USNM), Washington, D.C.]

Figures 1, 2. Astrangiidae? sp.

1. Latex cast of external mold. USNM $445038(\times 2)$.

2. Latex cast of external mold. USNM $445039(\times 2)$.

3. Sandstone casts of borings, of possible algal origin, in void produced by dissolution of a shell fragment. USNM 445040 $(\times 3)$.

4. Rasplike trace of possible isopod or gastropod origin on internal mold of Spondylus shell. USNM $445041(\times 3)$.

5. Sandstone cast of large arcuate borings having oblique constrictions. Bored substrate is unknown (possibly wood or a Spondylus shell fragment). Borings may have been produced by bivalves. USNM 445042.

6. Sandstone casts of borings on internal mold of Amphidonte. Borings probably produced by early stage of clionid sponge boring activity. USNM $445043(\times 2)$.

7. Spirorbis-like serpulid worm tube encrusting a mytilid shell fragment from USGS Mesozoic locality M8576. USNM $445044(\times 1.5)$.

8, 9. Ichnogenus Gastrochaenolites?

8. Sandstone mold of sac-shaped boring having oblique constrictions. Bored substrate unknown (see pl. 5, fig. 9 caption). USNM $445045(\times 2)$.

9. Sandstone mold of sac-shaped boring having oblique constrictions. USNM $445045(\times 2)$. Bored substrate unknown, but the presence of Entobia borings (USNM 445058) at the lower right indicates a carbonate substrate. Tubular boring in foreground also has oblique constrictions and resembles borings illustrated in plate 5, figure 5.

10, 12, 16. Ichnogenus Maeandropolydora?

10. Sandstone cast of meandering borings on mold of Amphidonte shell. USNM 445046.

12. Sandstone cast of arcuate to meandering borings on mold of Amphidonte shell. USNM 445047.

16. Sandstone cast of arcuate borings on mold of Amphidonte shell. USNM 445054.

11. Latex cast of dendritic pattern of unknown origin (possibly bryozoan) present on external mold of unknown shell fragment from USGS Mesozoic locality M8576. USNM 445048. Also note Spirobis-like worm tube at top of fragment. USNM 445049 .

13, 14, 18. Ichnogenus Entobia

13. Sandstone cast of borings in dissolution void of unknown shell. Entobia reflecting middle stages of clionid sponge boring activity. USNM 445050. Also note several acrothoracian barnacle borings (Rogerella) at right center. USNM 445051.

14. Sandstone cast of borings in dissolution void of Spondylus shell. Entobia reflecting late stages of clionid sponge boring activity. USNM 445052.

18. Sandstone cast of borings in dissolution void of Lyriochlamys shell. Entobia reflecting early to middle stages of clionid sponge boring activity. USNM $445053(\times 2)$.

15, 17. Ichnogenus Rogerella

15. Sandstone cast of acrothoracian barnacle borings on external mold of unknown shell from USGS Mesozoic locality M8576. USNM $445055(\times 2)$.

17. Sandstone cast of acrothoracian barnacle borings on external mold of unknown shell. USNM 445056. Also note small branching tubular burrows of possible clionid origin at upper right. USNM $445057(\times 2)$. 

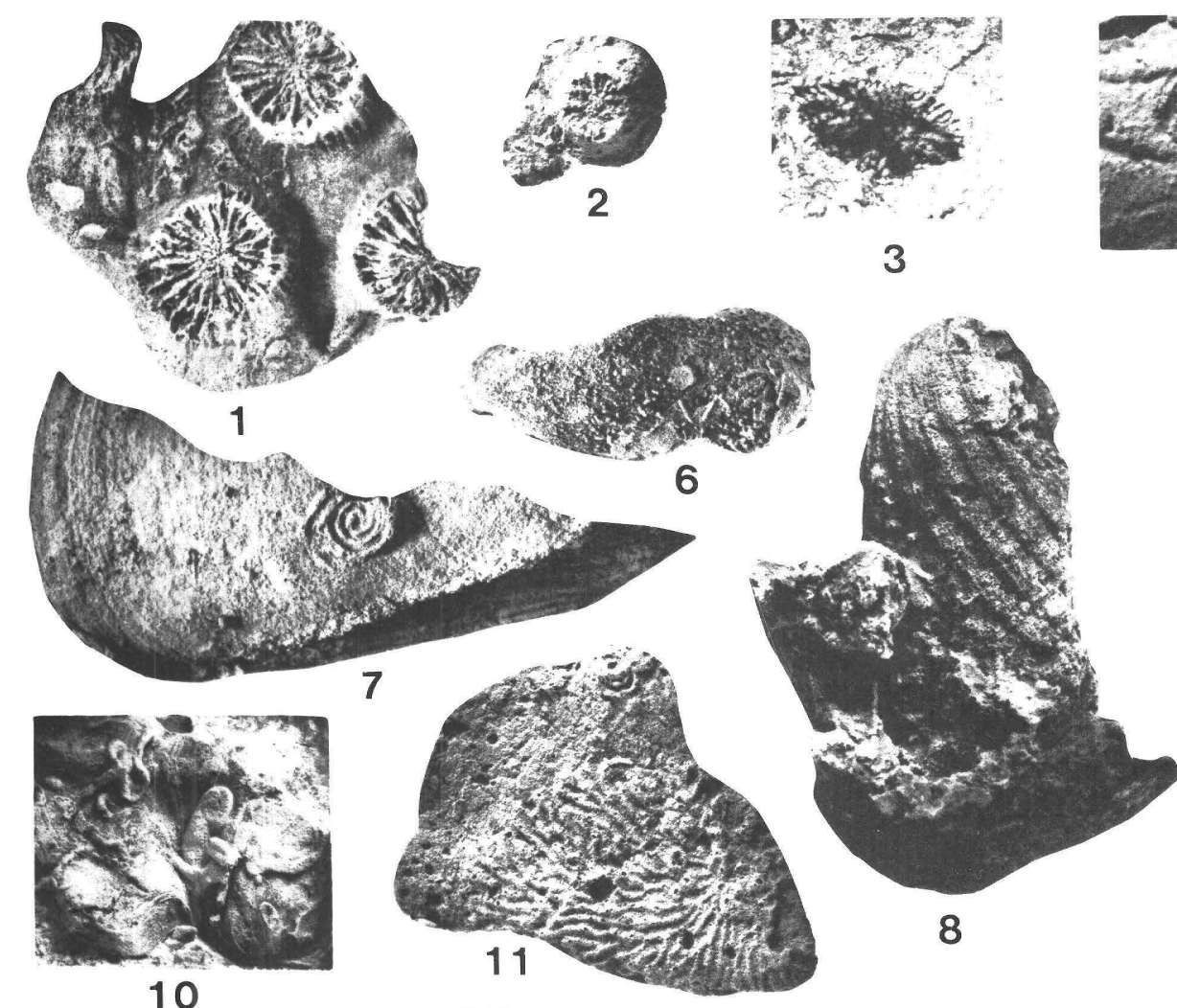

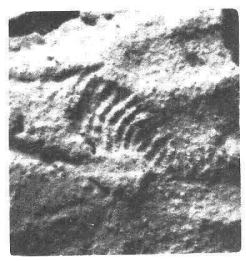

4

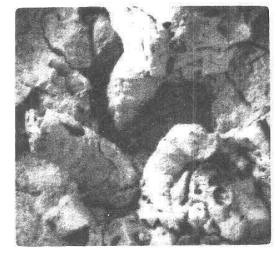

5

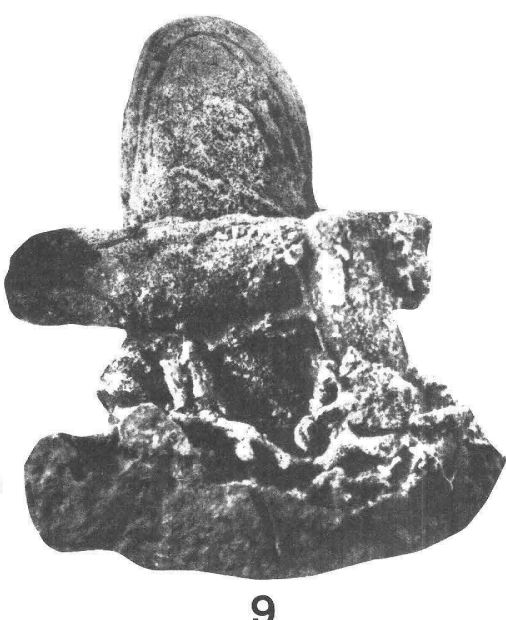

9

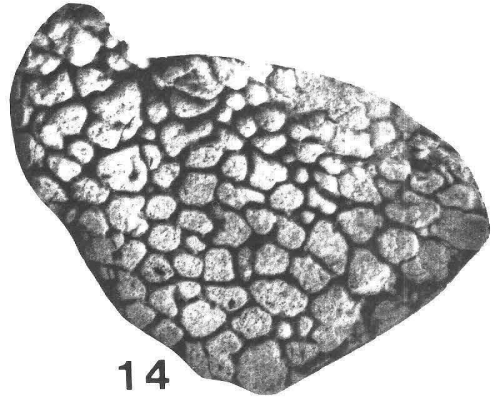

13
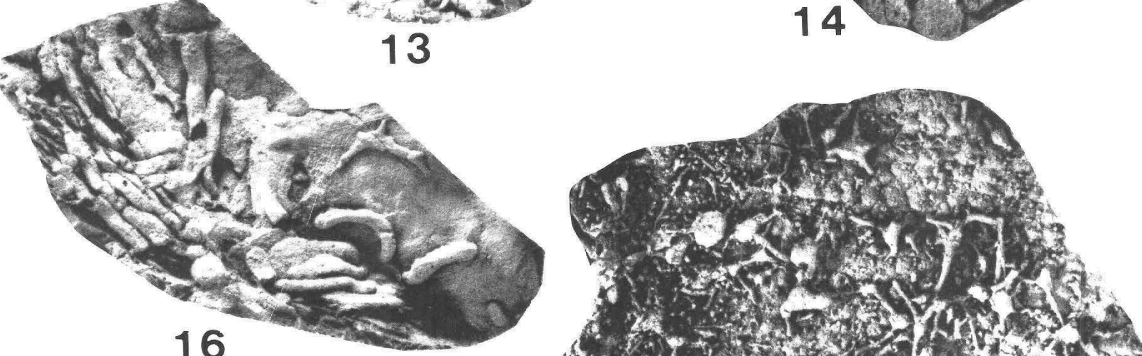

d.
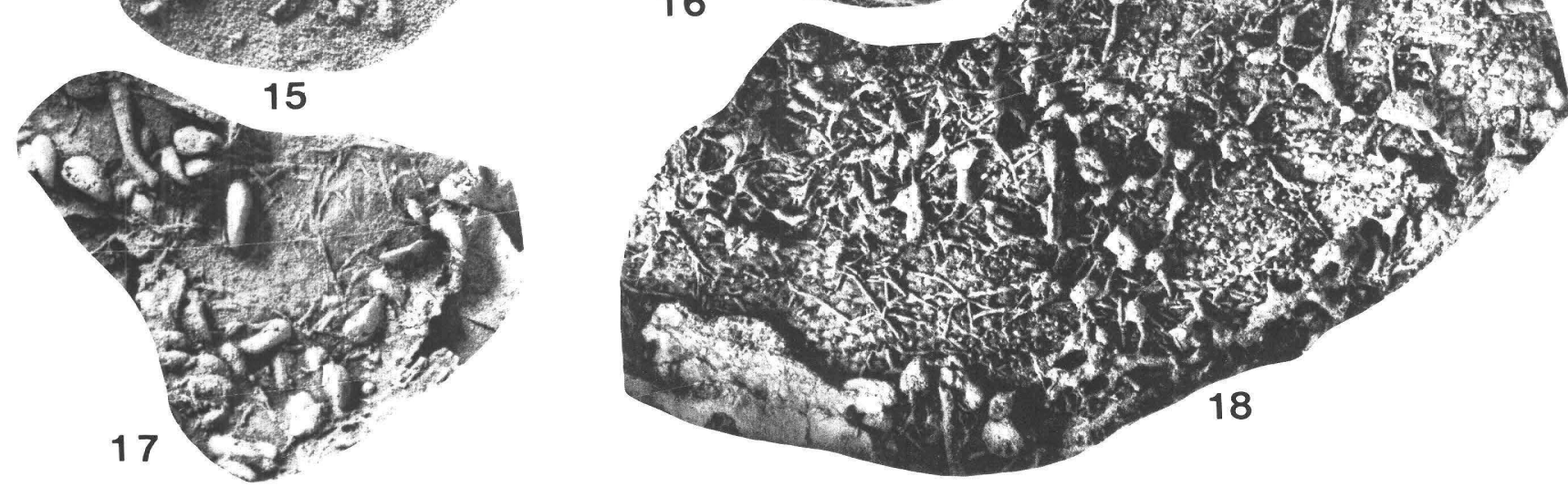

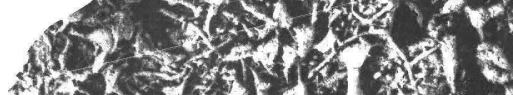

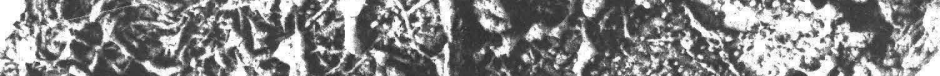

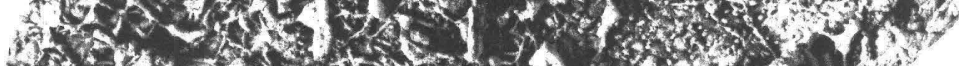

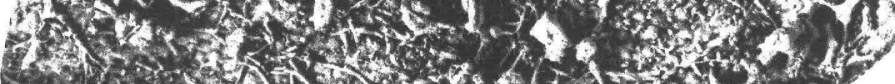

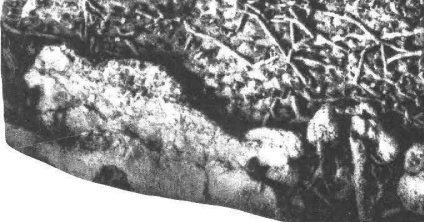

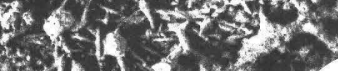





\section{AVAILABILITY OF BOOKS AND MAPS OF THE U.S. GEOLOGICAL SURVEY}

Instructions on ordering publications of the U.S. Geological Survey, along with prices of the last offerings, are given in the current-year issues of the monthly catalog "New Publications of the U.S. Geological Survey." Prices of available U.S. Geological Survey publications released prior to the current year are listed in the most recent annual "Price and Availability List." Publications that are listed in various U.S. Geological Survey catalogs (see back inside cover) but not listed in the most recent annual "Price and Availability List" are no longer available.

Prices of reports released to the open files are given in the listing "U.S. Geological Survey Open-File Reports," updated monthly, which is for sale in microfiche from the U.S. Geological Survey, Books and Open-File Reports Section, Federal Center, Box 25425, Denver, CO 80225. Reports released through the NTIS may be obtained by writing to the National Technical Information Service, U.S. Department of Commerce, Springfield, VA 22161; please include NTIS report number with inquiry.

Order U.S. Geological Survey publications by mail or over the counter from the offices given below.

\section{BY MAIL}

\section{Books}

Professional Papers, Bulletins, Water-Supply Papers, Techniques of Water-Resources Investigations, Circulars, publications of general interest (such as leaflets, pamphlets, booklets), single copies of Earthquakes \& Volcanoes, Preliminary Determination of Epicenters, and some miscellaneous reports, including some of the foregoing series that have gone out of print at the Superintendent of Documents, are obtainable by mail from

\section{U.S. Geological Survey, Books and Open-File Reports Federal Center, Box 25425 Denver, CO 80225}

Subscriptions to periodicals (Earthquakes \& Volcanoes and Preliminary Determination of Epicenters) can be obtained ONLY from the

\section{Superintendent of Documents \\ Government Printing Office \\ Washington, D.C. 20402} Documents.)

(Check or money order must be payable to Superintendent of

\section{Maps}

For maps, address mail orders to

$$
\begin{gathered}
\text { U.S. Geological Survey, Map Distribution } \\
\text { Federal Center, Box } 25286 \\
\text { Denver, CO } 80225
\end{gathered}
$$

Residents of Alaska may order maps from

\author{
Alaska Distribution Section, U.S. Geological Survey \\ New Federal Building - Box 12 \\ 101 Twelfth Ave., Fairbanks, AK 99701
}

\section{OVER THE COUNTER}

\section{Books}

Books of the U.S. Geological Survey are available over the counter at the following U.S. Geological Survey Public Inquiries Offices, all of which are authorized agents of the Superintendent of Documents:

- WASHINGTON, D.C.-Main Interior Bldg., 2600 corridor, 18th and C Sts., NW.

- DENVER, Colorado-Federal Bldg., Rm. 169, 1961 Stout St.

- LOS ANGELES, California-Federal Bldg., Rm. 7638, $300 \mathrm{~N}$. Los Angeles St.

- MENLO PARK, California-Bldg. 3 (Stop 533), Rm. 3128, 345 Middlefield Rd.

- RESTON, Virginia-503 National Center, Rm. 1C402, 12201 Sunrise Valley Dr.

- SALT LAKE CITY, Utah-Federal Bldg., Rm. 8105, 125 South State St.

- SAN FRANCISCO, California-Customhouse, Rm. 504, 555 Battery St.

- SPOKANE, Washington-U.S. Courthouse, Rm. 678, West 920 Riverside Ave.

- ANCHORAGE, Alaska-Rm. 101, 4230 University Dr.

- ANCHORAGE, Alaska-Federal Bldg., Rm. E-146, 701 C St.

\section{Maps}

Maps may be purchased over the counter at the U.S. Geological Survey offices where books are sold (all addresses in above list) and at the following U.S. Geological Survey offices:

- ROLLA, Missouri-1400 Independence Rd.

- DENVER, Colorado-Map Distribution, Bldg. 810, Federal Center

- FAIRBANKS, Alaska-New Federal Bldg., 101 Twelfth Ave. 
